\title{
AVALIAÇÃO DA PRODUTIVIDADE E OUTROS CARACTERES EM DUAS POPULAÇŌES (BRANCA E AMARELA) DE MILHO (Za mays L.) SEPARADAS DO DENTADO COMPOSTO
}

\author{
PETER WEIGEL
}

Engenheiro Agrônomo

Orientador: JOÃO RUBENS ZINSLY

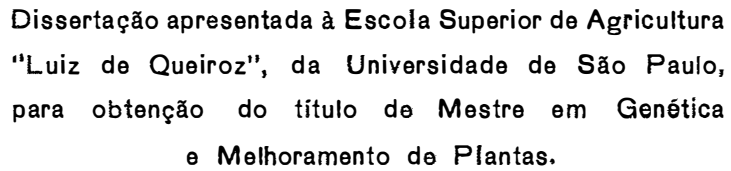

$P|R A C| C A B A$

Estado de São Paulo - Brasil

Maio - 1978 


\section{BIOGRAFIA DO AUTOR}

PETER WEIGEL, fitho de Frederico Weigel e Hitdegard Weigel, nasceu na cidade de são Paulo, Estado de são Pauzo, aos 4 dias do mês dé fevereirro do ano de 1952. Em 1971, ingressou na Escold superior do Agri cultura "Luiz de Queiroz" (ESALQ), na cidade de Piracicaba, Estado de São Paulo, obtend o aiploma de Engenheiro Agrônomo em dezembro de 19 ? 5 . Estagiou no Instituto de Genética da ESALQ, na área de me tho ramento de mitho, de maio de 1975 a fevereiro de 1976. Em margo de 1976 ingressou no Curso de Pös-Graduasão em "Genética e Melhoramento de Plantas". 
- Ao Prof. Dr. João Rubens Zinsly, que me iniciou no melhoramento e me orientou nesse trabalho.

- Ao Prof. Dr. José Branco de Miranda Filho, pelas sugestões e auxílio recebidos durante a anālise estatística dos dados.

- À Professora Dra. Maria Ruth B. AZZeoni, pela orientação durante a determinação das características radiculares.

- Ao Prof. Dr. Julio Marcos Filho e ao Engenheiro Agrô nomo Walter Rodrigues da Silva, do Departamento de Agricultura e Horticultura, Setor de Tecnologia de Sementes, por terem colocado ao meu dispor os materiais e a aparelhagem do setor e pela orientação recebida durante a realização dos testes de vigor de sementes.

- Aos Engenheiros Agrônomos Antonio Carlos da Sizva, Fernando Ajudarte Neto, Joaquim Aparecido Machado e Manoel Xavier dos Santos, pela ajuda recebida nos trabalhos de campo.

- Aos funcionários do Instituto de Genética, especialmente a Walter Pedro Pompermayer, Antonio Serrano, 
iii.

José Broglio e Erica Spruck, pela gentileza e pelo auxilio recebido sempre que solicitado.

- Ao Conselho Nacional de Pesquisas (CNPq) pela bolsa concedida a qual possibilitou a realização do presen te trabalho. 


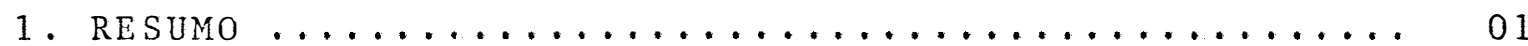

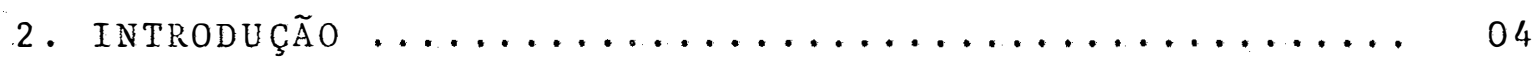

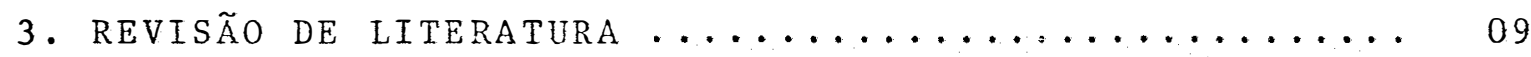

3.1. Relações entre a produção e caracteres morfoló-

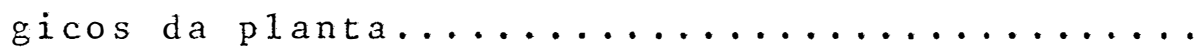

3.2. Relações entre a produção e caracteres da espi-

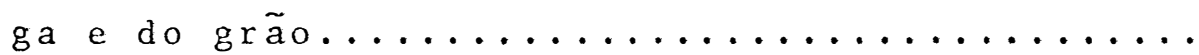

3.3. Relações entre caracteres morfolögicos da plan-

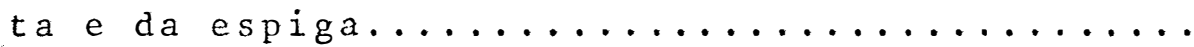

3.4. Relações entre caracteres do sistema radicular

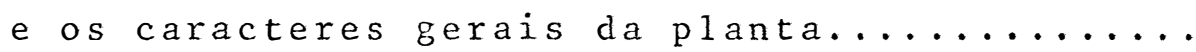

3.5. Vigor de sementes: conceitos e relações com o

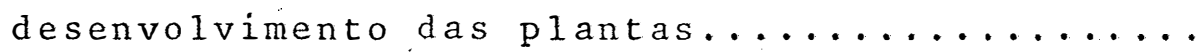

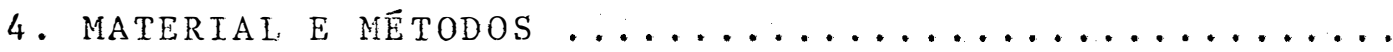

4.1. Ensaios de produção e determinações relacionadas. 4.1.1. Material.................... 39

4.1.2. Descrição dos tratamentos.......... 41

4.1.3. Metodologia................... 42

4.1.4. Anālise estatística................ 49

4.2. Determinação das características radiculares... 51

4.2.1. Material e Metodologia............ 51

4.2.2. Análise estatística............. 55

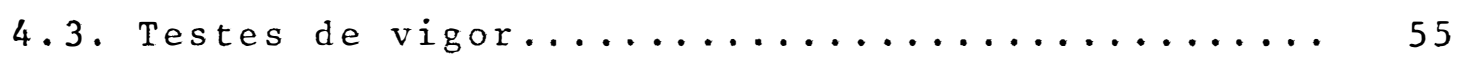

4.3.1. Teste padrão de germinação.......... 56

4.3.1.1. Material e metodologia...... 56

4.3.1.2. Anälise estatistica........ 57

4.3.2. Teste de emergência no campo......... 58

4.3.2.1. Material e metodologia...... 58 
Pägina

4.3.2.2. Anālise estatística....... 59

4.3.3. Teste de envelhecimento rápido....... 60

4.3.3.1. Material e metodologia....... 60

4.3 .3 .2 . Anāilse estatística........ 61

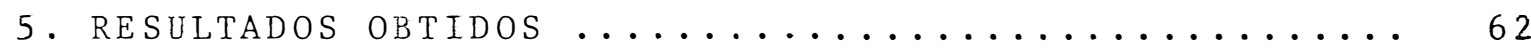

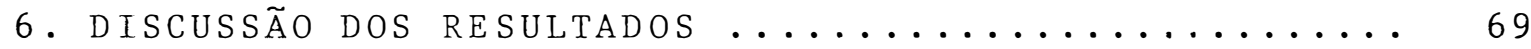

7. conclusões $\ldots \ldots \ldots \ldots \ldots \ldots \ldots \ldots \ldots \ldots \ldots \ldots \ldots \ldots \ldots$

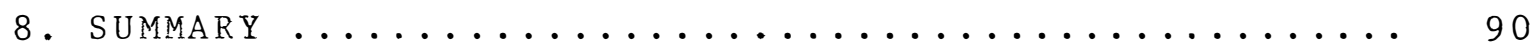

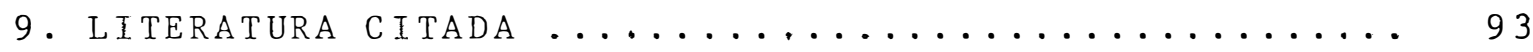

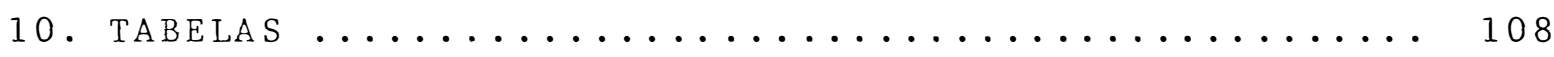




\section{RESUMO}

Este trabalho foi realizado para determinar se a coloração de sementes apresenta alguma influência sobre a ca pacidade produtiva de milhos brancos e amarelos originários de uma mesma população base. Procurou-se saber, também, a partir de uma série de caracteres determinados, quais poderiam estar contribuindo para a superioridade ou inferioridade produtiva das Populações Branca, Amarela e Intermediäria.

o trabalho foi dividido em três partes bāsicas: ensaios de produção e determinação de caracteres relacionados, testes de vigor e determinação de características radiculares. Os ensaios de produção e a determinação de caracteres relacionados foram conduzidos em dois anos consecutivos, sendo que os dois grupos restantes foram realizados apenas uma vez.

No primeiro grupo foram determinados os seguintes caracteres: produção, tipo de pendão, altura da planta, al tura da espiga, número de folhas por planta, número de espi- 
gas por planta, "stand", acamamento, nümero defileiras por es piga, nümero de grãos por fileira, tamanho da espiga, diâmetro da espiga, peso da espiga, peso do sabugo, peso de 100 grãos, número mëdio de grãos por espiga, produção mëdia por planta, nümero de espigas por parcela, peso médio do grão, com primento, 1 argura e espessura do grão.

Foram realizados os seguintes testes de vigor: teste padrão de germinação, teste de envelhecimento räpido e teste de emergência no campo. As características radiculares determinadas foram: peso total da planta aos 28 dias de idade, peso total de raízes, peso de raízes nodais, peso de raízes seminais, nūmero de raízes nodais, nūmero de raízes seminais, nūmero total de raízes e porcentagem de raízes seminais.

Analisando-se os dados obtidos concluiu-se, basicamente, o seguinte:

- Os ensaios de produção e as determinações de caracteres relacionados indicam uma tendência de superioridade da População Branca em relação às outras duas populações do composto. As características gerais da População Branca sugerem que esta desperdiça muita energia na formação do sabugo em detrimento da produção de grãos. A determinação do caráter nü mero de espigas por planta é mais correta quando feita em todas as plantas da parcela, ao invēs de 10 plantas competitivas escolhidas aleatoriamente. 
.03.

- A População Branca, entre as populações do composto, mostrou superioridade em todos os testes de vigor. Mostrou tendências de resistir melhor à deterioração causada por períodos longos de armazenamento. Determinou-se que o vigor só tem influência decisiva nos estägios iniciais de desen volvimento, não influindo em fases posteriores e na produção, em anos normais.

- A População Branca, até o 280 dia de idade, apresentou o sistema radicular mais pobre, entre as populações do composto, sendo que a População Intermediária apresentou os melhores resultados. Os dados obtidos sugerem que as características radiculares nas primeiras fases de desenvolvimento das plantas, tem pouca ou nenhuma influência sobre o comportamento das plantas na maturidade, não tendo tambëm relação como vigor de sementes. 


\section{INTRODUÇAO}

o milho (Zea mays L.) é uma planta altamente do I mesticada, tornando-se assim uma espécie inteiramente dependen te do homem, sem qualquer chance de sobreviver, isoladamente, na natureza. Em decorrência dos métodos de seleção artificial, seleção natural e cruzamentos naturais, o milho constitui uma espécie politípica, sendo conhecidas mais de 200 raças no continente americano. Com o passar dos anos, a pesquisa industrial foi descobrindo um nümero cada vez maior de modos de se aproveitar o milho, de maneira que atualmente é explorado economicamente para diferentes finalidades e se constitui numa grande fonte de produção de alimentos.

Os melhoristas tem desenvolvido muitas técnicas procurando aumentar a produção e melhorar a qualidade do mi1ho. O melhoramento por mutação, aproveitamento do vigor de híbrido, o desenvolvimento de delineamentos experimentais e análises, entre outros, constituem processos que tem demonstra do eficácia nos programas de melhoramento. No melhoramento, 
em geral, um dos objetivos primordiais હ a obtenção de genótipos com maior capacidade produtiva e que apresentem boas características agronômicas. O melhoramento de milho tem sido conduzido, principalmente, para a obtenção de maiores produções por planta. A eficiência das plantas, porém, tem recebido uma atenção secundāria em nosso meio. Sabe-se, no entanto, que o milho atual não é uma planta eficiente, estando ainda distante de um tipo ideal ou ideotipo. Tendências recentes tem mostrado a necessidade de se obter plantas não só mais produti vas como também mais eficientes na conversão de nutrientes em grãos.

0 conhecimento perfeito dos diferentes caracteres da planta e o seu relacionamento com a produção são de suma importância para um profundo conhecimento da planta em si e para uma melhor compreensão do processo produtivo. Conhecen do-se bem os diferentes caracteres que tem influência direta so bre a produção, pode-se realizar programas de melhoramento mais objetivos, tendo-se a vantagem de além de estar promovendo um melhoramento substancial na produção, estar ainda melhorando o tipo da planta, tornando-a mais eficiente, o que terä influência direta na diminuição dos custos de produção.

Como acontece com as demais culturas de importância econômica, o melhoramento do milho também se dirige para os aspectos considerados mais importantes pelos consumidores. Dessa forma, de acordo com as preferências dos consumido 
res e de acordo com as finalidades, ter-se-ä diversos objetivos a atingir com os trabalhos de melhoramento da cultura. Por exemplo, dá-se uma preferência generalizada para os milhos de sementes de coloração amarela, em detrimento dos milhos de sementes de coloração branca que são menos cultivados, a não ser para finalidades específicas. Assim, a grande maioria dos pro gramas de melhoramento está dirigida para a incrementação da produção de milhos amarelos, sendo dedicada pequena atenção ao me 1 horamento de milhos brancos.

No melhoramento de milho são utilizados métodos de melhoramento intra e interpopulacionais. Para que os métodos de seleção sejam bastante eficientes é necessārio que a população empregada apresente grande variabilidade genética. Para isso foram desenvolvidas populações que apresentam muito maior variabilidade genética que a encontrada nas varie dades existentes. Para tanto, reuniu-se diferentes variedades numa só população, a qual é chamada de "composto". Esses compostos apresentam grande variabilidade genética. Em compostos em cuja formação entram milhos brancos e amarelos, tem- se uma grande variabilidade em relação à coloração dos grãos. Tem-se grãos amarelos e brancos e ainda um grande nümero de co lorações intermediārias. A utilizä̧ão destes compostos representa um grande avanço no melhoramento do milho, uma vez que permite a utilização de níveis bem mais elevados de variabilidade e produtividade, levando à obtenção de maior ganho genéti co por geração. 
Nos ūitimos anos, muitos autores tem apresentado evidências e suspeitas de que os milhos brancos apresentam maior capacidade produtiva do que os milhos amarelos. Esta pos sibilidade abre novas e interessantes perspectivas para a exploração econômica do milho, com os milhos brancos passando a ocupar uma parcela maior do mercado.

Dessa forma, torna-se interessante uma avaliação comparativa da produtividade de milhos brancos e amarelos, juntamente com uma avaliação de outros caracteres de influência direta e indireta sobre a produção. A avaliação desta série de caracteres torna-se interessante do ponto de vista de se ter uma idéia mais precisa sobre quais caracteres possam estar tendo uma influência positiva ou negativa sobre a produção, contribuindo para a superioridade produtiva desta ou daque 1 a população.

0 conhecimento destes caracteres permitirā um maior conhecimento da planta em si, proporcionando meios para a realização de programas de melhoramento visando melhorar os caracteres nos quais esta ou aquela população (branca ou amarela) mostrou-se deficiente, contribuindo com isso também para um melhoramento na eficiência produtiva das populações e da cultura.

Para que uma avaliação desta natureza forneça resultados precisos é necessärio que os milhos brancos e amare los tenham a mesma base genética. A utilização de compostos 
.08 .

com segregação para sementes brancas e amarelas permite a sepa ração das populações desejadas e a realização dos testes neces särios com maior precisão e segurança.

Assim, de maneira geral, este trabalho objetiva, principalmente, determinar se a coloração das sementes apresen ta alguma influência sobre a capacidade produtiva das duas populações e quais os caracteres, dentre os analisados, que podem estar contribuindo para a superioridade ou inferioridade produtiva das populações. 


\section{REVISAO DE LITERATURA}

Em termos nutritivos, os milhos amarelos levam decidida vantagem, uma vez que apresentam maior conteūdo vitamínico do que os milhos brancos, sendo assim muito mais importantes para a alimentação humana e animal. A relação entre o valor vitamínico de certas linhagens e a coloração das sementes foi estudada por värios autores. STEENBOCK (1919), STEENBOCK e BOUTWELl (1920), HAUGE e TROST (1928), HAUGE (1930) e PAULSEN e LIO (1942) determinaram a existência de uma correlação positiva entre a coloração do endosperma e a quantidade de pró-vitamina A, bem como a falta dessa pró-vićamina nas sementes brancas.

o valor vitamínico das sementes coloridas depen de ainda da dosagem dos genes $Y$ no endosperma. ós trabalhos de HAUGE e TROST (1930), MANGELSDORF e FRAPS (1931) e JOHNSON e MILlER (1938) mostraram que as sementes de constituição gené tica do endosperma YYY são respectivamente mais ricas do que 
aquelas de constituição YYy e Yyy. Esses resultados são confirmados por GRANER (1950).

GRANER (1950) considera que o conhecimento da base genética que regula a presença dos pigmentos carotenóides na semente do milho é muito importante. Considera também de grande importância a obtenção de linhagens que reúnam aos caracteres de valor econômico uma maior quantidade de pigmentos, a fim de associar à fonte de proteína e hidrato de carbono uma melhor fonte de vitamina A.

Porém referências da literatura sobre o comportamento relativo de milhos brancos e amarelos levam à suposição de superioridade dos milhos brancos sobre os amarelos. Assim, por exemplo, sabe-se que no México os milhos brancos da raça Tuxpeño são bem mais produtivos do que os milhos amarelos da mesma raça. Na Colômbia, a variedade Eto Blanco é mais pro dutiva do que a Eto Amarillo, muito embora, ambas tenham a me ma origem. No sul dos Estados Unidos, onde milhos brancos e amarelos são cultivados, parece que os primeiros apresentam uma certa superioridade. Mesmo no Brasil, há informações da superioridade dos milhos brancos sobre os amarelos, como o Cristal e o Cateto, muito embora neste caso, se tratem de raças di ferentes.

A literatura existente sobre produção de milho em geral e sobre os caracteres considerados componentes é mui- 
to extensa, existindo uma quantidade enorme de dados. A p1anta de milho em si já foj exaustivamente examinada sob os mais diversos aspectos e desde cedo procurou-se associar a produção com os mais diferentes caracteres da planta. Procurou-se, inclusive, relacionar esses caracteres entre si, com a finalidade de detectar associações secundárias com relação à produção. Dessa forma, existe uma grande quantidade de informações sobre o assunto, muitas vezes contraditórias, o que serve como indicação de que certos caracteres e certas associações variam conforme o material utilizado e também conforme as diferentes técnicas experimentais utilizadas em sua determinação.

Devido à grande quantidade de caracteres existentes, procurou-se separā-1os em diferentes grupos, para permitir uma melhor anālise e melhor organização dos mesmos.

3.1. Relações entre a produção e caracteres morfológicos da planta

A 1iteratura sobre estudos relacionados com a herança da altura da planta e da espiga é bastante extensa. Po de-se dizer que a base genética desses caracteres já é definida, pelo menos no que diz respeito à herdabilidade e ao tipo predominante de ação gênica. A altura da planta e da espiga apresentam herdabilidade relativamente alta, segundo os trabalhos de ROBINSON et a1ii (1949) e QUEIROZ (1969). 
Inümeros trabalhos foram conduzidos visando determinar quantitativamente as correlações entre a produção e a altura da planta e/ou da espiga. Neste aspecto correlações po. sitivas e significativas foram detectadas por ROBINSON et alii (1951), GREEN (1955), MURTY e ROY (1957), JUGENHEIMER (1958), LINDSEY et alii (1962), GOODMAN (1965), CAMPOS (1966), ELROUBY e PENNY (1967), LONNQUIST e CASTRO (1967), TAVARES e ZINSLY (1971) e JOHNSON (1973). Porém, am outros casos não foram signi ficativas as correlações entre altura da planta e/ou da espiga com a produção, conforme resultados relatados por HALIAUER e WRIGHT (1967), QUEIROZ (1969), OBILANA e HALLAUER (1974) e por SHEHATA (1975). Apesar dos resultados não significativos encontrados em seus trabalhos, SHEHATA (1975) considera que plantas grandes com espigas altas e maturidade tardia tenden "a produzir mais grãos e que a ligação influencia parcialmente es ses resultados.

EWING (1910), WOLFE (1924), LINDSTROM (1935) par tindo de dados experimentais na geração $F_{2}$ de cruzamentos entre linhagens, HAYES e JOHNSON (1939) entre linhagens e seus respectivos "top-crosses", MURTY e ROY (1957) entre variedades, verificaram a existência de correlação positiva e signifi cativa entre produção e diâmetro do colmo. VILLANo (1966) ut 1 izando variedades e suas gerações $F_{1}$, constatou uma correlação positiva entre comprimento e largura da folha da espiga prin cipal e pròdução. 
Segundo GARNER e ALLARD (1920), o caráter nümero de folhas por planta é importante porque determina as proporções relativas entre as partes vegetativas e reprodutivas da planta. Além disso, esse caräter tem relação com a produção de grãos, com a densidade ótima de plantas por unidade de área cultivada para máxima produção e, também, com a capacida de competitiva da planta em relação a outras plantas da mesma população, outras variedades ou outras espécies.

Análises detalhadas sobre as influências exercidas pelo tipo de pendão sobre a produção e o comportamento da planta de milho em si vem sendo conduzidas pelos geneticistas com crescente interesse. As informações contidas na literatura sobre a influência da ausência ou presença do pendão so bre a produção são bastante contraditórias, o que é basicamen te decorrente das técnicas de despendoamento utilizadas nos di ferentes trabalhos. Dessa forma, temos que WATSON (1893), NEWMAN (1893), GARDNER (1894) e SMITH et alii (1895) mostraram que a produção de milho aumentou com o despendoamento. KIESSELBACH (1922) despendoou milho por oito anos para determinar seu efei to sobre a produção, notando aumento na produção. os pendões foram retirados logo no seu surgimento sem provocar injürias nas folhas. Por outro lado, HAYWARD (1891), INGERSOLL (1892) e MILls (1893) mostraram que ocorriam reduções na produção com o despendoamento. INGersoll (1892) obteve uma redução de 25-35\% em 1891 e $56,66 \%$ em 1892. Estes resultados negativos devem ser 
devidos a diferenças nos graus de mutilação das plantas pelos diferentes mätodos de despendoamento.

LEONARD e KIESSELBACH (1932) determinaram um a mento de $1,5 \%$ na produção com o despendoamento. Essa diferença, entretanto, não é significativa e os autores concluíram que a produção não é afetada com o despendoamento quando este é feito de tal modo que não mutile as folhas e que haja suficien te provisão de pólen.

DUNGAN e WOODWORTH (1939) determinaram um ganho pequeno com o despendoamento sem mutilações, porém com mutilação de $1,2,3$ e 4 folhas, a produção foi reduzida de acordo até um máximo de $29,2 \%$ quando 4 folhas foram removidas.

De maneira geral, os diversos autores relatam ganhos mínimos com o despendoamento, acompanhados de perdas pro gressivas quando no despendoamento são removidas folhas. Porëm, estudos mais detalhados e mais precisos forneceram resultados mais consistentes. GROCAN (1956) conduziu experimentos de de $\underline{s}$ pendoamento com hỉbridos em condições de seca, baixa fertilida de do solo e densidade de plantio acima do Etimo. Determinou aumentos na produção com o despendoamento, sendo que estes foram expressos por menos plantas estéreis e espigas maiores. A resposta ao despendoamento é atribuída à diminuição da competí ção por nutrientes entre o pendão e a espiga. Observaram também que em lotes despendoados o "embonecamento" das espigas ocorreu $1-3$ dias antes dos lotes não despendoados. 
DUNCAN et alii (1967) consideram que existe uma correlação 1 inear entre efeitos de sombreamento do pendão e ta xas de fotossíntese e produção de grãos e que o sombreamento pelos pendões pode reduzir a produção de grãos de $4-12 \%$ com densidades de plantio de 10.000 a 30.000 plantas/acre. Consideram ainda que, devido aos efeitos provocados pelos pendões sobre a produção, é interessante a seleção de variedades com pendões pequenos.

Esta consideração é muito importante sob vārios aspectos. Diminuiria de forma significativa o sombreamento exer cido pelos pendões, diminuindo a competição pela luz, trazendo conseqüente aumento na capacidade fotossintëtica, o que, de uma certa forma, implica em maiọ eficiência da planta. Por outro lado, está comprovada a existência de uma competição por nutrientes entre o pendão e a espiga, o que significa que o pen dão utiliza nutrientes que seriam muito importantes na produção de grãos. Assim, pode-se concluir que quanto maior o pendão, maior a taxa de nutrientes desviada para sua formação e manutenção, maior a influência negativa na produção de grãos.

Neste sentido, GERALDI (1977) encontrou resultạ dos muito interessantes. Estudando diversos caracteres do pen dão em três populações de milho encontrou correlação negativa e altamente significativa entre produção e número de ramificações e correlação negativa, porém, não significativa entre pro dução e peso do pendão. Estes resultados vem confirmar dife- 
rentes suposições jā feitas por diferentes melhoristas, de que quanto maior o pendão, maior o efeito negativo sobre a produção de grãos.

EWING (1910), WOLFE (1924) e JENKINS(1929) analisando observações dentro de linhagens, MURTY e ROY (1957) a partir de observações entre variedades, determinaram que o nümero de dias para o florescimento está negativamente correlacio nado com a produção. Entretanto, JENKINS (1929) em observações entre hỉbridos simples, entre linhagens e seus respectivos hỉbridos simples e HAYES e JOHNSON (1939) analisando linha gens e seus "top-crosses" encontraram uma correlação positiva e significativa entre tempo de florescimento e produção. JONES (1954) encontrou correlações positivas e altamente significati vas entre tempo de florescimento e produção e umidade na co1 heita e produção. Resultados obtidos por LINDSEY et alii(1962) e LONNQUIST et alii (1966) utilizando progênies biparentais de variedades vieram confirmar a existência desta correlação pos tiva e significativa. GOODMAN (1965) a partir de progênies b parentais obtidas de dois compostos, constatou uma correlação positiva e significativa entre tempo de florescimento e produção numa das populações estudadas em dois locais, sendo que a outra população não mostrou qualquer significância nos dois locais. Estes dados sugerem um possível efeito do tipo de material estudado na magnitude das correlações. Porém, resultados contrastantes foram obtidos por JUGENHEIMER (1958) entre linhagens, HOEN e ANDREW (1959) entre híbridos, CAMPOS (1966) 
dentro de variedades e híbridos e VILLANo (1966) entre varieda des e entre híbridos simples destas variedades, que não encontraram significância na correlação entre estas caracteristicas. O teor de umidade do grão na colheita mostrou uma correlação positiva e significativa com a produção entre híbridos nos trabalhos de HOEN e ANDREW (1959) e por CAMPOS (1966) den-tro de variedades e híbridos. GARDNER (1961) e LONNQUIST (1961) determinaram em seus estudos que a um aumento ra produção corresponde um aumento no ciclo da planta. Entretanto, PATERNIANI e ZINSLY (1965) relataram que um substancial aumento na pro dutivjdade não causou nenhum aumento no ciclo da planta.

As características acamamento e produção não mos traram correlação nos trabalhos de JUGENHEIMER (1958) entre 1i nhagens, CAMPos (1966) dentro de uma variedade, ELROUBY e PENNY (1967) em progênies biparentais de uma variedade. CAMPOS (1966) obteve correlação negativa e significativa entre acamamento e produção em uma variedade e híbridos.

3.2. Relações entre produção e caracteres da espiga e do grão

WILLIAMS e WELTON (1915) relatando os resultados de 10 anos de experimentação, afirmam que a produção não apresentou correlação significativa com caracteres da espiga. Em seus trabalhos foram comparadas as produçóes de plantas de 
espigas curtas versus longas e de cilíndricas versus cônicas. Entretanto, uma série de outros trabalhos mostram a existência de uma série de interessantes associações entre os diferen tes caracteres da espiga e do grão e a produção.

Assim, DAVENPORT (1907), HUTCHINSON e WOLFE (1918), WOLFE (1924) e RICHEY (1925) encontraram correlações positivas e significativas entre tamanho da espiga e produção. JENKINS (1929) constatou também a existência de correlação positiva dentro de linhagens e entre linhagens e seus respectivos hỉbridos simples. Igualmente, foi observada por LINDSTROM (1935) dentro do $\mathrm{F}_{2}$ de 1 inhagens, por HAYES e JOHNSON (I939) entre linhagens e seus "top-crosses" e por HALLAUER ee WRIGHT (1967) em progênies biparentais de uma variedade. SHEHATA (1975) encontrou considerāvel influência do tamanho da espiga sobre a produção em populações parentais, $F_{1}$ e $F_{2}$. Entretanto, CUNNINGHAM (1916) LOVE e WENTZ (1917), BRUNSON e WILLIER (1929), em suas observações dentro de variedades, afirmam que esta caracte rỉstica tem pouca relação com a produção, embora CUNNINGHAM (1916) afirme que os materiais não tem comportamento idêntico quanto a isto. BIGGAR (1919) encontrou correlação entre o tamanho da espiga e a produção, porém não consistentemente alta. Porēm, ROBINSON et alii (1951) utilizando progênies biparentais obtidas dentro do $\mathrm{F}_{2}$ de hỉbridos simples concluíram a partir de correlações genéticas e fenotípicas que este caráter não tem nenhuma relação com a produção. 
THIELE ( 1899 ) determinou que quanto maior o dia â metro da espiga, maior a porcentagem de sabugo. LOVE e WENTZ (1917) usando material selecionado a partir da variedade dente amarela Funk Ninety Days, afirmaram que características como proporção entre circunferência na ponta e circunferência na base e circunferência média do sabugo não mostraram correlação significativa suficientemente alta para ter valor no julgamento de espigas para semente. A circunferência média da espiga foi a unica característica que mostrou correlação significativa com a produção. GRANThAM (1917) dentro de variedade, encontrou correlação positiva entre circunferência do sabugo e produção. HUTCHINSON e WOLFE (1918) concluíram que circunferência mëdia da espiga, circunferência média do sabugo, uniformidade e fidelidade ao tipo, forma da espiga apresentam correlação significativa com a produção. BRUNSON e WILLIER (1929) dentro de variedade, encontraram correlação negativa entre diâme tro da espiga, circunferência da espiga e nümero de fileiras por espiga com a produção. Nos trabalhos de ROBINSON et alii (1951), o diâmetro da espiga não mostrou correlação fenotípica ou genotípica com a produção em progênies biparentais do $F_{2}$ de híbridos simples. Entretanto, WILlIAMs et alii (1965) utilizando progênies biparentais obtidas de uma variedade, constataram uma correlação genética e fenotípica relativamente a1ta entre essa característica e a produção. ShehAtA (1975) determinou a existência de correlação significativa e positiva com produção de gräos ao nível genotípico e fenotípico. 0 au- 
tor observou que o diâmetro da espiga apresentou considerável efeito direto sobre a produção em todas as populações estudadas. QUEIROZ (1969) considera que a anälise do grau de associação da produção com o diâmetro ou circunferência e com o comprimento da espiga é inadequada quando se trata de plantas prolíficas. Nestas, embora as espigas sejam reduzidas em rela ção às espigas de plantas não prolïficas, a produção por plant’a é superior.

LOVE (1912), GRANTHAM (1917), CAMPOS (1966), TAVARES e ZINSLY (1971) encontraram correlaçöes significativas e positivas entre peso da espiga e a produção dentro de varieda des. Esta correlação, foi também observada por RicheY (1925) e por MURTY e ROY (1957) entre variedades. LOVE e WENTZ(1917) determinaram uma correlação entre peso médio do sabugo e produção, porém não suficientemente alta para ter valor. Igualmen te, BIGGAR (1919) encontrou correlação entre peso da espiga e produção, porém não consistentemente alta.

JUGENHEIMER (1958) não encontrou correlação entre peso do grão e produção, resultado também encontrado por HALLAUER e WRIGHT (1967). Porém, BRUNSON e WILLIER (1929), HOEN e ANDREW (1959), WILLIAMS et alii (1965), CAMPOS-(1966), ELROUBY e PENNY (1967) e QUEIROZ (1969) constataram correlações positivas e significativas entre esses caracteres.

SCONCE (1911) trabalhando com as variedades Reid 
Yellow Dent e Johnson County White, verificou que as espigas contendo de 18 a 20 fileiras de gräos apresentam as maiores produções. LOVE e WENTZ (1917), HUTCHINSON e WOLFE (1918), BIGGAR (1919) e CAMPOS (1966) não encontraram correlação significati va entre número de fileiras da espiga e produção dentro de variedades. Entretanto, RICHEY (1925) obteve uma correlação negativa e significativa entre estas caracteristicas. KYLE e STONEBERG (1925) obtiveram resultado idêntico, quando plantas de menor numero de fileiras produziram mais dentro de variedades prolíficas e não prolíficas. HOEN e ANDREW (1959) a partir de observações entre híbridos e discordando dos demais autores, determinaram uma correlação positiva e significativa en tre nümero de fileiras e produção. Mostraram, porem, que a correlação entre o número de grãos por fileira da espiga e pro dução não mostrou significância consistente de um ano para ou tro. Igualmente, VILlano (1966) realizando observações em variedades e seus cruzamentos concluiu que o número de fileiras, nümero de grãos por fileira e o nümero de grãos por espiga estão correlacionados positivamente com a produção. Porém, QUEIRoz (1969) determinou que o nümero de fileiras apresenta corre 1 ação com a produção, sendo, entretanto, a correlação muito bai xa para permitir previsões seguras em programas de melhoramento. O autor determinou também associação. não consistente entre nümero de grãos por fileira e produção.

o nümero de espigas por planta mostrou-se corre lacionado com a produção dentro de linhagens, dentro de híbri- 
dos simples e entre linhagens e suas respectivas gerações F , segundo JENKINS (1929) e BRUNSON e WILLIER (1929) dentro de vą riedade. Esta correlação, tambēm, foi evidenciada em progênies biparentais de uma população $F_{2}$ de híbridos simples nos trabalhos de ROBINSON et alii (1951), por HOEN e ANDREN (1959) entre híbridos, por GoODMAN (1965) em progênies biparentais de compostos, por CAMPOS (1966) dentro de variedades e híbridos, por LONNQUST et alii. (1966) em progênies biparentais de uma variedade, por VILLANo (1966) num estudo envolvendo variedades e seus cruzamentos e por QUEIROz (1969). Utilizando linha gens, seus híbridos simples, geração $F_{2}$ e vārios retrocruzamen tos, LIABLE e DIRKS (1968) concluíram que a seleção para produ tividade baseada num índice composto de número de espigas e pro dução, foi mais eficiente do que a seleção baseada unicamente na produção. Estes resultados estão de acordo com as evidências experimentais obtidas por BAUMAN (1960), onde a segunda espiga apresentou uma contribuição significativa para a produção. O autor ainda indica que um aumento de peso total de espigas é mais facilmente conseguido com o aumento da prolificidade (nümero de espigas). Dessa maneira,segundo CAMPos (1966), boas condições de desenvolvimento são melhor aproveitadas por plantas que produzem duas espigas dro que por plantas que produ zem apenas uma. LONNQUIST (1967) relatou que seleção para pro lificidade foi mais eficiente no aumento da produtividade que a seleção para produção per se. SHEHATA (1975) relatou corre1 ação positiva entre produção e prolificidade ao nível fenotí- 
pico e genotípico. Determinou também considerāveis efeitos di retos sobre a produção em todas as populações estudadas.

o rendimento de grãos na espiga apresentou correlação com a produção dentro de linhagens, entre linhagens e seus híbridos simples, segundo relatos de JENKINS (1929). Porēm, LOVE e WENTZ (1917), HUTCHINSON e WOLFE (1918), BIGGAR (1919) a partir de observações dentro de variedades, HAYES e JOHNSON (1939) entre 1 inhagens e seus respectivos "top-crosses", MURTY e ROY (1957) entre variedades, CAMPOS (1966) dentro de variedades e híbridos, concluíram que esta característica não apresentou associação consistente com a produção. CAMPos (1966) encontrou resultados contraditórios entre os materiais estudados, indicando grande influência do tipo de germoplasma estuda do. Quando o rendimento é baixo devido grande variabilidade no material, pode-se esperar que haja aumento nesse carāter sem pre que houver aumento na produção. Porém, quando o nível de rendimento jà é alto, haverá diminuição da correlação e menores aumentos, entrando aí a influência decisiva do tipo de materia 1. Ainda, CAMPos (1966) observou uma correlação positiva e significativa entre nümero médio de grãos por planta e produ ção. SCONCE (1911) verificou existir correlação positiva entre boa conformação do grão e produção. HUTCHINSON e WOLFE (1918) determinaram correlação significativa entre uniformidade e forma dos grãos e produção. Determinaram também que a correlação entre comprimento médio do grão, características da base da espiga, espaço entre grãos e entre fileiras e a prodü 
ção é pequena. BRUNSON e WILliER (1929) dentro de variedades, determinaram que comprimento, largura e espessura do grão não estão correlacionados com a produção.

3.3. Relações entre caracteres morfológicos da planta e da espiga

Todos os estudos sobre correlações em milho tem mostrado, invariavelmente, uma alta correlação positiva entre altura da planta e altura da espiga. ROBINSON et alii (1951) em progênies biparentais de uma população $F_{2}$ de hỉbridos simples, JUGENHEIMER (1958) entre linhagens, HOEN e ANDREW (1959) entre hîbridos, GOODMAN (1965) em progênies biparentais de com postos em dois locais, LINDSEY et a1ii (1962), ELROUBY e PENNY (1967), HALLAUER e WRIGHT (1967) em progênies biparentais de variedades e VILLANO (1966) entre variedades e seus cruzamentos, encontraram alta correlação positiva entre altura da plan ta e altura da espiga. QUEIRoz (1969) considera que em virtude dessa forte correlação entre a1tura da planta e altura da espiga, é provāvel que o grau de associação de cada uma destas caracteristicas com as demais seja praticamente o mesmo.

MURTY e ROY (1957) determinaram correlação pos tiva entre peso do grão e tamanho da espiga entre variedades, entretanto WILLIAMS et a1ii. (1965), HALLAUER e WRIGHT utilizando progênies biparentais de variedades não constata- 
ram correlação consistente entre esses caracteres. Nos traba1hos de JUGENHEIMER (1958), o peso do grão apresentou correlação com altura da planta e altura da espiga entre linhagens e somente com a altura da espiga entre hỉbridos, conforme relato de HOEN e ANDREW (1959). As observações de SHEHATA (1975) indicaram que plantas altas são positivamente correlacionadas com espigas longas e diâmetros grandes. 0 autor relatou também a existência de correlação entre prolificidade, tamanho e diâme tro da espiga, correlações estas positivas, porēm pequenas.

o nümero de fileiras por espiga foi negativamente correlacionado com o peso do grão e tamanho da espiga,segun do observações de WILLIAMS et a1ii (1965) e HALLAUER e WRIGHT (1967) em progênies biparentais de variedades. Apresentou, con tudo, correlação genética positiva com o diâmetro da espiga. ALEXANDER (1952) considera que na maioria dos hỉbridos e das 1 inhagens por ele estudados, espigas com pequeno número de fileiras foram formadas nos nós mais baixos e espigas com grande nümero de fileiras foram formadas a cada nó sucessivamente mais alto (quanto mais alto o nó, maior o número de fileiras da espiga). Segundo BERGER (1968), espigas individuais podem ter de 4-30 ou mais fileiras de grãos. 0 nümero de fileiras de uma espiga é parcialmente determinado hereditariamente, mas, es pecialmente em variedades com grande número de fileiras,o núme ro pode ser afetado pelo ambiente.

o nūmero de espigas por planta não apresentou correlação significativa com o peso da espiga, peso total de 
grãos por planta, nümero médio de grãos por planta e peso do grão, dentro de variedades e hỉbridos, segundo observações de CAMPos (1966). Entre 1 inhagens, JUGENHEIMER (1958) não encon trou correlação entre o número de espigas por planta e altura da planta e altura da espiga e, ROBINSON et alii (1951) em pro gênies biparentais de um $\mathrm{F}_{2}$ de híbridos simples não encontrou correlação deste caráter com o tamanho da espiga. HOEN e ANDREW (1959) realizando observações entre hỉbridos, mostraram que o nümero de espigas por planta foi negativa e significativamente correlacionado com a altura da espiga num ano, não o sendo com altura da planta neste ano, nem com altura da planta e da espi ga no ano seguinte. Goodman (1965) utilizando progênies biparentais de compostos, observou que a correlação entre nümero de espigas por planta e altura da planta e da espiga não apresentou significância consistente de uma localidade para outra. VILLANO (1966) observou que entre variedades e entre seus híbridos simples, o nümero de espigas apresentou correlação posi tiva e significativa com a altura da planta. Verificou, ainda, que esta característica foi correlacionada com o número de fileiras da espiga e com o número de grãos por fileira.

De VRIES (1901) determinou que o tamanho do grão diminuía com o aumento do nümero de fileiras. GRANThAM (1917) fazendo diversas observações na variedade Johnson County White determinou diversas associações entre caracteres da espiga. A sim, determinou que, em geral, sabugos com circunferência gran de tem um número maior de fileiras de grãos do que espigas com 
pequena circunferência. Quanto maior o numero de fileiras em uma espiga, a circunferência permanecendo constante, menos 1 ar gos serão os grãos. Grãos com largura pequena tem tendência de serem mais leves do que grãos mais largos. Por outro 1 ado, uma espiga com pequeno nümero de fileiras, provavelmente terä grãos mais largos. O autor determinou que a correlação entre circunferência do sabugo e peso do grão è muito pequena para ter valor. Foi encontrada uma tendência moderada de que sabugos com grande diâmetro (circunferência) tem grãos com inserção mais rasa. O autor determinou também uma correlação levemente negativa entre circunferência do sabugo e espessura do grão, o que indica que sabugos finos tem maior tendência de apresentarem grãos mais espessos. Não foi encontrada correlação entre peso do sabugo e peso do grão, havendo indicação de que sabugos pesados produzem grãos mais leves. Há indicação também de que não existe correlação muito alta entre circunferência do sabugo e peso do sabugo, o que permite concluir que sabugos largos e grandes devem ter densidade menor, sendo por esta razão não proporcionalmente mais pesados que sabugos menores. Foi en contrada uma pequena correlação negativa entre peso do sabugo e espessura do grão, o que é uma indicação de que sabugos pesa dos apresentam maior tendência de produzir grãos finos do que grossos. O autor determinou, ainda, uma correlação moderadamente negativa entre densidade do sabugo e peso do grão,o que indica que sabugos com maior densidade apresentam grãos mais leves. Existe uma tendência muito pequena de sabugos com den- 
sidade pequena apresentarem grãos espessos.

BRUNSON e WILIIER (1929) analisando a variedade Pride of Saline fizerami värias observações interessantes. Determinaram que grande nümero de fileiras por espiga está associado com espigas grossas, com pequeno espaço entre as fileiras e com grãos desuniformes e leves, com pequeno espaço entre estes grãos, sendo estes ainda compridos e de grande espessura. Afirmaram que espigas com grãos de indentação desuniforme são, em geral, pequenas e grossas com muitas fileiras de grãos, sendo estes longos e finos, existindo porëm pouca relação entre peso do grão ou largura do grão e indentação. Espaços gran des entre fileiras de grãos (grãos arredondados) foram encontrados com maior frequência em espigas pequenas e finas com pou cas fileiras de grãos pesados e uniformes, com tendência a serem largos e pequenos. Grãos pesados mostraram-se associados a espigas compridas e grossas com poucas fileiras de grãos com pridos, largos e espessos. Grãos compridos foram encontrados com maior freqüência em espigas pequenas e grossas com muitas fileiras de grãos de indentação desuniforme, pesados, finos e com espaço muito pequeno entre as fileiras de grãos. Grãos lar gos foram encontrados com maior frequência sobre espigas compridas com poucas fileiras de grãos espessos, pesados e com grandes espaços entre as fileiras de grãos. Foi determinada alta correlação entre largura do grão com peso do grão e filei ras de grãos. Determinaram, ainda, que grãos espessos são encontrados com maior freqüência em espigas compridas e grossas 
com muitas fileiras de grãos uniformes, pesados, pequenos e 1 argos.

LOOMIS e WILLIAMS (1963) mostraram que, à medida que aumenta o número e o tamanho das folhas durante o desenvolvimento do cereal (isto é, aumenta o indice foliar), tam bém aumenta a absorção de 1 uz e a produção relativa de matéria seca. Nozzolini (1963) relatou correlações positivas e altamente significativas entre nūmero de folhas de uma planta de milho e duração do período vegetativo em milho cultivado em vâa rios locais da Itälia. Afirmou também que número de folhas por planta é um caräter praticamente constante, pouco influenciado por fatores ambientais. Confirmando resultados de NozzoliNI (1963), CHASE e NANDA (1967) estudando 21 hỉbridos dupios de milho ( 18 dentados e 3 semi-dentados), em três épocas de plantio, revelaram correlações positivas altamente significati vas entre o nümero total de folhas por hỉbrido e o nümero de dias para florescimento.

DUNCAN e HESKETH (1968) demonstraram que número de folhas é um índice do estāgio fisiológico de florescimento. Indução prematura do florescimento resulta em menor número de folhas, menor número de nós e, consequentemente, em plantas menores. Os autores encontraram também que o nümero de folhas mostrou-se altamente correlacionado com precocidade. NEAL (1968) observou a existência de correlação entre número de folhas e maturidade, ou seja, a um menor nümero de folhas se associa 
uma maior precocidade. HESKETH et alii (1969) observaram, em 18 hỉbridos simples e 2 raças de milho, que a temperatura, o fo toperiodismo e o genótipo, tem forte efeito sobre a modificação do número de folhas da planta. Os resultados mostraram também que o número de folhas é correlacionado com o número de dias para florescimento, com ärea foliar, peso seco e altura da planta.

3.4. Relações entre caracteres do sistema radicular e os caracteres gerais da planta

De acordo com Collins (1914), värios termos são comumente usados referindo-se à primeira raiz ou raízes produzidas por sementes de plantas pertencentes à família gramỉnea. Ordinariamente quando só uma raiz é produzida pelo grão,ela é denominada como radícula. Quando mais do que uma raiz está pre sente, elas são frequentemente chamadas como raízes primárias ou temporárias ou seminais. ARAUJo (1975) considera como raízes nodais aquelas que se originam abaixo da semente. As raízes que se originam da base do cotilédone um tanto mais atrasa das que a radícula, são denominadas de raízes seminais secundá rias.

SMITH e WALWORTH (1926) mostraram que cada plan ta individual de milho possui diferentes números de raízes seminais secundārias produzidas por plântulas. Em seus estudos encontraram uma correlação positiva entre número de raízes se- 
minais e a produção. Encontraram também evidências de que a1ta produção de raízes está relacionada com vigor dos primeiros estágios de desenvolvimento. Com base nos resultados obtidos, os autores sugerem que a observação do número de raízes seminais juntamente com a realização do teste padrão de germinação serve como indicação adicional para a seleção de espigas com a finalidade de aumento da produtividade.

COLLINS (1927) encontrou evidências de que alta produção está correlacionada com pequeno nümero de raízes. MAN GELSDORF e GOODSELL (1929) estudando a variedade dentada de grãos brancos Surcropper fizeram uma série de observações inte ressantes. Determinaram que o nümero de raízes seminais varia significativamente com a posição da semente na espiga,variando tambēm com diferenças na temperatura e na umidade durante a ger minação. Cada espiga tem aproximadamente o mesmo nümero de raỉzes seminais, em mẻdia, sob diferentes condições. Observaram que o número de raízes seminais provou não ter associação com tamanho, diâmetro e forma da espiga, nūmero de fileiras de grãos e comprimento, largura, grau de indentação, aparência ou densidade específica dos grãos. Não encontraram também relação entre raízes seminais e produção. Porém, nümero de raízes seminais mostrou-se positiva e significativamente correlacionado com o vigor de plântulas quando estas foram germinadas em condições especiais e depois transplantadas para o solo, en. tretanto, o caráter mostrou-se negativa e significativamente correlacionado com o vigor de plântulas, quando as sementes 
foram plantadas diretamente no solo. Observaram que nümero de raízes seminais não tem relação com época de florescimento, altura da planta e altura da espiga, acamamento e porcentagem de plantas infectadas com carvão. Foi observada uma pequena correlação entre o nümero de raízes seminais e o número de nós nas progênies.

Existem evidências de relacionamento entre o pe so de raízes seminais e o vigor do desenvolvimento.

WILSON (1930) verificou que plantas que desenvolveram raízes suportes e possuem os três primeiros internōs pequenos acima do so10, apresentam bom índice de resistência ao acamamento.

Para medição do volume de raiz, MUSICK et a1ii (1965), ANDREW (1966) e NASS e ZUBER (1971) utilizaram as dife renças volumëtricas dos sistemas radiculares do milho que podem ser detectadas pelo deslocamento de água no aparelho de me dição para determinar o volume da raiz, o qual tem sido um indicador útil de bom ou pobre sistema radicular na maturidade.

NASS e ZUBER (1971) constataram que volume da raiz, pesototal da raiz e peso das raízes nodais apresentaram correlações positivas e altamente significativas com o peso do bloco de raízes e a resistência de arrancamento de plantas adultas em cultura de campo.

ARAUJO (1975) estudando a variabilidade do sistema radicular em diferentes cultivares de milho, observou que volume de raiz, peso total da raiz, peso total da planta, peso 
das raîzes nodais, número total de raízes e número de raízes nodais quando medidos no estägio inicial de desenvolvimento são indicadores úteis de um bom ou pobre sistema radicular na maturida de por serem altamente correlacionados entre si. Determinou que cultivares de milho que possuem sistemas radiculares mais vastos e com maior rapidez de crescimento no seu estägio inicial de desenvolvimento, poderão possuir um sistema radicular mais forte e compacto na maturidade. Observou, ainda, que o volume da raiz demonstrou ser o melhor entre todos os caracteres para estimação de um bom sistema radicular, sendo também de fäcil manuseio.

ALLEONI (1976) estudando a variabilidade do sis tema radicular em um composto de milho, determinou que peso to tal da planta, peso total de raízes, peso de raízes seminais, peso de raízes nodais, nümero total de raízes, nümero de ra zes seminais, número de raízes nodais e porcentagem de raízes seminais são quase todos positivamente correlacionados, com exceção de porcentagem de raízes seminais que apresenta correlação negativa com os demais caracteres. Não foi possível detectar correlação genética significativa entre os caracteres de plantas jovens e acamamento.

3.5. Vigor de sementes: conceitos e relações com o desenvol vimentio das plantas

o vigor pode ser considerado sob dois aspectos: 
genético e fisiológico. O vigor genético pode ser observado na heterose ou nas diferenças genéticas entre duas linhagens. o fisiológico se refere à diferença de vigor entre dois lotes de sementes da mesma espécie, variedade ou híbrido. E importante ressaltar que o vigor fisiológico tem suas bases assenta das no vigor genético, sendo que nem sempre é fácil a identifi cação dos fatores que determinam o vigor fisiológico,principal mente no que diz respeito às diferenças de vigor entre popula ções geneticamente diferentes.

Muitos autores procuraram definir vigor de sementes, porém nenhum conceito $\vec{e}$ universalmente aceito. DELOUCHE e CALDWELl (1960) propõe que o vigor é a soma de todos os atributos da semente que favorecem um rápido e uniforme estabeleci mento das plantas no campo. Já WOOdSTOCK (1965) definiu vigor da seguinte maneira: "vigor é um estado de boa saūde e natural robustez das sementes, que permite que a germinação se processe rápida e completamente sob uma larga faixa de condições ambientais". Talvez a melhor definição seja a proposta por PERRY (1972): "vigor é uma característica fisiológica determinada pe lo genótipo e modificada pelo ambiente, que governa a capacida de de uma semente originar rapidamente uma plântula no solo e tolerar significativas variações do ambiente; a influência do vigor da semente pode persistir toda a vida da planta e afetar. a produção". Interessante, ainda, $\vec{e}$ a definição proposta por BURRIS (1975): "vigor de plântulas é a soma de todos os atributos da semente e da plântula que permitam ou promovam uma 
germinação rāpida $\in$ uniforme sob uma larga faixa de condições ambientais, seguida de emergência e cesenvolvimento rápiòos e uniformes das plântulas, culminando na manutenção de uma alta taxa de crescimento durante todo o período vegetativo". Confor me pode ser observado, existem muitas concepções de vigor e existe uma grande dificuldade de concordância entre os diversos autores .

Além da dificuldade de conceituação, existe tam bém uma grande dificuldade em definir quais são os atributos da planta que melhor servem para quantificar o vigor da mesma. Existe uma grande dificuldade de padronização de testes de vi-gor, sendo que para cada cultura existe a necessidade de estu dos preliminares para determinação dos testes que melhor se adaptem às exigências da cultura. Entretanto, o vigor se manifesta através de todos os estägios de desenvolvimento, em maior ou menor grau, sendo sua manifestação mais marcante nos primeiros estágios de desenvolvimento das plantas.

GRANTHAM (1917) considera que o "stand" de plan tas no campo pode ser perfeito e mesmo assim apresentar baixa produção. As plantas fracas podem ser resultado de condições ambientaịs, entretanto, essa menor capacidade de produção pode ser de origem genética, sendo a falta de vigor de parte do 1ote de sementes um dos fatores responsáveis.

GRABE (1966) considera incompletas as definições vigor que não incluam os efeitos do vigor sobre a produção e a 
capacidade de armazenamento. Considera maior ou menor vigor de sementes como, em parte, uma consequência de deterioração das sementes durante o armazenamento. Sem dúvida, maior ou me nor deterioração de sementes é um fator controlado geneticamente, ou seja, sementes mais vigorosas sofrem menos deteriora ção durante períodos longos de armazenamento do que sementes menos vigorosas. CLARK (1963) relata considerável perda de produção em plantios formados por sementes armazenadas precariamente, apresentando estas baixa germinação. Conclui-se das informações de CLARK (1963) que houve acentuada deterioração das sementes com perda de vigor, o que se refletiu na perda de poder germinativo das sementes e na baixa produção final. GRABE (1966) conclui, ainda, que o vigor de sementes é um reflexo da deterioração. Isto porque um grau moderado de deterioração cau sa redução na produção, enquanto que deterioração severa causa também diminuição do "stand". O grau de deterioração de se mentes também é uma indicação do tempo que as sementes podem permanecer em armazenamento. O autor ainda sugere a realização de testes de qualidade para avaliar o potencial de lotes de sementes quanto à capacidade produtiva, poder germinativo e capacidade de armazenamento.

PAULI (1967) considera o vigor, principalmente, pela capacidade de emergência rápida, uniforme e completa, de modo a proporcionar "stands" completos. 0 autor realizou estu dos sobre a utilização de hormônios para aumentar o poder germinativo de sementes, de modo que sementes de baixo vigor te- 
nham mais condições de enfrentar situações adversas. Entretan to, os primeiros resultados não permitem conclusões definitivas, havendo necessidade de novos estudos.

POLLOCK e ROOS (1972) fizeram compleaa revisão sobre o assunto e apontam que as principais formas de expressão de vigor são: crescimento da planta e produção, poder germinativo, comportamento uniforme, ausência de anormalidades mor fológicas. Os principais componentes do poder germinativo são velocidade de germinação, a qual é considerada um aspecto importantissimo do vigor, sendo que uma das formas de avaliā-1a é a utilização da primeira contagem do teste padrão de germjnação. o outro componente do poder germinativo é a taxa de crescimento. As principais anormalidades morfológicas que indicam pouco vigor ou o afetam são: perda de material de reserva na semente, danos em tecidos meristemäticos, danos vasculares, embriões anormais, etc... Os autores consideram ainda que as melhores formas de avaliar o vigor de sementes è submetê-las a condições de "stress", como altas temperaturas, alta umidade no solo, baixo teor de oxigênio, "stress" osmótico, etc... Para estas avaliações foram idealizados os mais diferentes testes como o teste do tetrazólio, teste de velocidade de emergência, teste de envelhecimento rápido, entre outros.

BURRIS (1975) analisando linhagens e híbridos simples entre elas, considera que qualquer fator que afete a semente durante seu, desenvolvimento, maturação e armazenamento, 
pode afetar também o vigor. Variabilidade genética e heterose exercem papel importante no grau de vigor de sementes, ressaltando-se a importância de efeitos maternos sobre o vigor. o a u tor considera que o vigor pode ter efeitos significativos sobre o comportamento das plantas no campo. 0 vigor $\vec{e}$ apenas um dos muitos fatores que afetam a formação de "stands" comple tos, não sendo muito correlacionado com emergência das plântu1as. Foi determinada uma associação consistente entre vigor de plântulas no laboratório e crescimento vegetativo inicial. Determinou que para muitos genótipos reduções no vigor conduzem a reduções na produção, mesmo que "stands" ótimos sejam con seguidos.

De certa forma, os estudos relacionados com o vigor de sementes ainda se encontram nos estágios iniciais devido, principalmente, à dificuldade de especificar e quantificar seus principais efeitos e também devido à dificuldade de elaboração de testes precisos e simples, que permitam uma me1hor avaliação desta característica. Entretanto, devido ao crescente interesse manifestado nos $\bar{u} 1$ timos anos pelos diversos pesquisadores por esta importante característica, deve-se esperar interessantes e importantes descobertas em futuro próximo, que permitirão uma seleção e produção de sementes cada vez melhores, capazes de produzir plantas cada vez mais superiores, o que terá como primeira e mais importante conseqüência, a obtenção de excelentes produções. 


\section{MATERIAL E METODOS}

4.1. Ensaios de produção e determinações relacionadas

$$
\text { 4.1.1. Material }
$$

0 material consiste essencialmente de um compos to, de uma variedade comercial e de dois híbridos comerciais.

$$
\text { o composto de milho utilizado é o Dentado Com- }
$$
posto SRR ơ Prolífico, o qual é constituído das seguintes popu 1 ações :

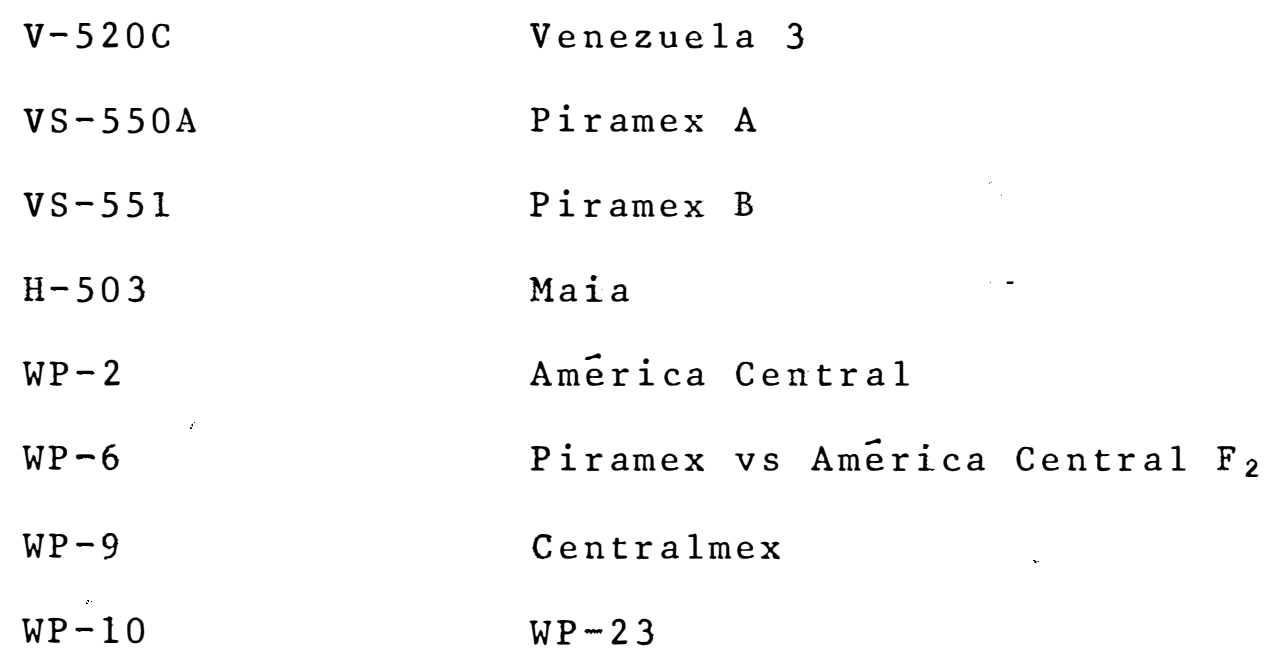


Capitein

Carmen
WP-25 La Posta

$\operatorname{Mix} 1$

Na formação deste composto não se procedeu qua 1 quer seleção quanto à coloração dos grãos, tendo sido utilizados milhos brancos e amarelos, pois a finalidade era a produção de populações de ampla base genética e de boa produtividạ de. Nestas condições, o composto apresenta segregação para se mentes brancas e amarelas, tendo sido sintetizado no Instituto de Genética.

Como variedade comercial foi utilizada a variedade Centralmex, com sementes de coloração amarela e sintetiza da no Instituto de Genética. $\bar{E}$ uma variedade sintetizada a partir do cruzamento entre as variedades da América Central e Piramex (PATERNIANI, 1968), tendo sido formada após vários ciclos de seleção recorrente, entre e dentro de famílias de meios-irmãos.

Como hỉbridos comerciais foram utilizados

o HDmd-7974 e o Ag-152. O híbrido HDmd-7974 é um híbrido duplo comercial, com sementes de aparência semi-dentada e coloração amarela, sintetizado pelo Instituto Agronômico de Campinas. 0 híbrido Ag-152, igualmente, è um híbrido duplo comercial, com sementes de aparência semi-dentada e coloração amarela, com en dosperma mole, produzido pela Sementes Agroceres S.A. 
4.1.2. Descrição dos Tratamentos

O Dentado Composto SRR ơ Prolífico apresenta se gregação para sementes brancas e amarelas, tendo-se assim sementes brancas, sementes amarelas e uma série de coloraçóes in termediárias entre o branco e o amarelo. No caso das sementes amarelas tem-se ainda uma variação na coloração do topo das mesmas. Há sementes com o topo branco, que é uma característí ca controlada pelo gen dominante Wc (White Cap). Hä também sementes com o topo bem amarelo e várias colorações intermediá rias entre o branco e o amarelo. Nos programas de melhoramento, em geral, dá-se mais importância às sementes como topo a marelo, uma vez que as sementes com o topo branco tem pouca aceitação comercial.

Para constituição de parte dos tratamentos utiIizados neste trabalho, tomou-se o Dentado Composto SRR ơ Prolífico e separou-se três populações, de modo que os tratamentos ficaram constituídos da seguinte maneira:

Tratamento nọ 1: Sementes de coloração branca, originárias do Dentado Composto ơ Prolífico, com constituição genética do endosperma yyy.

Tratamento nọ 2: Sementes de coloração amarela, com topo amarelo, originārias do Dentado Composto SRR ơ Prolífico, com constituição genética do endosperma YYY. 
Tratamento nọ 3: Sementes de colorações interme diärias entre o branco e o amarelo, com topos igualmente de colorações intermediárias, originärias do Dentado Composto SRR ơ Prolífico, com constituição genētica do endosperma YYy ou 'Yy.

Tratamento nọ 4: Sementes da variedade Central mex.

Tratamento nọ 5: Sementes do híbrido Ag-152.

Tratamento nọ 6: Sementes do híbrido HDmd-7974.

\subsubsection{Metodologia}

Os ensaios de produção foram conduzidos

por dois anos $(1975 / 76$ e $1976 / 77)$, tendo sido instalados no Bair ro da Āgua Santa, no Município de Piracicaba, sendo que as diferentes determinações relacionadas aos ensaios de produção fo ram igualmente realizadas por dois anos. A repetição dos testes em dois anos visa observar o comportamento da produção e de diversos caracteres relacionados em um período maior de tem po, de modo a eliminar o efeito mascarador dos efeitos ambientais, obtendo-se, assim, estimativas com maior grau de precí são, o que permitirá uma anāilse mais segura dos dados.

Os ensaios de produção tiveram sua instalação efetivada sempre durante o mês de outubro, tendo sido utiliza- 
do o delineamento experimental de Blocos ao Acaso, com lo repe e tições. Utilizou-se o espaçamento de 1 metro entre linhas por 0,40 metros entre covas, tendo sido semeadas 3 sementes por co va (75 sementes por parcela), restando após o desbaste, duas plantas por cova. Dessa forma, cada parcela completa ficou constituída por 25 covas, com 50 plantas e ärea de $10 \mathrm{~m}^{2}$.

Uma vez instalados os ensaios, foram realizadas várias determinações, tendo sido determinada primeiramente a é poca de florescimento. Por ocasião da época de emergência do pendão foram feitas observações regulares no campo, para não perder o início da emissão de pólem. Uma vez iniciada a emissão de pólem foram realizadas observações diārias, sendo consi deradas como florescidas as parcelas com $50 \%$ das plantas com pendões emitindo pólem. Os dados de época de florescimento só existem para o segundo plantio (1976/77), uma vez que ía1 has na metodologia de avaliação do florescimento, não permitiram a utilização dos dados coletados no primeiro plantio $(1975 / 76)$.

Por ocasião da colheita foram feitas as seguintes determinações:

- Sobrevivência final (stand)

- Ac amamento

- Altura da planta

- Altura da espiga 
- Nümero de folhas por planta

- Nümero de espigas por planta

- Tipo de pendão

Estas determinações foram realizadas nos dois a nos de plantio. Para obtenção do índice de acamamento föram consideradas como acamadas as plantas que sofreram quebramento do colmo abaixo da espiga e as plantas que sofreram acamamento radicular./A sobrevivência final foi determinada juntamente com o acamamento. As outras características foram determinadas em 10 plantas competitivas em cada parcela tomadas ao aca so, sempre que possível, tendo-se no final 600 observações por caräter por ano.

o carāter altura da planta, foi medido do solo até a inserção da ültima folha, em metros. A altura da espiga foi medida do solo até a inserção da espiga principal (espiga superior).

Para determinações do tipo de pendão, foram coletados 10 pendões por parcela, sempre de plantas competitivas, quando possível, e acondicionadas em saquinhos de papel previamente numerados (Por exemplo: 1.5.3, o que significa ter ceira flecha da quinta parcela da primeira repetição; 2.1.9, o que significa nona flecha da primeira parcela da segunda repetição, etc.), após o que foram levadas para o laboratório. Foram então contadas as ramificações existentes em cada pendão 
sendo feita a classificação de acordo com o seguinte sistema de notas:

$$
\begin{aligned}
& 0-5 \text { ramificações }=1 \\
& 6-10 \text { ramificações }=2 \\
& 11-15 \text { ramificações }=3 \\
& 16-20 \text { ramificações }=4 \\
& 21-25 \text { ramificações }=5
\end{aligned}
$$

$$
\begin{aligned}
& 26-30 \text { ramificações }=6 \\
& 31-35 \text { ramificações }=7 \\
& 36-40 \text { ramificações }=8 \\
& 41-45 \text { ramificações }=9 \\
& 46-50 \text { ramificações }=10
\end{aligned}
$$

Adotou-se o sistema de notas para classificar os pendões com a finalidade de simplificar e uniformizar as anotações. Ocorre muitas vezes que o pendão escolhido no campo perdeu algumas ramificaçoes durante o transporte do campo para o laboratório, ficando assim muito dificil precisar quantas ramificações o pendão realmente possui. Usando-se o siste ma de notas, tornou-se possível enquadrar o pendão em algum dos intervalos, sem perda de precisão, uma vez que foram esco 1hidos intervalos adequadamente amplos, para que pudessem ser compensadas as eventuais perdas de ramificações. Convém ressaltar que pendões que apresentassem falhas elevadas não foram coletados, devido ao problema de perda de precisão. Assim, a1ém de facilitar o trabalho de classificação dos pendões, o sistema de notas ainda apresenta a -vantagem de poder ser utili zado sem problemas nas anāises estatísticas.

Por ocasião da colheita, foram colhidas todas as espigas de cada parcela, sendo as espigas, jā despalhadas, 
acondicionadas em sacos de algodão, tendo-se ao final da co1heita 60 sacos, cada saco correspondendo a uma parcela. Para facilitar a identificação das parcelas, foi colocada uma etiqueta numerada dentro de cada saco.

Uma vez no laboratório, antes de ser iniciada a debulha das espigas e a pesagem dos grãos, foram separadas, aleatoriamente, 10 espigas de cada parcela, para realização das seguintes determinações:

- Número de fileiras por espiga

- Número de grãos por espiga

- Tamanho da espiga

- Diâmetro da espiga

- Peso da espiga

- Peso do sabugo

- Peso de 100 grãos

- Comprimento do grão

- Largura do grão

- Espessura do grão

Para determinação do caráter nümero de grãos por fileira, foi escolhida uma fileira representativa da espiga e feita a contagem de grãos. 0 caráter peso de 100 grãos foi determinado a partir de uma amostra de 100 grãos tomada aleatoriamente do total debulhado das 10 espigas de cada parce 1a. Para determinação das características comprimento, 1argu- 
ra e espessura do grão foram tomados, aleatoriamente, 5 grãos de cada espiga, tomando-se o cuidado de coletar os grãos da $\bar{a}-$ rea central da espiga, que é a área maís representativa da espiga em termos de caracteristicas dos grãos. Dessa forma, fo ram realizadas determinações em 50 grãos por parcela.

As espigas restantes foram debulhadas, sendo anotado o peso de grãos de cada parcela. No primeiro ano as espigas foram debulhadas manualmente (em debulhadeira manual) e feita a pesagem direta dos grãos. No segundo ano, foi tomado inicialmente o peso das espigas, apös o que foram debulhädas em debulhadeira elétrica, sendo anotado o peso dos sabugos. O peso dos grãos foi então determinado pela diferença en tre o peso das espigas e o peso dos sabugos.

os dados de produção foram ajustados com relação ao "stand", de acordo com a fórmula desenvolvida por ZUBER (1942):

$$
\text { P.C.C. }=\text { P.C. } \frac{H-0,3 F}{H-F} \text {, onde, }
$$

P.C.C. = Peso de campo corrigido

P.C. = Peso observado no campo

$H=$ "stand" ideal (50 plantas, no caso)

$F=$ Nümero de falhas

Esta fórmula é de uso geral em ensaios de milho 
e leva em consideração a competição entre as plantas de. cada fileira. O ajuste através dessa fórmula adiciona 0,7 da prodü ção média para cada falha e considera que 0,3 é recuperado pe10 aumento de produtividade das plantas vizinhas à falha.

os dados de produção foram tambēm corrigidos com relação ao teor de umidade dos grãos, para uniformizá-1os em torno de um nível pré-determinado de umidade, uma vez que diferenças na umidade podem provocar diferenças importantes na produção. A correção foi realizada de acordo com a seguinte fórmula:

$$
\text { P.C. }(15,5 \%)=\frac{\text { P.C. }(1-U)}{(1-0,155)}, \text { onde, }
$$

P.C. $(15,5 \%)=$ Peso seco corrigido para $15,5 \%$ de umidade P.C. = Peso de campo observado

$\mathrm{U}=$ Umidade observada

$(1-0,155)=$ Expressa a matēria seca quando a umidade $\bar{e}$ de $15,5 \%$

Após a correção dos dados com relação ao teor de umidade e antes da correção com relação ao "stand", foi cal culada a produção média por planta, considerando apenas o peso dos grãos.

Com base na colheita e nas determinações feitas no laboratório, foram ainda determinados o número de espigas 
por parcela, nümero médio de grãos por espiga e o peso médio do grão.

\subsubsection{Anālise estatistica}

Para cada caráter foi realizada, primeiramente, a anālise da variância, seguindo o esquema apropriado para o delineamento em Blocos ao Acaso, tendo-se dessa forma para cada caráter duas anāises da variância, referentes a cada ano de plantio.

Convēm ressaltar que foram realizadas transformações de dados, quando a natureza dos dados coletados assim o exigia. Assim, numero de folhas por planta, "stand", nümero de fileiras por espiga, número de grãos por fileira, nūmero mé dio de grãos por espiga e número de espigas por parcela foram transformados para $\sqrt{x}$, enquanto que numero de espigas por planta e acamamento foram transformados para $\sqrt{x+0,5}$.

Uma vez realizadas as anālises simples para cä da caráter, foram, então, realizadas as anälises conjuntas, com a finalidade de detectar os diferentes efeitos que poderiam estar mascarando a verdadeira expressão dos caracteres, sen do os principais efeitos os de anos e de interação entre trata mentos e anos. Foi adotado um esquema com um desdobramento bem detalhado, para separar os diferentes efeitos, de modo a possibilitar conclusões imediatas e precisas. 
Para a análise conjunta da variância utilizouse o seguinte esquema:

Repetições

Anos (A)

Tratamentos

Populações do Composto (C)

Testemunhas (Te)

C vs Te

A $\mathrm{X}$ T

C $\mathrm{X}$ A

Te $\quad x \quad A$

( $\quad$ vs Te $) \quad x \cdot A$

Erro Médio
18

1

5

2

2

1

5

2

2

1

90

A causa da variação "Populações do Composto" re fere-se aos tratamentos que foram separados do Dentado Composto SRR ơ Prolífico, ou seja, às Populações Brancä, Amarela e Intermediária.

Além do Teste F foi realizado ainda o Teste Dun can, tanto para anāilises simples como para as anā 1 ises conjun- 
tas da variância.

4.2. Determinação das características radiculares

4.2.1. Material e metodologia

Foi instalado um experimento, em canteiros de $\underline{a}$ reia, em estufa, com a finalidade de determinar os : seguintes caracteres:

- Peso total da planta aos 28 dias de idade

- Peso total de raizes

- Peso de raízes seminais

- Peso de raízes nodais

- Nūmero total de raízes

- Nūmero de raízes seminais

- Nūmero de raîzes nodais

- Porcentagem de raízes seminais

Para condução do experimento foi utilizado o de Iineamento Inteiramente Casualizado, com 5 repetições. 0 expe rimento ficou, assim, constituído de 30 parcelas, sendo cada parcela constituída de 7 sacos plästicos, dando um total de 210 sacos plásticos.

Cada saco plástico foi preenchido quase totalmente com areia, sendo em seguida alinhado no canteiro com os outros sacos. Na véspera e no dia da instalação do experimen- 
to, os sacos foram bem molhados com auxílio de uma mangueira. Foram então realizados, com auxílio de um furador especial, 으 rificios no centro dos sacos, com profundidade aproximada de $5 \mathrm{~cm}$, sendo então plantada uma semente por saco plástico.

\section{o experimento foi instalado" em setembro de 1977} e os sacos foram molhados diariamente pela manhã, sendo ao mes mo tempo realizadas observações sobre a germinação. A germina ção começou no $6 !$ dia após a instalação, tendo então início um procedimento especial. Foram colocados palitos de sorvete nos sacos plásticos de acordo com o dia da germinação. Então, no primeiro dia de germinação, os sacos cujas plantas germinaram receberam um palito, que foi introduzido firmemente na areia, próximo à borda do saco. Os sacos cujas plantas germinaram no segundo dia receberam dois palitos, os do terceiro dia recebe ram três palitos e assim por diante.

A razão deste procedimento está relacionada com o início das determinações das diferentes características. Pa ra realização da colheita e determinação das características radiculares, são contados 28 dias a partir da data de plantio ou 23 dias a partir da germinação. E mais indicado realizar as determinações contando 23 dias a partir da germinação, uma vez que permite maior uniformidade nas determinações, pois estar-se-á trabalhando com plantas da mesma idade. Se fôssem contados os dias a partir da data de plantio, ter-se-iam plantas de diferentes idades, o que poderia acarretar perda de pre 
cisão. A realização das determinações 23 dias após a germinação apresenta também a vantagem de distribuir o volume de tra balho, uma vez que são colhidos primeiro os sacos com um palito, no dia seguinte os sacos com dois palitos, e assim por diante. A contagem dos dias a partir da instalação implicaria em realizar as determinações todas em um dia somente, o que é muito dificil, devido ao grande volume de trabalho. A realiza ção do trabalho em mais dias implicaria em perdas adicionais de precisão, acarretando maiores aumentos de erro experimental.

Aproximadamente 15 dias após a instalação do ex perimento foram detectados sintomas de deficiências nutricionais nas plantas, apresentando estas amarelecimento e secamento da primeira folha. Houve então necessidade de aplicação de solução nutritiva às plantas de acordo com a seguinte fórmula:

me/litro

\begin{tabular}{lc}
$\mathrm{KH}_{2} \mathrm{PO}_{4}$ & 1 \\
$\mathrm{KNO}_{3}$ & 5 \\
$\mathrm{Ca}\left(\mathrm{NO}_{3}\right)_{2}$ & 5 \\
$\mathrm{MgSO}_{4}$ & 2 \\
$\mathrm{Micronutrientes}_{\text {EDTA }}$ & 1 \\
\hline
\end{tabular}

Foram preparados sempre 10 litros de solução nu tritiva, sendo aplicados diariamente, em média, 5 litros. Ob- 
servou-se após alguns dias de aplicação, a räpida recuperação das plantas, que passaram a desenvolver-se novamente de forma norma 1 .

Por volta de 3 dias antes do início da colheita e das determinações foi cortada a ägua, para que a areia secas se, para facilitar a coleta de raízes. Esses cuidados são de máxima importância, uma vez que areia úmida fica muito agregada às raízes, havendo possibilidade de perda de parte do siste ma radicular quando da retirada das plantas dos sacos plásticos.

A germinação variou, havendo parcelas com 6,7 ,

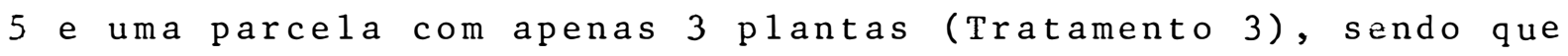
esta última foi eliminada. Como, com exceção da eliminada, to das as parcelas apresentaram pelo menos 5 plantas, foram utili zadas 5 plantas por parcela para realização das determinações.

As determinações foram realizadas em fins de setembro e início de outubro, sendo feitas por parcela, ou seja, cada parcela separadamente da outra para evitar enganos. os sacos plásticos foram tomados e abertos lateralmente e no fundo com o auxílio de um bisturi ou de uma lâmina de barbear, deixando-se a areia escorrer lentamente para não prejudicar a planta. Uma vez liberada a planta, foram então feitas as contagens de número de raízes seminais e nodais. Após a contagem, embrulhou-se as raízes seminais separadamente em jornal, a seguir embrulhou-se o restante da planta (raízes nodais + 
parte aérea) juntamente com o embrulho contendo as raízes semi nais em uma folha de jornal, sendo adicionada uma etiqueta con tendo a data das determinações e o nümero da parcela.

As plantas ficaram embrulhadas por um mínimo de 24 horas para que ocorresse homogenização da umidade, sendo re alizadas então as diferentes pesagens. Uma vez tomadas todas as medidas, foram iniciadas as anālises estatísticas.

\subsubsection{Anālise estatística}

Houve necessidade de realizar transformações nos dados experimentais. Assim os dados de peso.total da plan ta, peso total de raízes, peso de raízes nodais e peso de raízes seminais foram transformados para $\sqrt{x+0,5}$, os dados de número total de raízes, nümero de raízes nodais e nūmero de ra izes seminais foram transformados para $\sqrt{x}$ e os dados de porcentagem de raizes seminais foram transformados para arcseñ. Uma vez transformados os dados, foi feita a análise da variância, segundo o esquema do delineamento Inteiramente Casualizado, realizando-se ainda o Teste Duncan.

4.3. Testes de vigor

A determinação do vigor apresenta algumas difi culdades, uma vez que não existem testes padronizados e especí 
ficos para se poder afirmar que um lote de sementes apresenta uma determinada porcentagem de vigor. A determinação do vigor é feita de modo comparativo, é feita comparando-se um lote de sementes com outro lote de sementes. Assim, para se poder $\underbrace{--}$ zer melhores comparações, decidiu-se fazer mais um teste, para poder ter maior base para tirar conclusões mais precisas.

\subsubsection{Teste padrão de germinação}

\subsubsection{Material e metodologia}

Com auxílio de um germinador, foi realizado um teste padrão de germinação, em delineamento Inteiramente Casua 1 izado, $\operatorname{com} 4$ repetições.

Foram utilizadas 50 sementes por repetição e, có mo substrato foi usado o rolo de papel toalha. Antes da insta 1 ação deixou-se as folhas de papel toalha em um recipiente com àgua corrente por um período de 24 horas, para eliminação de impurezas e substâncias químicas estranhas que possam afetar negativamente a germinação das sementes. Para semeadura tomou se duas folhas de papel toalha e semeou-se as sementes em espa çamento uniforme, para evitar que uma semente prejudicasse a germinação da outra. Após a semeadura cobriu-se o conjunto com outra folha de papel toalha e com o auxilio de um aspersor molhou-se bem o conjunto. A seguir, enrolou-se bem o conjunto de tal forma que houvesse a formação de um rolo bem fino e a- 
pertado para que as sementes não pudessem escapar. Este pro cedimento foi repetido para cada um dos 24 rolos componentes do experimento, sendo cada rolo considerado como uma parcela. Quando todos os rolos estavam devidamente preparados, foram então colocados em um recipiente especial em posição vertical e, finalmente, colocados no germinador. Para evitar desidrata ção excessiva da parte superior dos rolos foi colocado um pano bem ümido sobre estas. O germinador foi regulado para $30{ }^{\circ} \mathrm{C}$, mantendo-se a umidade no germinador por volta de 90-95\%. Foram realizadas duas contagens: a primeira no 5 o dia e a segunda no 89 dia a partir da instalação, que foi feita em fins de outubro de 1976 .

Na primeira contagem, os rolos foram abertos e feita a contagem de plântulas normais e anormais, sendo os nümeros anotados. As sementes ainda não germinadas foram deixadas e os rolos foram novamente colocados no germinador. Na se gunda contagem, foram contadas as sementes que ainda germina ram e computadas as sementes mortas e as sementes dormentes. As contagens e a classificação das plântulas como normais ou a normais foram realizadas de acordo com as prescrições das Regras para Anälise de Sementes (1967), elaboradas pelo Ministērio da Agricultura.

4.3.1.2. Anālise estatîstica

o teste padrão de germinação serviu como base 
para outro teste de vigor, uma vez que a la. contagem do teste padrão de germinação é considerada como sendo um teste de vigor. Para realização das anāilses da variância da 1a. contagem e do teste padrão de germinação, transformou-se os dados para arcsen $\sqrt{\%}$. Para anāilse dos dados foi utilizado o esquema idealizado para o delineamento Inteiramente Casualizado, sen do feitos ainda alguns desdobramentos para maior detalhamento dos efeitos, conforme mostra o seguinte quadro:

Causas da Variação

G. L.

Trat amentos

5

Populações do Composto (C)

Testemunhas ( Te)

2

C vs Te

1

Residuo

18

Tota 1

23

Além do Teste F foi ainda realizado o Teste

Duncan.

4.3.2. Teste de emergência no campo

4.3.2.1. Material e metodologia

0 teste de emergência no campo, tambēm considerado um teste de vigor, foi instalado em canteiros de areia em 
estufa. Como delineamento experimental utilizou-se o Inteiramente Casualizado com 4 repetições. Foram plantadas 50 semen tes por parcela, em profundidade padrão de plantio e, em espaça mento entre sementes bem uniforme para evitar que uma semente influíse negativamente na germinação da semente vizinha.

Os canteiros foram regados diariamente e foram realizadas contagens diariamente e anotado o nümero de plântulas emergidas em cada dia. Essas observações diārias foram efetuadas até que todas as parcelas apresentaram nümero constante de plantas durante um período de três dias, sendo então computado o "stand" final, o qual também é considerado uma medida do vigor das sementes.

\subsubsection{Anāitise estatistica}

o experimento foi instalado em fins de outubro de 1976, tendo sido realizadas 10 contagens de emergência. Para cālculo da velocidade de emergência utilizou-se a seguinte expressão:

$$
\mathrm{VE}=\frac{\mathrm{N}_{1}}{\mathrm{D}_{1}}+\frac{\mathrm{N}_{2}}{\mathrm{D}_{2}}+\frac{\mathrm{N}_{3}}{\mathrm{D}_{3}}+\cdots \cdots \cdots+\frac{\mathrm{N}_{\mathrm{m}}}{\mathrm{D}_{\mathrm{m}}}
$$

Nesta fórmula $N_{1}$ refere-se ao nümero de plântulas emergidas no dia $1\left(D_{1}\right), N_{2}$ refere-se ao nümero de plântulas emergidas no dia $2\left(D_{2}\right)$ e, assim por diante. 
Com uso desta fórmula, calculou-se a velocidade de emergência para todas as parcelas, transformando, em segui da, os dados obtidos para $\sqrt{V E}$. Com os dados transformados, realizou-se a anālise da variāncia, seguindo o esquema do deli neamento Inteiramente Casualizado, realizando-se ainda o Teste Duncan.

A seguir, somou-se os valores de $\mathrm{N}_{(}, \mathrm{N}_{1}, \mathrm{~N}_{2}, \mathrm{~N}_{3}$, ..., $\mathrm{N}_{\mathrm{m}}$ ) para cada parcela, obtendo-se o "stand" final do teste de emergência no campo, o qual é outro parâmetro que permi te a avaliação de vigor de sementes. o "stand" final foi multiplicado por dois para obtenção da porcentagem de germinação sendo essa porcentagem transformada para arcsen $\sqrt{\%}$. Uma vez transformados os dados para arcsen $\sqrt{\%}$, foi feita a análise da variância, segundo o esquema do delineamento Inteiramente Casu alizado, realizando-se ainda o Teste Duncan.

4.3.3. Teste de envelhecimento räpido

\subsubsection{Material e metodologia}

Para a realização do teste de envelhecimento rạ pido, o qual foi instalado em fins de outubro, foram utiliza das 220 sementes de cada tratamento. As sementes foram distri buídas em recipientes apropriados e colocadas em uma câmara de vigor à temperatura de $42^{\circ} \mathrm{C}$ e $100 \%$ de U.R. (umidade relativa) por um período de 120 horas. Após esse período, as se- 
mentes foram retiradas da câmara de vigor e separadas em 4 re petições de 50 sementes.

Com essas sementes, foi então instalado um teste de germinação, seguindo-se a mesma metodologia utilizada no teste padrão de germinação, tendo como ünica modificação o fato de que foi realizada apenas uma contagem, sendo que esta foi realizada no 59 dia após a colocação do material no germinador.

\subsubsection{Anālise estatística}

Para realização da anālise estatística foram computados apenas os dados de plântulas normais. os dados foram transformados para arcsen $\sqrt{\%}$, sendo feita, então, a anāiise da variância, segundo o esquema do delineamento Inteiramente Casualizado. Além do Teste F foi realizado ainda o Teste Duncan . 


\section{RESULTADOS OBTIDOS}

os ensaios de produção e a determinação de caracteres relacionados foram conduzidos por dois anos consecuti $\operatorname{vos}(1975 / 76$ e $1976 / 77)$ para que pudesse ser feita uma avalia ção mais precisa do comportamento dos diferentes caracteres face às variações do ambiente. Foram realizadas análises simples da variância para cada ano, para cada um dos caracteres e com base nestas anālises simples foram realizadas as análises conjuntas, com desdobramento de algumas das causas da variação. Nas tabelas 1 a 4 , estão resumidos os resultados das aná lises conjuntas da variância, estando computados apenas os níveis de significância obtidos com a aplicação do Teste F. Ob serva-se que não se detectou, praticamente, diferenças entre as populações do composto, exceto para o caráter nümero de espigas por planta. Entre as testemunhas verificou-se bastante variação para a maioria dos caracteres determinados. 
portamento normal com relaçäo às variações do ambiente. Porém, segundo as tabelas 2 e 3 , os caracteres nümero de fileiras por espiga, tamanho da espiga, peso da espiga e peso do sabugo apresentaram efeito de interação entre anos, sendo que essa interação verificou-se somente entre as testemunhas.

A anāise da variância dos testes de vigor tam bém sofreu desdobramentos, para que se pudesse verificar se as diferenças encontradas eram devidas às populações do composto ou às testemunhas. Para melhor visualização das diferenças en contradas foi organizada a tabela 5, onde pode-se observar os níveis de significância detectados com a aplicação do Teste F. o grupo das testemunhas não apresentou variação significativa em todos os: testes realizados, ao passo que as populaçóes do composto apresentaram grande variação. A comparação entre os dois grupos de tratamentos apresentou significância estatistica.

Além das tabelas com os níveis de significância do Teste F, foram organizadas para ensaios de produção e deter minação de caracteres determinados dois tipos de tabelas para complementar e facilitar a anālise dos resultados obtidos. 0 primeiro tipo contém, para cada caráter, as médias de cada tratamento nos dois anos de plantio, as médias gerais dos dois anos para cada tratamento, os coeficientes de variação de cada ano e o coeficiente de variação médio. o segundo tipo contēm as comparações de médias e os níveis de significância detecta- 
dos pela aplicação do Teste Duncan para cada ano e para as mê dias gerais. Assim, as tabelas 6 a 52 apresentam os resulta dos gerais obtidos nos ensaios de produção e nas determinações de caracteres relacionados.

A produção foi analisada sob dois aspectos: pro dução com correção para "stand" e produção sem correção para "stand". Conforme as tabelas 6 a 9 , não se verificaram grandes diferenças entre as populações do composto sob os dois as pectos, sendo interessante ressaltar, entretanto, os coeficien tes de variação obtidos: 17,$98 ; 22,43$ e $20,6 \%$ no primeiro ano, segundo ano e média geral, respectivamente, com correção para "stand" e 11,98; 22,9 e 19,03\% sem correçäo para "stand". Estes coeficientes, pela sua magnitude, tem interesse nas considerações sobre a produção.

Ainda foram obtidos coeficientes de variação e levados para acamamento $(22,67 ; 31,65$ e $27,57 \%)$ na tabe 1 a 22 e para produção média por planta $(21,24 ; 22,65$ e $22,04 \%$ na tabe1a 40. Para o restante dos caracteres, os coeficientes obtidos são baixos, na maioria menores que $10 \%$.

Para este grupo de determinações, a População Branca apresentou resultados superiores para a maioria dos caracteres, sendo que para caracteres 1 igados aos grãos, como nū mero, peso e conformação, mostrou-se, de maneira geral, inferior. A característica época de florescimento, na tabela 52 , 
foi determinada apenas para o segundo ano de plantio

77), devido a falhas de metodologia verificadas no primeiro ano. A tabela 52 mostra que não houve diferenças entre as popu 1 ações do composto, apresentando ainda os resultados obtidos com a aplicação do Teste Duncan.

Para os caracteres produção com correção para "stand", produção sem correção. para "stand", produção média por planta, "stand" e espessura do grão, tanto o Teste F como o Teste Duncan não conseguiram detectar qualquer diferença sig nificativa. Para os caracteres nümero médio de grãos por espi ga, nümero de fileiras por espiga e peso do sabugo, o Teste F não conseguiu detectar diferenças significativas, entretanto, o Teste Duncan conseguiu detectar contrastes significativos,po rém não entre as populações do composto.

Para os caracteres restantes, o Teste F e o Tes te Duncan conseguiram detectar diferenças significativas. Foram detectadas diferenças somente entre as testemunhas e das populações do composto com relação às testemunhas. As populações do composto mostraram comportamento uniforme, exceto para o caráter número de espigas por planta, onde as testemunhas não apresentaram variação e a Populạção Branca apresentou dif́e renças significativas com relação à População Amarela.

Nas tabelas 53 a 57 encontram-se os resultados relativos aos testes de vigor, em forma de médias e resultados decorrentes da apIicação do Teste Duncan. Os testes de vigor 
foram realizados em um ano apenas, devido ao grande controle ambiental envolvido neste tipo de determinação. Dessa forma, os dados obtidos aproximam-se bastante de seus valores re ais, havendo menor indice de mascaramento. Em todos os testes de vigor realizados, observa-se grande uniformidade entre as testemunhas, ao passo que as populações do composto apresentam variação significativa. A População Branca mostrou superioridade em todos os testes de vigor realizados, em relação às Populações Amarela e Intermediāria, como se pode observar nas tabelas 53 a 57 .

Em termos de médias, as testemunhas mostraram os melhores resultados. Entre as populações do composto, a Po pulação Branca também mostrou diferenças significativas com a aplicação do Teste Duncan, como se pode observar nas tabelas 53 a 57 . Nestas mesmas tabelas, pode-se ver que os coeficientes de variação obtidos são satisfatórios, variando de $2,3 \%$ para o teste de velocidade de germinação, a 6,81\% para o "stand" final do teste de emergência no campo.

Assim como para os testes de vigor, as determinações de características radiculares foram efetuadas em um a no apenas, uma vez que foram realizadas em estufa. As médias, os coeficientes de variação, o Teste Duncan e o Teste F encon tram-se nas tabelas 58 a 65 , tendo-se assim um quadro geral do comportamento dos tratamentos com relação às características radiculares. Entre as populações do composto, a População 
Branca apresentou resultados mais baixos para quase todos os caracteres, exceto para os caracteres nūmero de raízes seminais e porcentagem de raízes seminais, em termos de méaias.

Ainda em termos de médias, entre as populações do composto, a População Intermediāria apresentou superioridade para os caracteres peso total da planta aos 28 dias de idade, peso total de raízes, peso de raízes nodais e peso de raí zes seminais, enquanto que a População Amarela mostrou-se supe rior para número de raízes nodais e número total de raízes.

Para os caracteres peso total de raízes, peso de raízes seminais, número de raízes seminais e porcentagem de raízes seminais, tanto o Teste F como o Teste Duncan não detectaram qualquer diferença significativa entre os seis tratamentos, ao passo que para os outros caracteres foram encontradas diferenças, embora somente entre as testemunhas.

os coeficientes de variação encontrados varia ram de 3,19\%, para nümero total de raízes, a 14,94\%, para peso de raízes nodais. i Para três caracteres foram encontrados coe ficientes de variação superiores a $10 \%$, o que para experimentos com grande controle ambiental é um tanto alto.

Foram organizadas ainda as tabelas 66,67 e 68, onde se encontra uma relação de todos os caracteres determinados e a marcação dos diferentes caracteres para os quais cada população mostrou superioridade em relação às outras, para uma 
.68 .

melhor visualização das caracteristicas gerais de cada população. 


\section{DISCUSSÃO DOS RESULTADOS}

De acordo com os dados obtidos em todas as determinações realizadas, observa-se que não houve, praticamente, diferenças significativas entre as populações do composto, exceto para os testes de vigor, enquanto que para as testemunis ocorreram grandes diferenças para a maioria dos caracteres. As sim, entre materiais de mesma origem não se verificaram quase diferenças, enquanto que entre materiais de diferentes origens as diferenças foram grandes, o que jā era esperado devido às diferenças de germoplasma entre os tratamentos utilizados no presente traba1ho.

As populações do composto, originárias de uma mesma população base, não sofreram qualquer melhoramento inicial com relação à coloração da semente, de modo que qualquer superioridade que fosse detectada seria atribuída a combinações gênicas superiores presentes e relacionadas com a cor da população em questão. Entretanto, não se verificaram quais- 
quer diferenças significativas entre as populações, excẹtuando os testes de vigor, o que deve ser atribuído a frequências genicas e conteūdo gênico comuns às três populações.

Na verdade, foram encontradas diferenças, mostrando que cada população tem características que a diferencia das outras, sendo, entretanto, no geral, estas diferenças não significativas, uma vez que as três populações apresentaram comportamentos muito semelhantes. Dessa forma, as frequências das diferentes combinações gênicas são semelhantes para as três populações.

Entre materiais de diferentes origens, como é o caso das testemunhas, ou melhor, como é o caso dos tratamentos em si, foram verificadas diferenças significativas e isto é devido a diferentes fatores. $\bar{E}$ necessärio considerar, em primeiro lugar, que os materiais de origem dos tratamentos apresentaram, provavelmente, diferenças importantes nas frequências gênicas e no conteūdo gênico. A seguir, é necessārio con siderar que os materiais sofreram diferentes níveis de melhora mento e melhoramento em diferentes direções alẻm da produção. Dessa forma, há diferenças na altura da planta e da espiga, ta manho e diâmetro da espiga, etc... Espera-se, assim, que realmente ocorram grandes diferenças entre os tratamentos, uma vez que cada um teve origem de diferentes populações com diferentes potenciais a serem explorados. 
A 1 iteratura cita diferenças entre milinos brancos e amarelos de mesma origem, o que, provavelmente, é devido a diferenças nos níveis de melhoramento entre as populações. Provavelmente, uma das populaçōes, a branca óu a amarela, sofreu mais melhoramento genético do que a outra, resultando daí as diferenças constatadas. Isso é bastante provāvel, uma vez que as populações brancas e amarelas com o mesmo nível de recombinação não apresentaram diferenças significativas, conforme ocorreu no presente trabalho. As diferenças entre milhos brancos e amarelos de diferentes origens, conforme citações da literatura, são esperadas pelos mesmos motivos acima expostos.

Embora não tenham sido calculados coeficientes de correlação, tanto ao nível genético como ao nível fenotípico, a literatura a este respeito é bastante extensa. Apesar de não terem sido detectadas diferenças significativas entre as populações do composto para a maioria dos caracteres, a ana lise das médias indica diversas relações e tendências entre os diferentes caracteres. Com base nas informações fornecidas pe 1 a literatura e nas relações e tendências indicadas pelos dados obtidos, muitas considerações interessantes podem ser fei tas.

Comparando-se as três populações, do composto em relação aos caracteres determinados, observa-se que a População Branca apresentou resultados superiores em relação às outras duas populações para a maioria dos caracteres. Apesar de 
as diferenças entre as populações do composto não terem sido significativas, cada população apresenta características que, de certa forma, a diferencia das demais.

A População Branca apresentou plantas mais a1tas, espigas mais altas e maior número de folhas por planta, tendo apresentado também maior nümero de espigas por planta, entretanto, essa superioridade será discutida sob outro contexto.

Apesar de a produção das três populações não ter apresentado diferenças significativas, há uma pequena ten dência de superioridade da População Branca. Entretanto, em decorrência das pequenas diferenças encontradas e no valor re1 ativamente alto dos coeficientes de variação, torna-se muito dificil a formulação de conclusões decisivas a respeito de superioridade de uma ou de outra população e da relação da produ ção com os outros caracteres determinados.

Com relação aos caracteres da espiga e dos grãos, a População Branca apresentou espigas maiores, com maior diâmetro, maior nūmero de fileiras por espiga, nūmero de grãos por fileira intermediário, maior peso da espiga e maior peso do sabugo. Entre as três populações apresentou peso intermediário dos grãos, nümero intermediário de grãos por espi ga, grãos mais compridos, largura e espessura intermediárias e produção média por planta intermediária. 
A População Amarela apresentou menor número de fileiras por espiga, maior número de grãos por fileira, menor tamanho da espiga, menor diâmetro da espiga, peso intermediário da espiga, menor peso do sabugo, maior nümero de grãos por espiga, menor produção média por planta, menor peso dos grãos, comprimento intermediário dos grãos, menor largura e es pessura dos grãos.

A População Intermediária apresentou nümero de fileiras por espiga intermediário, menor número de grãos por fileira, tamanho e diâmetro da espiga intermediários, menor pE so da espiga, peso do sabugo intermediário, menor número médio de grãos por espiga, maior produção média por planta, maior pe so dos grãos, menor comprimento do grão, largura e espessura do grão maiores.

Estas características estão bastante relaciona das entre si. Assim, espigas maiores e mais grossas apresenta ram maior número de fileiras por espiga e sabugos mais pesados. Estes dados concordam com os trabalhos de WILLIAMs et alii (1965) e HALLAUER e WRIGHT (1967), que encontraram correlação genética positiva entre diâmetro da espiga e número de fileiras por espiga. Espigas com grande número de fileiras por espiga apresentaram grãos mais compridos e menos largos, sendo que a espessura dos grãos mostrou ser mais dependente do número dé grãos por fileira. 
Espigas com sabugos pesados apresentaram grãos mais leves, nümero pequeno de grãos por espiga e pequena produ ção média por planta, em relação ao tamanho e diâmetro da espi ga, o que sugere que a População Branca desperdiça muita energia na produção do sabugo em detrimento da jprodução de grãos. Esta tendência se cọnfirma ao observarmos a População Intermediária que produziu espigas de tamanho e diâmetro apreciáveis, com sabugo de peso satisfatório, menor produção de grãos, porém grãos mais pesados, mais largos e mais espessos.

A População Amarela produziu espigas menores e mais finas, com grande produção de grãos, sabugo mais leve e grãos menores e mais leves. Produção muito grande de grãos conduz a grãos menores. Assim, nestas condições, hão há influ ência negativa do sabugo e sim do número excessivo de grãos. Estas tendências concordam com as análises de caracteres do grão e da espiga realizadas por GRANTHAM (1917) e por BRUNSON e WILLIER (1929).

Apesar de não ser possível a formulação de conclusões decisivas a respeito de relações da produção com os outros caracteres determinados, pode-se verificar pela análise dos dados algumas tendências que estão de acordo com as informações fornecidas pela literatura. Assim, a População Branca apresentou tendência de atingir maiores produções do que as Po pulações Amarela e Intermediária. Os dados indicam tendência de relação positiva de tamanho, diâmetro e peso da espiga com 
a produção, o que está de acordo com Love (1912), GRANTHAM (1917), HUTCHINSON e WOLFE (1918), RICHEY (1925), JENKINS(1929) LINDSTROM (1935), CAMPOS (1966), HALLAUER e WRIGHT (1967), TAVARES e ZINSLY (1971) e SHEHATA (1975).

0 peso do grão mostrou ser relacionado com a produção, principalmente no caso da População Amarela, que pro duziu o maior número de grãos por espiga, grãos mais leves e menor produção média por planta. Os trabalhos de BRUNSON e WILLIER (1929), HOEN e ANDREW (1959), WILLIAMS et alii (1965), CAMPOS (1966), ELROUBY e PENNY (1967) e QUEIROZ (1969) constataram correlações positivas e significativas entre peso do grão e produção.

Os caracteres dos grãos, como comprimento, 1argura e espessura, não mostraram relação direta com a produção, o que concorda com BRUNSON e WILLIER (1929). Esses caracteres mostraram ser mais dependentes e ter mais relação com caracteres como número de fileiras por espiga, nümero de grãos por fileira, tamanho e diâmetro da espiga.

0 peso do sabugo mostrou forte tendência de estar negativamente relacionado com a produção, uma vez que entre os caracteres de grãos e da espiga, mostrou ter influência negativa sobre o peso e o número de grãos da espiga. Caracte res como altura da planta, altura da espiga e número de folhas por planta parecem ter relação positiva com a produção, 
uma vez que a População Branca apresentou superioridade para estes caracteres. Resultados semelhantes foram encontrados por diversos autores, estando entre eles GARNER e ALLARD (1920), ROBINSON et alii (1951), MURTY e ROY (1957), JUGENHEIMER (1958), LOOMIS e WILLIAMS (1963), CAMPOS (1966), ELROUBY e PENNY (1967), HESKETH et alii. (1969), TAVARES e ZINSLY (1971) JOHNSON (1973) e SHEHATA (1975).

Observa-se, assim, que cada população do compos to tem caracteristicas distintas, que a diferencia das demais. A População Branca tem como principal característica as plantas altas, espigas altas, grandes, grossas e pesadas. Tem ainda sabugos pesados e grãos leves e compridos, além de peque na produção de grãos por plänta em relação ao tamanho das espi gas. A População Amarela tem plantas de altura intermediária, espigas menores e mais finas, grande produção de grãos, sendo estes, entretanto, menores e leves. A População Intermediāria apresentou as plantas mais baixas entre as três populações do composto, espigas de tamanho e diâmetro intermediários, porém mais leves. Apresentou também maiores produções médias por planta, com grãos curtos, largos, espessos e mais pesados. As sim, comparando-se as três populações do composto, apesar da inexistência de significância, nota-se que a População Branca apresenta tendências em direção à superioridade.

o caráter nümero de espigas por planta apresenta-se correlacionado com a produção, conforme ficou evidencia 
do em inúmeros trabalhos como nos de JENKINS (1929), BRUNSON e WILLIER (1929), ROBINSON et alii (1951), HOEN e ANDREW (1959), GOODMAN (1965), CAMPOS (1966), LONNQUIST et alii. (1966), VILLA NO (1966), QUEIROZ (1969) e SHEHATA (1975). No presente trabalho, o caräter nümero de espigas por planta mostrou variaçäo significativa unicamente entre as populą̧ós do composto, con ferindo superioridade à População Branca. A aplicação do Teste de Duncan (tabela 17) mostrou diferenças significativas entre as Populações Branca e Amarela.

Essa superioridade da População Branca, entretanto, uma vez que não foi expressa em caracteres relacionados como número de espigas por parcela, não corresponde totalmente à realidade. A sobrevivêncía final dos seis tratamentos não foi muito diferente nos dois anos, não tendo havido também diferenças significativas para o caräter nümero de espigas por parcela, embora o hỉbrido duplo HDmd-7974 tenha apresentado número de espigas por parcela bastante superior ao de outros tratamentos. Assim, a População Branca apresentou maior número de espigas por planta nos dois anos, sem expressar essa su perioridade em caracteres relacionados.

O motivo dessa discrepância reside; provavelmen te, em problemas de amostragem, uma vez que a determinação des te caráter é feita em 10 plantas competitivas de cada parcela, escolhidas aleatoriamente. A determinaçãofeita dessa forma permite que ocorram erros, levando-se em consideração, princi 
palmente, a grande variabilidade do composto e a uniformidade dos materiais híbridos. Para uniformizar a determinação de ca racteres deste tipo e diminuir a fonte de erro, seria melhor fazer a determinação em todas as plantas da parcela, ao invés de escolher 10 plantas competitivas aleatoriamente. Dessa forma, eliminar-se-ia o perigo de obter resultados errôneos e o perigo ainda maior de formular conclusões não condizentes com a realidade.

Para os caracteres número de fileiras por espi ga, tamanho da espiga, peso da espiga e peso do sabugo, a anālise estatística detectou efeito significativo de interação entre anos, ao passo que para a maioria dos outros caracteres uma observação mais cuidadosia das tabelas mostrará pequenos e não significativos efeitos da interação entre anos. 0 mais interessante, porēm, é a ausência de interação entre anos entre as populações do composto, a não ser pequenos e não significativos efeitos para poucos caracteres e só detectáveis após minuciosa observação das tabelas.

As interações entre anos, tanto leves como significativas, manifestam-se essencialmente entre as testemu nhas, o que leva a interessantes considerações. De uma forma mais geral, verificou-se interação entre anos para materiais cuja principal característica è a uniformidade genética, ao passo que materiais desuniformes e de grande variabilidade não apresentaram tendências de sofrerem tal tipo de interação. 
A presença de variabilidade genética en níveis apreciāveis, além de ser necessäria para o sucesso de programas de melhoramento, é também necessāria para que as populações possam enfrentar com mais segurança as diferentes condi ções ambientais. Essa variabilidade genética confere às populações maior flexibilidade para se adaptar rapidamente às mais diferentes variações das condições ambientais, permitindo que as populações apresentem comportamento uniforme durante o decorrer dos anos. Entretanto, em materiais híbridos e sintéti cos essa variabilidade encontra-se drasticamente reduzida, uma vez que uma das caracteristicas mais importantes desses materiais é a uniformidade.

Assim, existirão anos favorāveis a um material e desfavoráveis a outros e vice-versa, propiciando assim o apa recimento de efeitos de interação entre anos. Para o aparecimento dessas interações existem caracteres mais sensíveis e ou tros menos às variações das condições ambientais, o que expli ca a manifestação de interações entre anos estatisticamente significativas para alguns caracteres e não significativas para outros.

o carāter nümero de fileiras por espiga mostrou relação muito pequena com a produção, entretanto, o fato de ser um carāter suscetível de sofrer interações entre anos dimi nue bastante a sua utilidade para programas de melhoramento. os dados para este carāter, estão muito de acordo com os obti- 
dos por HOEN e ANDREW (1959) que mostraram ser a correlação entre nümero de fileiras por espiga e produção de significância não consistente de um ano para outro, e por QUEIRoZ (1969) que encontrou correlação muito baixa para permitir previsões seguras em programas de melhoramento. Os caracteres tamanho da espiga, peso da espiga e peso do sabugo tem comportamento mais uniforme, apesar da interação, o que é devido a associações consistentes com a produção, como ficou evidenciado nos trabalhos de HUTCHINSON e WOLFE (1918), BRUNSON e WILLIER (... 1929), LINDSTROM (1935), HAYES e JOHNSON (1939), ROBINSON et alii (1951), CAMPOS (1966), HALLAUER e WRIGHT (1967), TAVARES e ZINSLY (1971) e SHEHATA (1975).

Os testes de vigor realizados mostraram, entre os seis tratamentos, uma grande superioridade das testemunhas sobre as populações do composto. Entretanto, entre as testemunhas não foram detectadas diferenças significativas, ao pas so que entre as populações do composto houve variação grande e significativa. A razão para a uniformidade entre variedade sintética e híbridos duplos reside no próprio processo de produção e nas exigências do mercado. Como o agricultor está in teressado em boas produções e como as boas produções estão relacionadas com um bom "stand", percebe-se que é necessārio que as sementes das variedades e híbridos apresentem bom poder ger minativo.

Dessa forma, as companhias de sementes só ven- 
dem lotes de sementes com bom vigor e excelente poder germinativo. Existem normas que regulam os mínimos exigidos para o poder germinativo, para que o lote de sementes seja 1 iberado. Assim, de certa forma, é feita pelas companhias de produção de sementes uma seleção para aumentar o poder germinativo, de modo que, no final, os materiais híbridos apresentem comportamen to uniforme e semelhante quanto a esse aspecto, mesmo sendo ma teriais provenientes das mais diferentes companhias produtoras de sementes. No caso das populações do composto isto não ocor re, uma vez que nunca foi feita seleção para este aspecto. As sim, existe grande variabilidade quanto aos atributos de vigor entre as populações do composto. BURRIS (1975) considera que variabilidade genética e heterose exercem também papel importante no grau de vigor de sementes, o que tem relação direta com as considerações feitas acima.

Entre as populações do composto verificou-se uma superioridade da População Branca em todos os testes realizados. A População Branca mostrou-se capaz de promover rápida e eficiente instalação das plantas no campo, uma vez que apresentou germinação alta e rápida. A População Intermediária a presentou os piores resultados nos testes de vigor, ficando a População Amarela em posição intermèdiária.

A População Branca mostrou também ter boa capacidade para resistir aos efeitos do armazenamento, uma vez que sofre menor deterioração do que outras populações, conforme 
mostram os resultados do teste de envelhecimento räpido. Este teste mede os efeitos da deterioração em sementes, sendo mais vigorosas as que menos sofrerem com o envelhecimento rápi do. Estes resultados concordam com GRABE (1966) que considera que sementes mais vigorosas sofrem menos deterioração durante períodos longos de armazenamento do que sementes menos vigorosas.

Dessa forma, a População Branca germina rapidä mente, apresentando plântulas fortes e vigorosas. Comparandose as três populações a partir do momento da semeadura, observa-se que a superioridade da População Branca se restringe aos estágios iniciais de desenvolvimento, sendo então igualada às outras duas populações. No aspecto geral, não existem diferen ças significativas entre as três populações a partir de determinado estágio de desenvolvimento.

Assim, os dados obtidos sugerem que o vigor só tem influência decisiva nos estägios iniciais de desenvolvimen to, permitindo germinação räpida e crescimento acelerado das plântulas. Não se obteve evidências de influências significativas do vigor sobre a produção, uma vez que a População Branca não obteve as maiores produções.

Entretanto, a ausência de influência do vigor sobre o desenvolvimento das plantas a partir de determinado es tägio de desenvolvimento pode ser devida à ausência de condi- 
ções ambientais anormais. ZINSLY e VENCOVSKY (1968) analisando a influência do tamanho da semente de milho sobre a produti vidade e sobrevivência das plantas, de materiais de diferentes origens, durante três anos, encontraram que sementes grandes e médias levam vantagem sobre sementes pequenas e, que para os caracteres "stand" final e produtividade por parcela as sementes grandes superaram as sementes médias. Existe uma rela ção entre tamanho de sementes e vigor, de modo que sementes grandes são mais vigorosas.

Em anos com condições ambientais anormais, é de se esperar que as sementes grandes apresentem superioridade so bre sementes menores, uma vez que devido ao maior vigor terão maiores condições de enfrentar as situações adversas. A Popu1 ação Branca apresentou sementes maiores, devendo-se esperar que em condições anormais ela tenha desempenho superior. Em condições normais, as três populações tem condições favorāveis para se desenvolverem, ficando o maior vigor, de certa forma, diluído. Condições anormais, principalmente nos estägios iniciais de desenvolvimento, deverão permitir que as sementes mais vigorosas apresentem melhor desenvolvimento, suplantando as demais, o que está de acordo com os trabalhos de GRABE (1966) e PAULI (1967).

A 'anālise das características radiculares também apresenta alguns aspectos interessantes, embora não tenham sido detectadas diferenças significativas para alguns carac- 
teres. SMITH e WALWORTH (1926) encontraram uma correlação positiva entre o nümero de raỉzes seminais e produção, o que es tá de acordo com as tendências encontradas no presente traba 1ho, uma vez que a População Bráca apresentou maior nümero de raízes seminais, apresentando ainda maior porcentagem de raizes seminais. Estes dados não concordam, entretanto, com os obtidos por COLLINS (1927) e por MANGELSDORF e GOODSELL(1929), que näo encontraram relação entre nümero de raízes seminais e produção.

A População Intermediária mostrou superioridade para a maioria dos caracteres radiculares determinados, sendo que a População Branca mostrou inferioridade em relação às outras duas populaçöes do composto. De modo geral, entre as populações do composto, a População Branca apresentou o sistema radicular mais pobre nos primeiros estágios de desenvolvimento o que, segundo ARAUJo (1975), é uma indicação de sistema radicular mais fraco na maturidade. Segundo este autor, sistema radicular forte e vasto nos primeiros estägios de desenvolvi mento é uma indicação de sistemas radiculares fortes na maturidade.

MANGELSDORF e GOODSELL (1929) determinaram que o nümero de ra ỉzes seminais não tem relação com tamanho, diâme tro e forma da espiga, nümero de fileiras por grãos, comprime $\underline{n}$ to e largura dos grãos, a 1 tura da planta e da espiga e acamamento. Os dados obtidos sugerem tendência de existir relação 
positiva entre nümero de raízes seminais e tamanho e diâmetro da espiga, comprimento do grão, altura da planta e da espiga e acamamento.

De maneira geral, entre os seis tratamentos, os caracteres radiculares nos estägios iniciais de desenvolvimento, aparentemente, não tiveram influência no comportamento das plantas na maturidade, apesar de que os tratamentos mais produ tivos tenham tido o sistema radicular mais pobre no início do desenvolvimento, exceto para os caracteres número de raízes seminais e porcentagem de raízes seminais, nos quais apresenta ram superioridade.

Os dados obtidos sugerem que não existe muita relação entre o vigor de sementes e as características radiculares, uma vez que os tratamentos mais vigorosos apresentaram sistemas radiculares mais pobres, mostrando inclusive, menores pesos de plantas aos 28 dias de idade, apesar de as diferenças não serem estatisticamente significativas. Os dados, entretan to, mostram uma certa tendência nesta direção, o que não concorda com os dados de SMITH e WALWORTH (1926), estando, porém, de acordo com os resultados obtidos por MANGELSDORF e GOODSELL (1929).

Interessante, tambēm, é o fato de as testemunhas terem apresentado os sistemas radiculares mais pobres, ten do sido as populações do composto superiores. Nos testes de vigor as testemunhas apresentaram os melhores resultados, ten- 
do sido superiores às populações do composto. Apesar de apre sentarem altos níveis de germinação e de vigor, desenvolveram sistemas radiculares muito pobres nos estágios iniciais de desenvolvimento. Estes dados sugerem que outros fatores, além do vigor, atuam nos estágios iniciais de desenvolvimento das plantas e que o vigor sō tem real importância na porcentagem e velocidade de germinação e na capacidade de armazenamento, passando a exercer importância secundária no desenvolvimento posterior das plantas. 


\section{CONCLUSOES}

As principais conclusões deste trabalho foram:

(1) A anālise da produção e dos caracteres rela cionados, apesar de não terem sido detectadas diferenças signi ficativas, indica uma tendência de superioridade da População Branca em relação às outras duas populações do composto.

$$
\text { (2) } 0 \text { caräter nümero de espigas por planta, }
$$
quando determinado a partir de uma amostra aleatória de plantas competitivas em cada parcela, apresenta importantes distor ções. 0 mais indicado seria a determinação do carāter em tó das as plantas da parcela, com o fim de evitar erros devido a amostragem.

(3) A População Branca tem como principal caraç teristica as plantas altas, espigas altas, grandes, grossase pesadas. Tem ainda sabugos pesados e grãos leves e compridos, alēm de pequena produção de grãos por planta em relação 
ao tamanho das espigas.

(4) As características de espiga e grãos da População Branca sugerem que esta desperdiça muita energia na produção do sabugo em detrimento da produção de grãos.

(5) Entre as populações do composto, a População Branca apresentou superioridade em todos os testes de vi gor realizados.

(6) A População Branca apresenta tendência de resistir melhor à deterioração causada por períodos prolongados de armazenamento, devido à superioridade demonstrada no teste de envelhecimento räpido.

(7) 0 vigor de sementes só teve influência decí siva nos estägios iniciais de desenvolvimento, não havendo nenhuma indicação de influência decisiva em estágios mais avança dos de desenvolvimento e na produção, em anos normais e no pre sente trabalho.

(8) A População Branca apresentou o sistema radicular mais pobre até o 289 dia de idade, entre as populações do composto, de acordo com as características radiculares determinadas, sendo que a População Intermediária apresentou os melhores resultados.

(9) Os dados obtidos sugerem que os caracteres 
radiculares nos estágios iniciais de desenvolvimento tem pouca ou nenhuma influência no comportamento das plantas na maturi dade.

(10) Os dados obtidos sugerem que não existe re lação entre vigor de sementes e as caracteristicas radiculares nos estágios iniciais de desenvolvimento, uma vez que os trata mentos mais vigorosos apresentaram os sistemas radiculares mais pobres. 
8. SUMMARY

This research was realized to determine if the colour of the seeds have any influence over the yielding capacity of white and yellow corn derived from a same original population. It was investigated also if any character of a large serie of determined characters, was contributing to the superiority or inferiority of the three populations of the research (white, yellow and intermediate).

The research was divided in three basic groups of determinations:yield trials and determinations of related characters, vigor tests and determination of root characters at 28 days after planting. The yield trials and the determination of related characters were conducted in two successive years, while the other two groups were conducted only one year.

In the first group of determinations the following characters were determined: yield, type of tassel, 
plant height, ear height, number of leaves per plant, number of ears per plant, stand, lodging, number of rows per ears, number of kernels per row, ear size, ear diameter, ear weight, cob weight, weight of 100 kernels, mean number of kernels per ear, mean yield per plant, number of ears per plot, mean weight of the kernel, kernel length, kernel breadth and kernel thickness.

The following vigor tests were realized:

standard germination test, rapid aging test and the field emergence test. Finally, the following root characters were determined: total plant weight 28 days after planting, total roots weight, weight of nodal roots, weight of seminal roots, number of nodal roots, number of seminal roots, total number of roots and percentage of seminal roots.

Examining the results, the following basic conclusions were formulated:

- The yield trials and the determination of related characters indicated a tendency of superiority of the white population in relation to the other two populations from the same original population. The general characteristics of the white population suggest that the population spends to much energy with the production of the cob in detriment of the grain production. The evaluation of the character number of ears per plant is more exact when realized at all the plants 
of the plot, instead of the determination of the character at 10 plants selected at random in each plot.

- The white population, among the populations separated from the same original population, showed superiority in all vigor tests. Showed also a tendency to have a greater resistance in front of the deterioration effects of large times of storage. It was also determined that the vigor have influence only at the first phases of development of the plants, having no influence at later phases and on the yield, in normal years.

- The white population, till 28 days after planting, showed the smallest root system, among the populations separated from the same original population, while the intermediate population showed the best root system. The results suggest that the root characteristics on the first phases of development of the plants have little or none influence over the behaviour of the plants at maturity, having also no relation with vigor of the seeds. 


\section{LITERATURA CITADA}

ALEXANDER, D.E., 1952. Relation of environment and position of ear to kernel row number in corn. Agron. Journ. Madison, $44: 430-433$.

ALLEONI, M.R.B., 1976. Variabilidade do sistema radicular em famílias de meios-irmãos, Composto Flint C, Zea mays L. In: Relatório Cientifico do Instituto de Genética, ESALQ, Piracicaba, p.4-6.

ANDREW, R.H., 1966. A technique for measuring root volume "in vivo". Crop Science, Madison, 6:384-386.

ARAUJO, N.M., 1975. Variabilidade do sistema radicular entre cultivares de milho (Zea mays L.). Piracicaba, ESALQ/USP, 72p. (Tese de Mestrado) 
BAUMAN, L.F., 1960. Relative yields of first (apical) ànd second ears of semi-prolific southern corn hybrids. Agron. Journ. Madison, 52:220-222.

BERGER, J., 1968. Maize production and the manuring of maize. Centre D'Étude de I'Azote 5 Geneva. $315 \mathrm{p}$.

BIGGAR, H.H., 1919. The relation of certain ear characters to yield in corn. Journ. Amer. Soc. Agron. Madison, 11:230$-234$.

BRASIL: Ministério da Agricultura, 1967. Equipe Técnica de Sementes e Mudas. Regras para Anälise de Sementes, Rio de Janeiro, ABCAR, $120 \mathrm{p}$.

BRUNSON, A.M. e J.G. WILLIER, 1929. Correlations between seed ear and kernel characters and yield of corn. Agron. Jour. Madison, 21:912-922.

BURRIS, J.S., 1975. Seedling vigor and its effect on field production of corn. 30 th Annual Corn \& Sorghum Research Conference. Washington, 30:185-193.

CAMPos, M.S., 1966. Efeitos da seleção entre e dentro de progênies de meios-irmãos em duas populações de milho. Pirací caba, ESALQ/USP, 42p. (Tese de Mestrado) 
CARMo, C.M., 1969. Avaliação em progênies de meios-irmãos em populações heterogêneas de milho (Zea mays L.). Piracicaba, ESALQ/USP, 48p. (Tese de Mestrado)

CHASE, S.S. E D.K. NANDA, 1967. Number of leaves and maturity classification in Zea mays L. Crop Science. Madison, $7: 431-432$

CLARK, L.E., 1963. Effect of various bags on viability and vigor of seed and subsequent effect of vigor on yield. Annual Report Int. Crop Imp. Assoc. (s.1.), 1962-1963: $133-136$

COLLINS, G.N., 1914. A drought-resisting adaptation in seedlings of Hopi Maize. J.Agr. Res. (s.1.), 1:293-302.

COLLINS, G.N., 1927. Yield and the number of seminal roots in maize. Jour. Amer. Soc. Agron. Madison, 19:466-467.

CUNNINGHAM, C.C., 1916. The relation of ear characters of corn to yield. Journ. Amer. Soc. Agron. Madison, 8:188-196.

DAVENPORT, E., 1907. Principles of Breeding. Ginn and Company, Boston: 453-472.

DELOUCHE, J.C. e W.P. CALDWELL, 1960. Seed vigor and vigor tests. Proc. Assoc. of Seed Anal. (s.1.), 50:124-129. 
DUNCAN, W.G. e J.D. HESKETH, 1968. Net photosynthetic rates, relative leaf growth rates and leaf numbers of 23 races of maize grown at 8 temperatures. Crop Science. Madison, $8: 670-674$.

DUNCAN, W.G.; W.A. WILLIAMS e R.S. LOOMIS, 1967. Tassels and the productivity of maize. Crop Science. Madison, $7: 37-39$.

DUNGAN, G.H. e C.M. WOODWORTH, 1939. Loss resulting from pulling leaves with tassels in detasseling corn. Journ. Amer. Soc. Agron. Madison, 31:372-875.

ELROUBY, M.M. e L.H. PENNY, 1967. Variation and covariation in high oil population of corn (zea mays L.) and their implications in selection. Crop Science. Madison, 7:216-219.

EWING, E.C., 1910. Correlations in corn. N.Y. Cornelz Agric. Exp. Sta. BulZ. New York, 287, 100 .

GARDNER, F.D., 1894. Field experiments with corn. IZZ. Agric. Exp. Sta. BuZz. Illinois, 37.

GARDNER, C.0., 1961. An evaluation of effects of mass selection and seed irradiation with thermal neutrons of corn. Crop Science. Madison, 1:244-245. 
GARNER, W.W. e H.A. ALLARD, 1920. Effect of the relative length of day and night and other factors of the environment on growth and reproduction in plants. J. Agr. Res. (s.1.), $18: 553-606$.

GERALDI, I.0., 1977. Estimação de parâmetros genéticos de caracteres do pendão em milho (Zea mays L.) e perspectivas de melhoramento. Piracicaba, ESALQ/USP, 103p. (Tese de Mestrado)

GRABE, D.F., 1966. Significance of seedling vigor in corn. 21st Hybrid Corn Industry Research Conference. Washington, $21: 39-44$.

GRANER, E.A., 1950. Genética da coloração amarela da semente de milho. Piracicaba, ESALQ/USP, 81p. (Tese de concurso para provimento efetivo da 4a. Cadeira Agricultura Especial e Genética Aplicada)

GRANTHAM, A.E., 1917. The relation of cob to other ear characters in corn. Jour. Amer. Soc. Agron. Madison, $9: 201-216$

GROGAN, C.0., 1956. Detasseling responses in corn. Agron. Jour. Madison, 48:247-249. 
GREEN, V.E., 1955. Associacion de altura de planta y cosecha en maiz tropical. Turrialba (s.1.), 5:83-90.

GOODMAN, M.M., 1965. Estimates of genetic variance in adapted and exotic populations of maize. Crop Science. Madison, 5:87-90.

HALLAUER, A.R. e J.A. WRIGHT, 1967. Genetic variances in the open-pollinated variety of maize, Iowa Ideal. Der Zuchter. Berlim, 37:178-185.

HAUGE, S.M., 1930. An inheritance study of the distribution of vitamin A in maize. Jour. of Biol. Chem. (s.1.), $86: 161-165$.

HAUGE, S.M. e J.F. TROST, 1928. An inheritance study of the distribution of vitamin A in maize. Jour. of Biol. Chem. $(s .1), 80:. 107-165$.

HAYES, H.K. e I.J. JOHNSON, 1939. The breeding of improved selfed lines of corn. Journ. Amer. Soc. Agron. Madison, $31: 250-255$.

HAYWARD, A.I., 1891. Report of the Agriculturist of Maryland for 1891. Maryland. 
HESKETH, J.D.; S.S. CHASE e D.K. NANDA, 1969. Environmental and genetic modification of leaf number in maize, sorghum and hungarian millet. Crop Science. Madison, 9:460-463.

HOEN, K. e R.H. ANDREW, 1959. Performance of corn hybrids with various ratios of flint-dent germplasm. Agron. Jour. Madison, 51:451-454.

HUTCHINSON, T.B. e T.K. WOLFE, 1918. Relation between yield and ear characters in corn. Jour. Amer. Soc. Agron. Madison, 10:250-255.

INGERSOLL, C.L., 1892. Detasseling corn. Nebr. Agr. Exp. Sta. Buzz. Nebraska, 20.

JENKINS, M.T., 1929. Correlation studies with inbred and crossbred strains of maize. J.Amer. Res. (s.1.), 39: $677-721$

JOHNSON, G.R., 1973. Diallel analysis of leaf area heterosis and relationships to yield in maize. Crop Science. Madison, 13:178-180.

JOHNSON, I.J. e E.S. MILLER, 1938. Variation in carotinoid pigment concentration among inbred and crossbred strains of corn. Cereal Chemistry (s.1.), 15:345-350. 
JONES, C.M., 1954. An inheritance study of corn maturity. Diss. Abs. (s.1.), 14:445-446.

JUGENHEIMER, R.W., 1958. Hybrid maize breeding and seed production. In: Food and Agriculture Organization of the United Nations. Rome, p.100-103.

KIESSELBACH, T.A., 1922. Corn investigations. Nebr. Agr. Exp. Sta. Res. BuzZ. Nebraska, 20.

KYLE, C.H. e H.F. STONEBERG, 1925. Associations between number of kernel rows, productiveness and deleterious characters in corn. J. Agr. Res. (s.1.), 31:83-99.

LEONARD, W.H. e T.A. KIESSELBACH, 1932. The effect of the removal of tassels on the yield on corn. Agron. Jour. Madison, 24:514-516.

LIABLE, C.A. e V.A. DIRKS, 1968. Genetic variance and selective value of ear number in corn (Zea mays L. I. Crop. Science. Madison, 8:540-543.

LINDSEY, M.F.; J.H. LONNQUIST e C.0. GARDNER, 1962. Estimates of genetic variance in open-pollinated varieties of cornbelt corn. Crop Science. Madison, 2:105-108. 
LINDSTROM, E.W., 1935. Genetic experiments on hybrid vigour in maize. Am. Nat. Chicago, 69:311-322.

LONNQUIST, J.H., 1961. Progress from recurrent selection procedures for the improvement of corn populations. Nebr. Agr. Exp. Sta. Res. Bulz. Nebraska, 197, 33p.

LONNQUIST, J.H., 1967. Mass selection for prolificacy in maize. Der Zuchter. Berlim, 37:185-188.

LONNQUIST, J.H.; O.A. COTA e C.0. GARDNER, 1966. Effect of mass selection and thermal neutron irradiation on genetic variances in a variety of corn (zea mays L.l. Crop. Science. Madison, 6:330-332.

LONNQUIST, J.H. e M. CASTRO, 1967. Relation of intrapopulation genetic effects to performance of $\mathrm{S}_{1}$ lines of maize. Crop Science. Madison, 7:361-364.

LOOMIS, R.S. e W.A. WILlIAMS, 1963. Maximum crop productivity: an estimative. Crop Science. Madison, 3:67-72.

LOVE, H.H., 1912. The relation of certain ear characters to yield in corn. Proc. Amer. Breed. Assoc. (s.1.), 7:29-40. 
LOVE, H.H. e J.B. WENTZ, 1917. Correlation between ear characters and yield in corn. Jour. Amer. Soc. Agron. Madison, $9: 315-322$.

MANGELSDORF, P.C. e G.S. FRAPS, 1931. A direct quantitative relationship between vitamin $A$ in corn and the number of genes for yellow pigmentation. Science. Washington, $73: 241-242$.

MANGELSDORF, P.C. e S.F. GOODSELL, 1929. The relation of seminal roots in corn to yield and various seed, ear and plant characters. Jour. Amer. Soc. Agron. Madison, $21: 52-68$.

MILls, A.A., 1893. Field experiments with corn. Utah Agr. Exp. Sta. BuzZ., Utah.

MURTY, G.S. e N.N. ROY, 1957. Study of the Indian collection of maize varieties with special reference to the relationship between yield and other characters. Indian Jour. Genet. and Plant Breed. Nova Delhi, 17:73-89.

. MUSICK, G.J.; M.L. FAIRCHILD; V.L. FERGASON e M.S. ZUBER, 1965. A method of measuring root volume in corn (Zea mays L.). Crop Science. Madison, 5:601-602. 
NASS, H.G. e M.S. ZUBER, 1971. Correlation of corn /Zea mays L.) roots early development to mature root development. Crop Science. Madison, 11:655-658.

NEAL, N.P., 1968. Maturity rating systems for corn hybrids. Proc. 23th Annual Hybrid Corn and Sorghum Research Conference. Washington, 23:45-53.

NEWMAN, J.S., 1893. Experiments with corn. S.C.Agr. Exp. Sta. Buzi. (s.1.), 14 .

NOZZOLINI, V., 1963. I1 numero delle foglie quale indice de11a lunghezza de1 periode vegetative nel mais. Maydica. Bergamo, 8:No. 1: Supp 1. 149: p.34.

OBILANA, A.T. e A.R. HALLAUER, 1974. Estimation of variability of quantitative traits in BSS by using unselected maize inbred 1ines. Crop Science. Madison, 14:99-103.

PATERNIANI, E. e J.R. ZINSLY, 1965. Efeito do melhoramento do milho no ciclo das plantas. Ciência e Cultura, são Paulo, $17: 146$

PAULI, A.W., 1967. Inbred stands - Seed vigor and use of hormones. 22 nd Hybrid Corn Industry Research Conference. Washington, $22: 45-48$. 
PAULSEN, E.F. e E.S. LIO, 1942. Sobre el contenido en? carotenoides de los maices argentinos. Jornadas Agronomicas y Veterinarias (s.1.), 1941:1-13.

PERRY, D.A., 1972. Seed vigour and field establishment. Hort. Abstr. (s.1.), 42:334-342.

PIMENTEL GOMES, F., 1970. Curso de Estatistica Experimental. Piracicaba, ESALQ/USP. Distr.: Nobel/SP. 430 p.

POLLOCK, B.M. e E.E. ROOS, 1972. Seed and seediing vigour. In: Seed Biology. Academic Press, New York, 1:314-376.

QUEIROZ, M.A., 1969. Correlações genéticas e fenotípicas em progênies de meios-irmãos de milho (Zea mays L.) e suas implicações com o melhoramento. Piracicaba, ESALQ/USP, 71p. (Tese de Mestrado)

RICHEY, F.D., 1925. Corn judging and the productiveness of corn. Jour. Amer. Soc. Agron. Madison, 17:313-318.

ROBINSON, H.F.; R.E. COMSTOCK e P.H. HARVEY, 1949. Estimates of heritability and degree of dominance in corn. Agron. Jour. Madison, 41:353-359. 
ROBINSON, H.F.; R.E. COMSTOCK e P.H. HARVEY, 1951. Genotypic and phenotypic correlations in corn and their implications in selection. Agron. Jour. Madison, 43:282-287.

SCONCE, H.S., 1911. Scientific corn breeding. Proc. of the Amer. Breed. Assoc. (s.1.), 7:43-50.

SHEHATA, A.H., 1975. Associations among metric attributes in varietal maize populations in relation to their future improvement. Egypt. Jour. Genet. and Cytol. Alexandria, 4:66-89.

SMITH, C.D.; J.T. BERRY e A.A. CROZIER, 1895. Detasseling corn. Mich. Agr. Exp. Sta. Bulz. Michigan, 125:37-40.

SMITH, L.H. e E.H. WALWORTH, 1926. Seminal root development in corn in relation to vigor of early growth and yield of crop. Jour. Amer. Soc. Agron. Madison, 18:1113-1120.

STEENBOCK, H., 1919. White corn vs yellow corn and a probable relation between the fat soluble vitamin and yellow plant pigments. Science. Washington, 50:352-353.

STEENBOCK, H. e P.W. BOUTWELL, 1920. Fat soluble vitamin. III. The comparative nutritive value of white and yellow maize. Jour. of Biol. Chem. (s.1.), 41:81-96. 
TAVARES, F.C.A. e J.R. ZINSLY, 1971. Correlações fenotípicas em variedades de milho e respectivos híbridos. In: Relatório Cientifico do Instituto de Genética, ESALQ, Piracicaba, p.159-167.

THIELE, P., 1899. Der Maisbau. Stuttgart, Eugen Ulmer.

WATSON, G.C., 1893. Detasseling corn. CornelZ Agr. Exp. Sta. BuZ2., 61 .

WILIIAMS, J.C.; L.H. PENNY e G.F. SPRAGUE, 1965. Fu11-sib and half-sib estimates of genetic variance in an open- pollinated variety of corn (Zea mays L.). Crop Science. Madison, 5:125-129.

WILLIAMS, C.G. e F.A. WELTON, 1915. Corn experiments. Ohio Agr. Exp. Sta. BuzZ., 282.

WILSON, H.K., 1930. Plant characters as indices in relation to the ability of corn strains to withstand lodging. Jour. Amer. Soc. Agron. Madison, 22:453-458.

WOLFE, T.K., 1924. A biometrical analysis of characters of maize and their inheritance. Va. Agric. Exp. Sta. Tech. BuzZ. (s.1.), 26 .

WOOdSTOCK, L.W., 1965. Seed vigor. Seed World, 97(5):6. 
VILLANO, R., 1966. Heterosis, accion genica y correlaciones de catorce variedades de maís en Colombia. Chapingo, México, Collegio de Post-Graduados, 70p. (Tesis de Maestro)

VRIES, H. de, 1901. Die Mutationstheorie. Leipsic, Vert \& Co.

ZINSLY, J.R. e R. VENCOVSKY, 1968. Influência do tamanho da semente do milho sobre a produtividade e sobrevivência das plantas. In: Relatório Cientifico do Instituto de Genética, ESALQ, Piracicaba, p.123-124. 
.108.

10. TABELAS 
Tabela 1 - Resultados da aplicação do Teste F para análise con junta da variância dos ensaios de produção e determinação de caracteres relacionados, conduzidos em dois anos de plantio

\begin{tabular}{lccccc}
\hline Caracteres & $\mathrm{R} *$ & $\mathrm{~A}$ & $\mathrm{~T}$ & $\mathrm{C} * *$ & $\mathrm{Te}$ \\
\hline Tipo de pendão & $\mathrm{ns}$ & $* *$ & $* *$ & $\mathrm{~ns}$ & $* *$ \\
Altura da planta & $\mathrm{ns}$ & $* *$ & $* *$ & $\mathrm{~ns}$ & $* *$ \\
Altura da espiga & $*$ & $* *$ & $* *$ & $\mathrm{~ns}$ & $* *$ \\
No de folhas/planta & $\mathrm{ns}$ & $* *$ & $* *$ & $\mathrm{~ns}$ & $*$ \\
No de espigas/planta & $\mathrm{ns}$ & $*$ & $*$ & $*$ & $\mathrm{~ns}$ \\
stand & $\mathrm{ns}$ & $\mathrm{ns}$ & $\mathrm{ns}$ & $\mathrm{ns}$ & $\mathrm{ns}$ \\
\hline
\end{tabular}

$$
\begin{aligned}
& \text { * - Repetições } \\
& \text { ** - Populações do Composto }
\end{aligned}
$$

Tipo de pendão

Altura da planta

Altura da espiga

No de folhas/planta

No de espigas/planta

stand n s

$\star \star$

$\star *$

$\star *$

**

n s ns

ns

n s

ns

ns

ns n s

n s

n S

n s

n s

n S

n s

n s

n S n s

n

n s

n $\mathrm{s}$
*

n s 
.110.

Tabela 2 - Resultados da aplicação do Teste F para anälise con junta da variância dos ensaios de produção e determinação de caracteres relacionados, conduzidos em dois anos de plantio

\begin{tabular}{|c|c|c|c|c|c|}
\hline Caracteres & $\mathrm{R} *$ & A & $\mathrm{T}$ & $C * *$ & $\mathrm{Te}$ \\
\hline Acamamento & ns & ns & * & ns & * \\
\hline No de fileiras/espiga & ns & ns & ns & ns & ns \\
\hline No de grãos/fileira & ns & ns & ns & ns & * \\
\hline Tamanho da espiga & ns & ns & * & ns & $\star *$ \\
\hline Diâmetro da espiga & ns & ns & $* *$ & ns & $* *$ \\
\hline Peso da espiga & ns & ns & ns & ns & ns \\
\hline
\end{tabular}

$$
\begin{aligned}
& * \quad \text { - Repetições } \\
& * * \text { - Populações do Composto }
\end{aligned}
$$

Caracteres

C vs $\mathrm{Te}$

A $\times \mathrm{T}$

C X A

Te $x$ A ( C vs Te)A

Acamamento

No de fileiras/espiga

No de grãos/espiga

Tamanho da espiga

Diâmetro da espiga

Peso da espiga ns

ns

ns

ns

*

ns ns

*

ns

*

ns

* ns

n s

ns

ns

**

ns

ns

ns

ns

ns

**

ns

n s

*

ns

ns

ns 
.111.

Tabela 3 - Resultados da aplicação do Teste r para análise con junta da variância dos ensaios de produção e determinação de caracteres relacionados, conduzidos em dois anos de plantio.

\begin{tabular}{|c|c|c|c|c|c|}
\hline Caracteres & $R *$ & A & $\mathrm{T}$ & $C * *$ & $\mathrm{Te}$ \\
\hline Peso do sagubo & $\mathrm{ns}$ & $\mathrm{ns}$ & $\mathrm{ns}$ & ns & $\mathrm{ns}$ \\
\hline Peso de 100 grãos & ns & $\mathrm{ns}$ & $* *$ & ns & $* *$ \\
\hline NQ mëdio grãos/espiga & ns & $\mathrm{ns}$ & ns & ns & $\mathrm{ns}$ \\
\hline Produção média/planta & ns & $\mathrm{ns}$ & $\mathrm{ns}$ & $\mathrm{ns}$ & ns \\
\hline No espigas/parcela & $\mathrm{ns}$ & $* *$ & ns & ns & * \\
\hline Peso médio do grão & $\mathrm{ns}$ & ns & $* *$ & $\mathrm{~ns}$ & $* *$ \\
\hline
\end{tabular}

$$
\begin{aligned}
& \text { * - Repetições } \\
& \text { * - Populações do Composto }
\end{aligned}
$$

Peso do sabugo

Peso de 100 grãos

No médio grãos/espiga

Produção média/planta

No espigas/parcela

Peso médio do grão

\section{ns}

$*$

ns

ns

ns

よ ns

ns

ns

ns

ns

ns n 5

n $s$

ns

ns

n s

ns

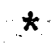

ns

s

n s

n s

ns

ns

ns

ns

ns 
Tabela 4 - Resultados da aplicação do Teste F para anälise con junta da variância dos ensaios de produção e determinação de caracteres relacionados, conduzidos em dois anos de plantio

\begin{tabular}{|c|c|c|c|c|c|}
\hline Caracteres & $R *$ & $\mathrm{~A}$ & $\mathrm{~T}$ & $C * t$ & $\mathrm{Te}$ \\
\hline Produção & ns & $\stackrel{1}{x}$ & $\mathrm{~ns}$ & $\mathrm{~ns}$ & ns \\
\hline Produção sem correção & ns & $\dot{x} *$ & n s & $\mathrm{ns}$ & $\mathrm{ns}$ \\
\hline Comprimento do grão & ns & $x+$ & $\therefore \dot{x}$ & $\mathrm{~ns}$ & $\dot{x} *$ \\
\hline Largura do grão & ns & \pm & $\approx x$ & $\mathrm{~ns}$ & $\mathrm{~ns}$ \\
\hline Espessura do grão & $\mathrm{ns}$ & $x^{2}+\hbar$ & $\mathrm{ns}$ & $\mathrm{ns}$ & $\mathrm{ns}$ \\
\hline
\end{tabular}

$\star \quad-$ Rejpetições

$\star *$ - Populações do Composto

Comprimento do gräo 
Tabela 5 - Resultados da aplicação do Teste F para anālise da variância dos testes de vigor

\begin{tabular}{lcccc}
\hline Testes & T* & C & Te & Te \\
Teste padrão de germinaço (TPG) & $* *$ & $*$ & ns & $* *$ \\
la. Contagem do TPG & $* *$ & $*$ & ns & $* *$ \\
Envelhecimento rápido & $* *$ & $* *$ & ns & $* *$ \\
Velocidade de emergência (VE) & $* *$ & $* *$ & ns & $* *$ \\
stand final da VE & & $* *$ & $*$ & ns
\end{tabular}

* Tratamentos 
Tabela 6 - Médias nos dois anos de plantio de experimentos em blocos ao acaso, médias gerais e coeficientes de va riação para o caráter produção.*

\begin{tabular}{lccc}
\hline Tratamentos & $1975 / 76$ & $1976 / 77$ & M.G. ** \\
\hline Branca & 5,6843 & 6,602 & 6,1433 \\
Amarela & 5,9836 & 6,1 & 5,9917 \\
Intermediária & 6,1332 & 6,237 & 6,1849 \\
Centralmex & 6,1644 & 7,258 & 6,7111 \\
Ag-152 & 5,6622 & 7,01 & 6,336 \\
HDmd-7974 & 6,0887 & 6,218 & 6,1536 \\
\hline CV $(\%) * *$ & 17,98 & 22,43 & 20,6 \\
\hline
\end{tabular}

$$
\begin{aligned}
& * \quad \text { Peso em Kg } \\
& * * \quad \text { Média Geral } \\
& * * * \quad \text { Coeficiente de variação }
\end{aligned}
$$


.115 .

Tabela 7 - Resultados da aplicação do Teste Duncan para o carạ ter produção.

M. G.

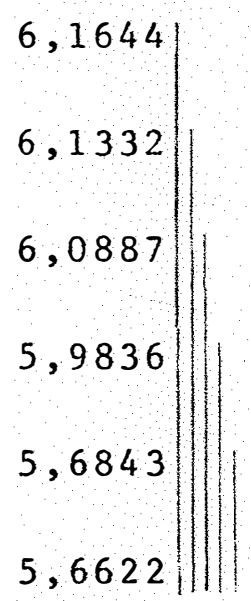

$\begin{aligned} & 7,258 \\ & 7,01 \\ & 6,602 \\ & 6,237 \\ & 6,218 \\ & 6,1\end{aligned} \mid$

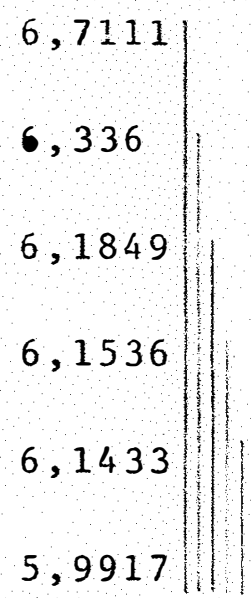


Tabela 8 - Médias nos dois anos de plantio de experimentos em blocos ao acaso, médias gerais e coeficientes de va riação para o caráter produção sem correção para "stand".

\begin{tabular}{lccc}
\hline Tratamentos & $1975 / 76$ & $1976 / 77$ & M.G. ** \\
\hline Branca & 5,1255 & 5,8918 & 5,5086 \\
Amarela & 5,2846 & 5,6421 & 5,4633 \\
Intermediäria & 5,0681 & 5,7394 & 5,4037 \\
Centralmex & 5,4357 & 6,6362 & 6,036 \\
Ag-152 & 5,1095 & 6,5456 & 5,8276 \\
HDmd-7974 & 5,6082 & 5,8868 & 5,7475 \\
\hline CV (\%) & $11 * 0$ & 22,9 & 19,03 \\
\hline
\end{tabular}

$$
\begin{aligned}
& * \quad \text { Peso em } \mathrm{Kg} \\
& * * \quad \text { Média geral } \\
& * * * \text { - Coeficiente de variação }
\end{aligned}
$$


.117.

Tabela 9 - Resultados da aplicação do Teste Duncan para o cará ter produção sem correção para "stand".

M. G .
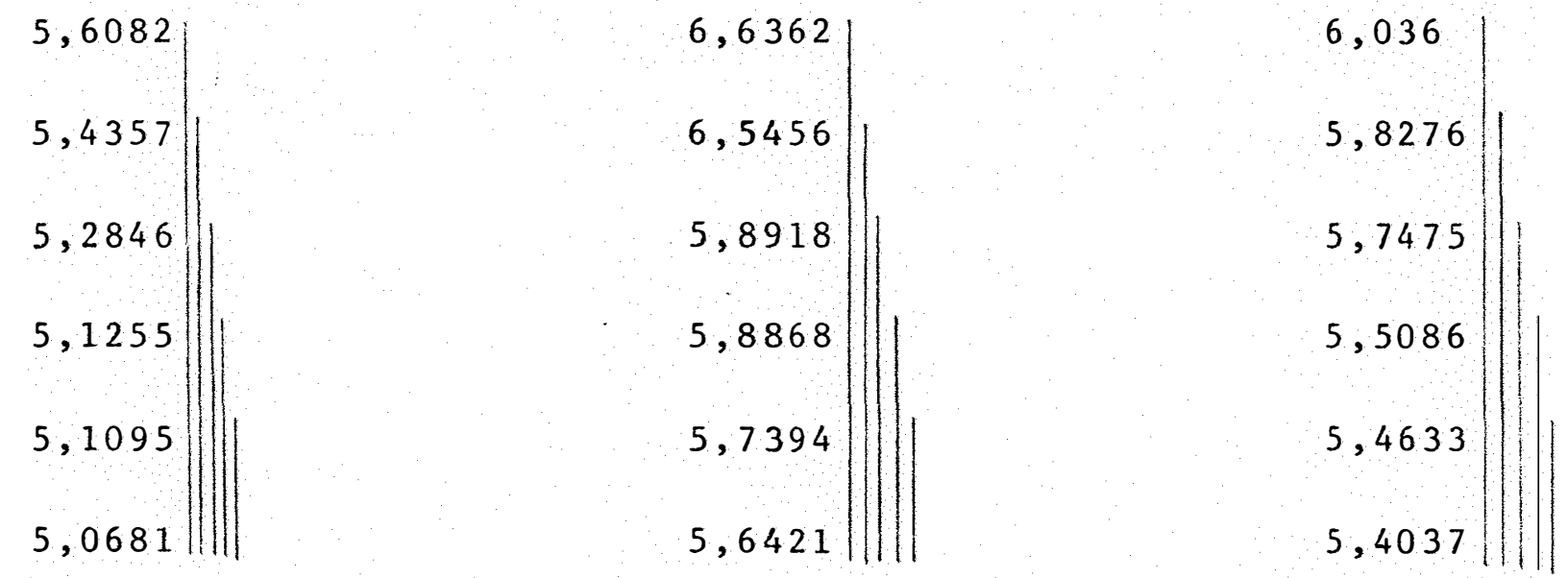
Tabela 10 - Médias nos dois anos de plantio de experimentos em blocos ao acaso, médias gerais e coeficientes de variação para o caráter altura da planta.

\begin{tabular}{lccc}
\hline Tratamentos & $1975 / 76$ & $1976 / 77$ & M.G. ** \\
\hline Branca & 2,6505 & 2,78 & 2,7152 \\
Amarela & 2,6145 & 2,706 & 2,6602 \\
Intermediária & 2,622 & 2,6955 & 2,6587 \\
Centralmex & 2,615 & 2,755 & 2,685 \\
Ag-152 & 2,295 & 2,536 & 2,4155 \\
HDmd-7974 & 2,4115 & 2,584 & 2,4977 \\
\hline CV (\%) & $3 * *$ & 6,00 & 4,92 \\
\hline
\end{tabular}

* - medidas em metros

** - média geral

$* * *$ - coeficiente de variação 
Tabela 11 - Resultados da aplicação do Teste Duncan para o caráter altura da planta.

\begin{tabular}{|c|c|c|}
\hline $1975 / 76$ & $1976 / 77$ & $M . G$. \\
\hline 2,6505 & 2,78 & 2,7152 \\
\hline 2,622 & 2,755 & 2,685 \\
\hline 2,615 & 2,706 & 2,6602 \\
\hline 2,6145 & $2,6955 \|$ & 2,6587 \\
\hline $2,4115 \|$ & 2,584 & 2,4977 \\
\hline 2,295 & 2,536 & 2,4155 \\
\hline
\end{tabular}


Tabela 12 - Médias nos dois anos de plantio de experimentos em blocos ao acaso, médias gerais e coeficientes de variação para o caráter altura da espiga.

\begin{tabular}{lccc}
\hline Tratamentos & $1975 / 76$ & $1976 / 77$ & M.G.** \\
\hline Branca & 1,591 & 1,782 & 1,6865 \\
Amarela & 1,5727 & 1,7035 & 1,6381 \\
Intermediäria & 1,574 & 1,719 & 1,6465 \\
Centralmex & 1,5575 & 1,673 & 1,6152 \\
Ag- 152 & 1,267 & 1,4515 & 1,3592 \\
HDmd-7974 & 1,4805 & 1,5905 & 1,5355 \\
\hline CV (\%) & & 8,18 & 6,99 \\
\hline
\end{tabular}

$$
\begin{aligned}
& * \quad \text { - medidas em metros } \\
& * * \quad-\text { média geral } \\
& * * * \quad \text { coeficiente de variação }
\end{aligned}
$$


Tabela 13 - Resultados da aplicação do Teste Duncan para o carāter altura da espiga.

\begin{tabular}{|c|c|c|}
\hline $1975 / 76$ & $1976 / 77$ & M.G. \\
\hline 1,591 & 1,782 & 1,6865 \\
\hline 1,574 & 1,719 & 1,6465 \\
\hline 1,5727 & 1,7035 & 1,6381 \\
\hline $1,5575 \|$ & 1,673 & 1,6152 \\
\hline 1,4805 & 1,5905 & 1,5355 \\
\hline 1,267 & 1,4515 & 1,3592 \\
\hline
\end{tabular}


Tabela 14 - Médias nos dois anos de plantio de experimentos em blocos ao acaso, mëdias gerais e coeficientes de variação para o caráter nümero de folhas por plan ta.

\begin{tabular}{lccc}
\hline Tratamentos & $1975 / 76$ & $1976 / 77$ & M.G. \\
\hline Branca & 3,9784 & 4,2025 & 4,0904 \\
Amarela & 3,9485 & 4,0955 & 4,022 \\
Intermediäria & 3,9731 & 4,187 & 4,08 \\
Centralmex & 3,9207 & 4,096 & 4,0083 \\
Ag-152 & 3,8814 & 4,0377 & 3,9595 \\
HDmd-7974 & 3,8348 & 3,9399 & 3,8873 \\
\hline CV (\%) & 1,48 & 2,69 & 2,2 \\
\hline
\end{tabular}

* - dados transformados para $\sqrt{x}$

** - média geral

*** - coeficiente de variação 
Tabela 15 - Resultados da aplicação do Teste Duncan para o caráter número de folhas por planta.

$1975 / 76 \quad 1976 / 77 \quad$ M. G.
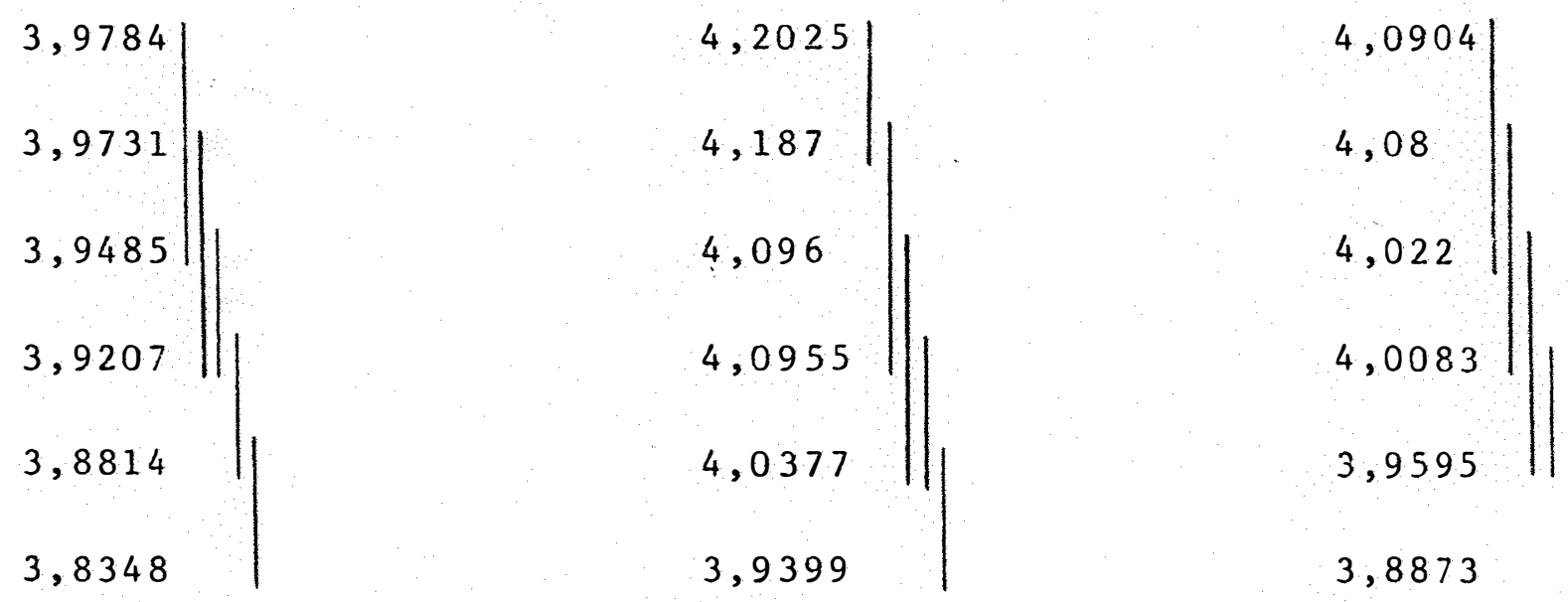
Tabela 16 - Médias nos dois anos de plantio de experimentos em blocos ao acaso, médias gerais e coeficientes de variação para o carāter número de espigas por plan $t a$.

\begin{tabular}{lccc}
\hline Tratamentos & $1975 / 76$ & $1976 / 77$ & M.G. ** \\
\hline Branca & 1,31 & 1,3939 & 1,3519 \\
Amarela & 1,2545 & 1,297 & 1,2757 \\
Intermediária & 1,2776 & 1,3489 & 1,3132 \\
Centralmex & 1,2365 & 1,256 & 1,2462 \\
Ag-152 & 1,2344 & 1,238 & 1,2362 \\
HDmd-7974 & 1,2632 & 1,3085 & 1,2858 \\
\hline CV $(\%) * *$ & 2,93 & 4,39 & 3,81 \\
\hline
\end{tabular}

$$
\begin{aligned}
& * \quad \text { - dados transformados para } \sqrt{x+0,5} \\
& * * \quad \text { média geral } \\
& * * * \text { - coeficiente de variação }
\end{aligned}
$$


Tabela 17 - Resultados da aplicação do Teste Duncan para o caráter nümero de espigas por planta.

$1975 / 76$

1,31
1,2776
1,2632
1,2545
1,2365
1,2344 ||

$1976 / 77$

1,3939
1,3489
1,3085
1,297
1,256 ||$_{1}$

M. G.

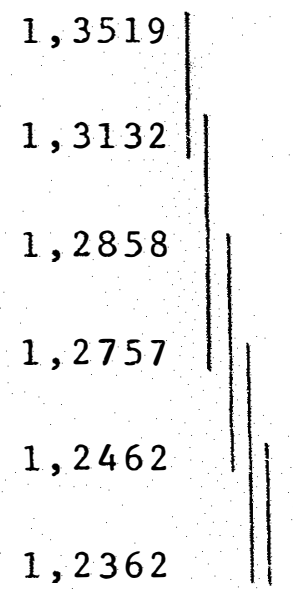


Tabela 18 - Médias nos dois anos de plantio de experimentos em blocos ao acaso, médias gerais e coeficientes de variação para o caráter tipo de pendão.

\begin{tabular}{|c|c|c|c|}
\hline Tratamentos & $1975 / 76$ & $1976 / 77$ & M.G. $* *$ \\
\hline Branca & 2,1573 & 2,459 & 2,3081 \\
\hline Amarela & 2,125 & 2,3589 & 2,2419 \\
\hline Intermediāria & 2,1578 & 2,3915 & 2,2746 \\
\hline Centralmex & 2,0919 & 2,3563 & 2,2241 \\
\hline$A g-152$ & 2,0271 & 2,2991 & 2,1631 \\
\hline HDmd- 7974 & 2,2953 & 2,513 & 2,4041 \\
\hline $\operatorname{CV}(\%)^{* * *}$ & 3,55 & 5,44 & 4,71 \\
\hline
\end{tabular}

$$
\begin{aligned}
& * \quad \text { - dados transformados para } \sqrt{x} \\
& * * \quad \text { média geral } \\
& * * * \text { - coeficiente de variação }
\end{aligned}
$$


Tabela 19 - Resultados da aplicação do Teste Duncan para o caráter tipo de pendão.

\begin{tabular}{l|l}
2,2953 & 2,513 \\
2,1578 \\
2,1573 \\
2,125 \\
2,0919 \\
2,0271
\end{tabular}


Tabela 20 - Médias nos dois anos de plantio de experimentos em blocos ao acaso, médias gerais e coeficientes de variação para o carāter "stand". *

\begin{tabular}{lccc}
\hline Tratamentos & $1975 / 76$ & $1976 / 77$ & M.G. ** \\
Branca & 6,647 & 6,531 & 6,589 \\
Amarela & 6,517 & 6,694 & 6,6055 \\
Intermediäria & 6,355 & 6,674 & 6,5145 \\
Centralmex & 6,515 & 6,647 & 6,581 \\
Ag-152 & 6,593 & 6,739 & 6,666 \\
HDmd-7974 & 5,694 & 6,76 & 6,727 \\
\hline CV (\%) & 5,78 & 4,13 & 5,01 \\
\hline
\end{tabular}

* dados transformados para $\sqrt{x}$

** média geral

*** coeficiente de variação 
Tabela 21 - Resultados da aplicação do Teste Duncan para o carāter "stand".

$1975 / 76 \quad 1976 / 77 \quad$ M.G.

\begin{tabular}{|c|c|c|}
\hline 6,694 & 6,76 & 6,727 \\
\hline 6,647 & 6,739 & 6,666 \\
\hline 6,593 & 6,694 & 6,6055 \\
\hline 6,517 & 6,674 & 6,589 \\
\hline 6,515 & 6,647 & 6,581 \\
\hline 6,355 & 6,531 & 6,5145 \\
\hline
\end{tabular}


Tabela 22 - Médias nos dois anos de plantio de experimentos em blocos ao acaso, mëdias gerais e coeficientes de variação para o caráter acamamento. *

\begin{tabular}{lccc}
\hline Tratamentos & $1975 / 76$ & $1976 / 77$ & M.G. ** \\
\hline Branca & 2,241 & 2,215 & 2,228 \\
Amarela & 2,146 & 2,255 & 2,2005 \\
Intermediäria & 1,962 & 2,245 & 2,1035 \\
Centralmex & 2,569 & 2,641 & 2,605 \\
Ag-152 & 2,198 & 1,838 & 2,018 \\
HDmd- 7974 & 1,881 & 1,934 & 1,9075 \\
\hline CV $(\%) * * *$ & 22,67 & 31,65 & 27,57 \\
\hline
\end{tabular}

$$
\begin{aligned}
& * \text { - dados transformados para } \sqrt{x+0,5} \\
& * * \text { - média geral } \\
& * * * \text { - coeficiente de variação }
\end{aligned}
$$


Tabela 23 - Resultados da aplicação do Teste Duncan para o caráter acamamento.

\begin{tabular}{|c|c|c|}
\hline $1975 / 76$ & $1976 / 77$ & M.G. \\
\hline $2,569 \mid$ & 2,6411 & 2,605 \\
\hline 2,241 & 2,255 & 2,228 \\
\hline 2,198 & 2,245 & 2,2005 \\
\hline 2,146 & $2,215 \|$ & 2,1035 \\
\hline 1,962 & 1,934 & 2,018 \\
\hline 1,881 & 1,838 & 1,9075 \\
\hline
\end{tabular}


Tabela 24 - Médias nos dois anos de plantio de experimentos em blocos ao acaso, médias gerais e coeficientes de variação para o caräter número de filleiras por espiga.

\begin{tabular}{lccc}
\hline Tratamentos & $1975 / 76$ & $1976 / 77$ & M.G.* \\
\hline Branca & 3,542 & 3,5828 & 3,5624 \\
Amarela & 3,5143 & 3,5396 & 3,5269 \\
Intermediäria & 3,5063 & 3,557 & 3,5316 \\
Centralmex & 3,4298 & 3,566 & 3,4979 \\
Ag-152 & 3,5472 & 3,5356 & 3,5414 \\
HDmd-7974 & 3,5078 & 3,5212 & 3,5145 \\
\hline CV (\%) & 2,11 & 1,97 & 2,04 \\
\hline
\end{tabular}

* - dados transformados para $\sqrt{x}$

** - média geral

*** - coeficiente de variação 
Tabela 25 - Resultados da aplicação do Teste Duncan para o caráter número de fileiras por espiga.

\begin{tabular}{|c|c|c|}
\hline $1975 / 76$ & $1976 / 77$ & M. G. \\
\hline 3,54721 & 3,5828 & 3,5624 \\
\hline 3,542 & 3,566 & 3,5414 \\
\hline 3,5143 & 3,557 & 3,5316 \\
\hline 3,5078 & 3,5396 & 3,5269 \\
\hline 3,5063 & 3,5356 & 3,5145 \\
\hline 3,4298 & 3,5212 & 3,4679 \\
\hline
\end{tabular}


Tabela 26 - Médias nos dois anos de plantio de experimentos em blocos ao acaso, médias gerais e coeficientes de variação para o caráter número de grãos por fileira.

\begin{tabular}{lccc}
\hline Tratamentos & $1975 / 76$ & $1976 / 77$ & M.G. ** \\
\hline Branca & 6,088 & 6,0703 & 6,0791 \\
Amarela & 6,1613 & 6,1605 & 6,1609 \\
Intermediária & 6,051 & 6,0757 & 6,0633 \\
Centralmex & 6,0218 & 6,2396 & 6,1307 \\
Ag-152 & 5,9679 & 6,1775 & 6,0727 \\
HDmd-7974 & 6,3059 & 6,3427 & 6,3243 \\
\hline CV $(\%) * * *$ & 4,21 & 3,15 & 3,71 \\
\hline
\end{tabular}

$$
\begin{aligned}
& * \quad \text { - dados transformados para } \sqrt{x} \\
& * * \quad \text { média geral } \\
& * * * \text { - coeficiente de variação }
\end{aligned}
$$


Tabela 27 - Resultados da aplicação do Teste Duncan para o caráter número de grãos por fileira.

M.G.
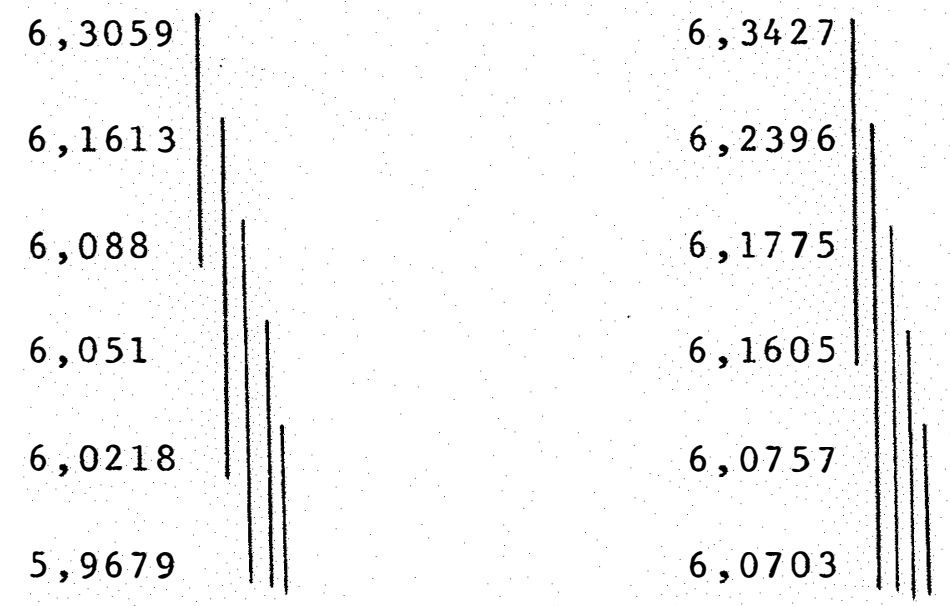

6,3243
6,1609
6,1307
6,0791
6,0727
6,0633


Tabela 28 - Médias nos dois anos de plantio de experimentos em blocos ao acaso, médias gerais e coeficientes de variação para o carāter tamanho da espiga.*

\begin{tabular}{lccc}
\hline Tratamentos & $1975 / 76$ & $1976 / 77$ & N.G. \\
Branca & 17,34 & 17,772 & 17,556 \\
Amarela & 17,242 & 17,434 & 17,338 \\
Intermediária & 17,352 & 17,392 & 17,372 \\
Centralmex & 16,852 & 18,052 & 17,452 \\
Ag-152 & 15,207 & 16,084 & 15,6455 \\
HDmd-7974 & 18,778 & 18,399 & 18,5885 \\
\hline CV (\%) & 4,53 & 4,83 & 4,84 \\
\hline
\end{tabular}

$$
\begin{aligned}
& * \quad \text { medidas em cm } \\
& * * \quad-\text { média geral } \\
& * * * \quad \text { coeficiente de variação }
\end{aligned}
$$


Tabela 29 - Resultados da aplicação do Teste Duncan para o carāter tamanho da espiga.

\begin{tabular}{|c|c|c|}
\hline $1975 / 76$ & $1976 / 77$ & M.G. \\
\hline 18,778 & 18,399 & 18,5885 \\
\hline 17,352 & 18,052 & 17,556 \\
\hline 17,34 & 17,772 & 17,452 \\
\hline 17,242 & 17,434 & 17,372 \\
\hline 16,852 & 17,392 & 17,338 \\
\hline 15,207 & 16,084 & 15,6455 \\
\hline
\end{tabular}


Tabela 30 - Médias nos dois anos de plantio de experimentos em blocos ao acaso, médias gerais e coeficientes de variação para o caráter diâmetro da espiga.*

\begin{tabular}{|c|c|c|c|}
\hline Tratamentos & $1975 / 76$ & $1976 / 77$ & $\mathrm{M}, \mathrm{G} .{ }^{* *}$ \\
\hline Branca & 4,513 & 4,505 & 4,509 \\
\hline Amare 1 a & 4,488 & 4,441 & 4,4645 \\
\hline Intermediària & 4,453 & 4,477 & 4,465 \\
\hline Centralmex & 4,473 & 4,613 & 4,543 \\
\hline $\mathrm{Ag}-152$ & 4,634 & 4,574 & 4,604 \\
\hline HDmd -7974 & 4,016 & 4,05 & 4,033 \\
\hline $\operatorname{CV}(\%)^{* * *}$ & 2,41 & 2,65 & 2,53 \\
\hline
\end{tabular}

$$
\begin{aligned}
& * \quad \text { - medidas em } c m \\
& * * \quad-\text { média geral } \\
& * * * \quad \text { coeficiente de variação }
\end{aligned}
$$


Tabela 31 - Resultados da aplicação do Teste Duncan para o caráter diâmetro da espiga.

\begin{tabular}{l|l}
4,634 & 4,613 \\
4,513 & 4,574 \\
4,453
\end{tabular}|| $\begin{aligned} & 4,505 \\
& 4,016 \\
& 4,477\end{aligned}|| \begin{aligned} & 4,604 \\
& 4,543 \\
& 4,441\end{aligned} \mid$


Tabela 32 - Médias nos dois anos de plantio de experimentos em blocos ao acaso, médias gerais e coeficientes de variação para o caráter peso da espiga.

\begin{tabular}{lccc}
\hline Tratamentos & $1975 / 76$ & $1976 / 77$ & M.G. \\
\hline Branca & 182,421 & 184,058 & 183,2395 \\
Amarela & 182,508 & 178,985 & 180,7465 \\
Intermediária & 178,235 & 181,526 & 179,8805 \\
Centralmex & 174,442 & 204,371 & 189,4065 \\
Ag- 152 & 173,543 & 184,608 & 179,0755 \\
HDmd- 7974 & 159,648 & 165,97 & 162,809 \\
\hline CV $(\%) * * *$ & 9,1 & 9,89 & 9,52 \\
\hline
\end{tabular}

$$
\begin{aligned}
& * \quad \text { - peso em gramas } \\
& * * \quad-\text { média geral } \\
& * * * \text { - coeficiente de variação }
\end{aligned}
$$


Tabela 33 - Resultados da aplicação do Teste Duncan para o caráter peso da espiga.

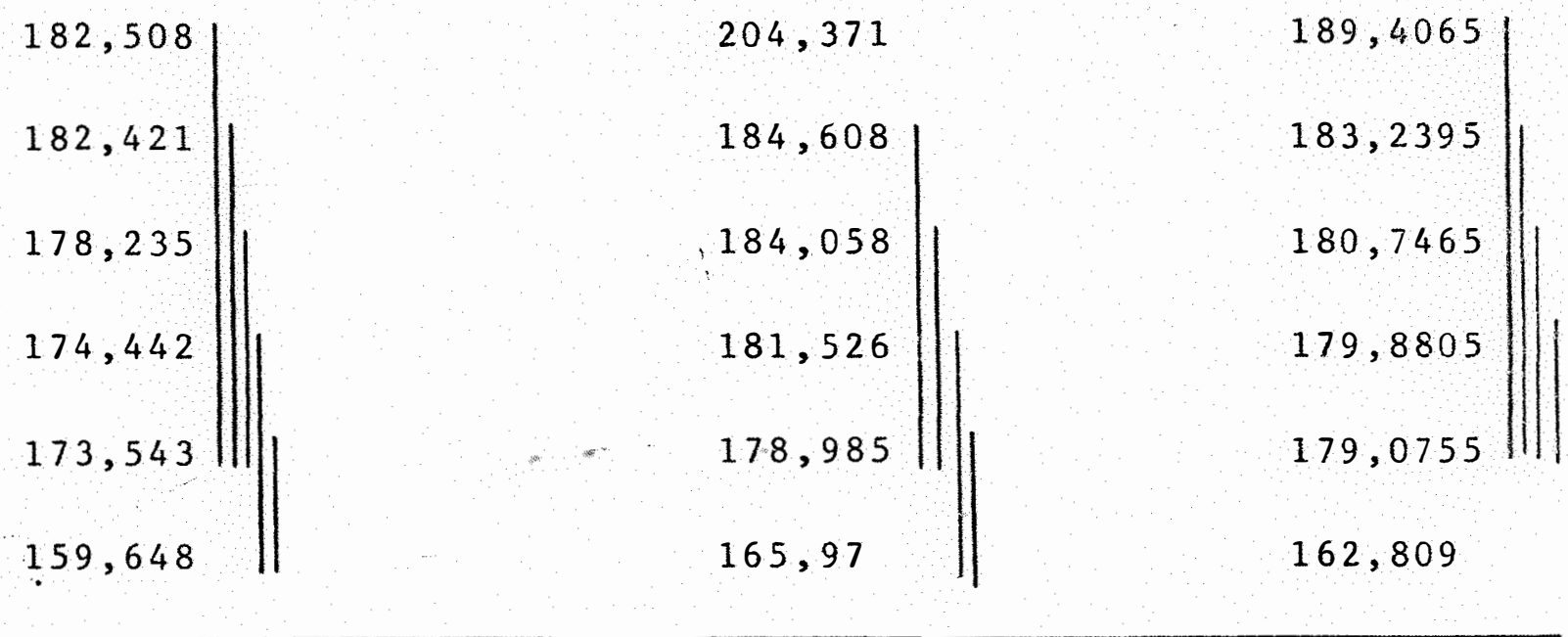


Tabela 34 - Médias nos dois anos de plantio de experimentos em blocos ao acaso, médias gerais e coeficientes de variação para o caráter peso do sabugo.

\begin{tabular}{lccc}
\hline Tratamentos & $1975 / 76$ & $1976 / 77$ & M.G. \\
Branca & 29,327 & 29,816 & 29,57 \\
Amarela & 28,725 & 27,971 & 28,348 \\
Intermediária & 27,846 & 29,789 & 28,8175 \\
Centralmex & 28,326 & 31,538 & 29,932 \\
Ag-152 & 27,288 & 28,633 & 27,9605 \\
HDmd -7974 & 26,65 & 25,251 & 25,9505 \\
\hline CV (\%) ** & 11,11 & 9,37 & 10,25 \\
\hline
\end{tabular}

$$
\begin{aligned}
& * \quad-\text { peso em gramas } \\
& * * \quad-\text { média geral } \\
& * * * \quad \text { coeficiente de variação }
\end{aligned}
$$


Tabela 35 - Resultados da aplicação do Teste Duncan para o caráter peso do sabugo.

M.G.
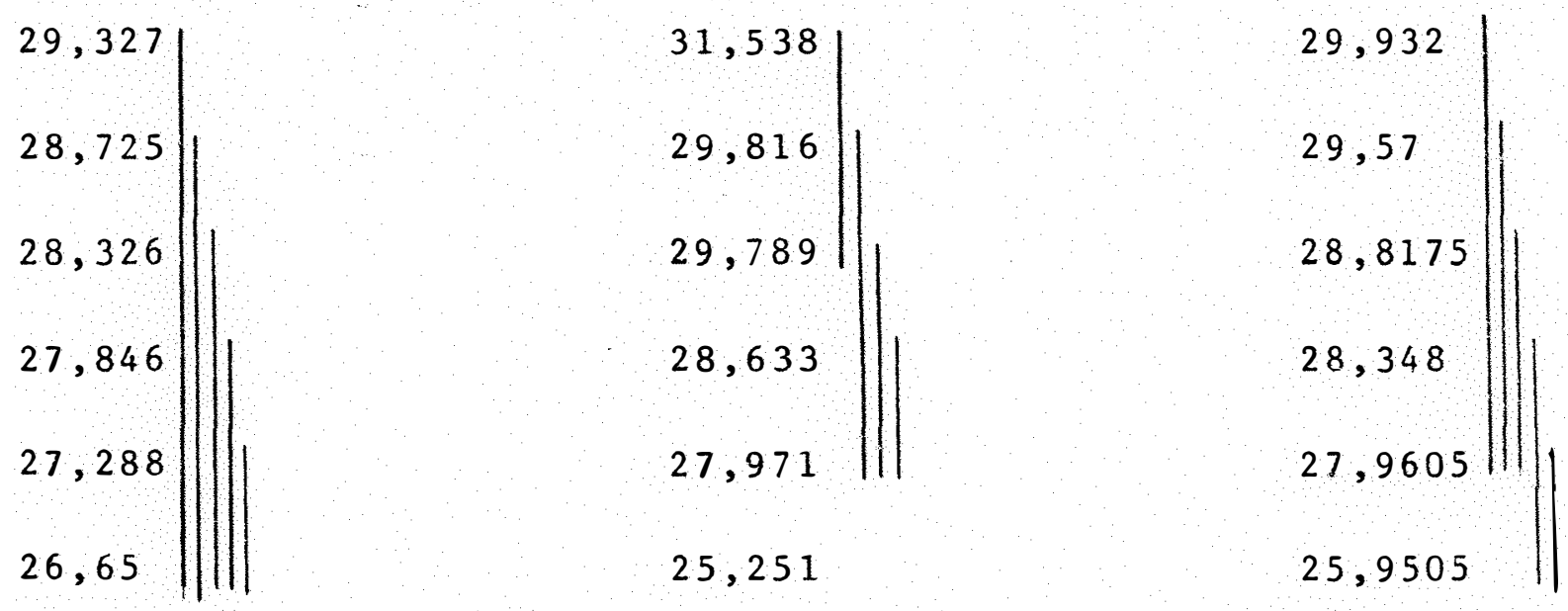
Tabela 36 - Médias nos dois anos de plantio de experimentos em blocos ao acaso, médias gerais e coeficientes de va riação para o caräter peso de 100 grãos ${ }^{*}$.

\begin{tabular}{lccc}
\hline Tratamentos & $1975 / 76$ & $1976 / 77$ & $M^{* *}$ \\
\hline Branca & 33,65 & 34,06 & 33,855 \\
Amarela & 34,41 & 32,47 & 33,44 \\
Intermediäria & 33,6 & 34,1 & 33,85 \\
Centralmex & 35,52 & 35,58 & 35,55 \\
Ag-152 & 32,4 & 32,7 & 32,55 \\
HDmd- 7974 & 28,89 & 29,03 & 28,96 \\
\hline CV (\%) & 9,61 & 6,84 & 84 \\
\hline
\end{tabular}

$$
\begin{aligned}
& * \quad \text { peso em gramas } \\
& \star * \quad \text { média geral } \\
& \star * * \quad \text { coeficiente de variação }
\end{aligned}
$$


Tabela 37 - Resultados da aplicação do Teste Duncan para o ca ráter peso de 100 grãos.

$1975 / 76$

35,52
34,41
33,65
33,6
32,4 ||

28,89
$1976 / 77$

$\left.\begin{aligned} & 35,58 \\ & 34,1 \\ & 34,06 \\ & 32,7 \\ & 32,47\end{aligned}\right|_{\mid}$

29,03
M. G.

$\begin{aligned} & 35,55 \\ & 33,855 \\ & 33,85 \\ & 33,44 \\ & 32,55\end{aligned} \mid$


Tabela 38 - Médias nos dois anos de plantio de experimentos em blocos ao acaso, médias gerais e coeficientes de variação para o caráter nümero médio de grãos por espiga*.

\begin{tabular}{lccc}
\hline Tratamentos & $1975 / 76$ & $1976 / 77$ & M.G. $^{* *}$ \\
\hline Branca & 21,7058 & 21,6976 & 21,7017 \\
Amarela & 21,637 & 21,8254 & 21,7312 \\
Intermediäria & 21,2549 & 21,5874 & 21,4211 \\
Centralmex & 20,7975 & 22,2319 & 21,5147 \\
Ag-152 & 21,2114 & 21,8865 & 21,5489 \\
HDmd-7974 & 22,1609 & 22,3761 & 22,2685 \\
\hline CV (\%) & 4,49 & 3,95 & 4,22 \\
\hline
\end{tabular}

$$
\begin{aligned}
& \text { * - dados transformados para } \sqrt{x} \\
& * * \text { - média geral } \\
& * * * \text { - coeficiente de variação }
\end{aligned}
$$


.147 .

Tabela 39 - Resultados da aplicação do Teste Duncan para o caráter número médio de grãos por espiga.

\begin{tabular}{|c|c|c|}
\hline $1975 / 76$ & $1976 / 77$ & M.G. \\
\hline 22,1609 & 22,3761 & 22,2685 \\
\hline 21,7058 & 22,2319 & 21,7312 \\
\hline 21,637 & 21,8865 & 21,7017 \\
\hline 21,2549 & 21,8254 & 21,5489 \\
\hline 21,2114 & 21,6976 & 21,5147 \\
\hline 20,7975 & 21,5874 & 21,4211 \\
\hline
\end{tabular}


Tabela 40 - Médias nos dois anos de plantio de experimentos em blocos ao acaso, médias gerais e coeficientes de variação para o caráter produção média por planta*.

\begin{tabular}{lccc}
\hline Tratamentos & $1975 / 76$ & $1976 / 77$ & M.G.** \\
\hline Branca & 116,812 & 138,1372 & 127,4748 \\
Amare 1 a & 125,664 & 125,9168 & 125,7904 \\
Intermediäria & 131,794 & 128,9959 & 130,3952 \\
Centralmex & 129,536 & 150,4806 & 140,0081 \\
Ag- 152 & 117,982 & 144,1757 & 131,0789 \\
HDmd- 7974 & 125,816 & 127,2116 & 126,5139 \\
\hline CV (\%) & 21,24 & 22,65 & 22,04 \\
\hline
\end{tabular}

* - peso em gramas

* - média gera 1

*** - coeficiente de variação 
.149 .

Tabela 41 - Resultados da aplicação do Teste Duncan para o caráter produção média por planta.

\begin{tabular}{|c|c|c|}
\hline $1975 / 76$ & $1976 / 77$ & M.G. \\
\hline 131,794 & 150,4806 & 140,0081 \\
\hline 129,536 & 144,1757 & 131,0789 \\
\hline 125,816 & 138,1372 & 130,3952 \\
\hline 125,664 & 128,9959 & 127,4748 \\
\hline 117,982 & 127,2116 & 126,5139 \\
\hline 116,812 & 125,9168 & 125,7904 \\
\hline
\end{tabular}


Tabela 42 - Médias nos dois anos de plantio de experimentos em blocos ao acaso, médias gerais e coeficientes de variação para o caráter número de espigas por par$\operatorname{cel} a^{*}$.

\begin{tabular}{lccc}
\hline Tratamentos & $1975 / 76$ & $1976 / 77$ & M. . * \\
\hline Branca & 5,637 & 6,7681 & 6,2024 \\
Amarela : & 5,9 & 6,7952 & 6,3478 \\
Intermediária & 5,748 & 6,7312 & 6,2394 \\
Centralmex & 5,968 & 6,5683 & 6,2685 \\
Ag- 152 & 5,872 & 6,7319 & 6,302 \\
HDmd- 7974 & 6,504 & 7,1051 & 6,8043 \\
\hline CV (\%) & 6,48 & 7,41 & 6,99 \\
\hline
\end{tabular}

$$
\begin{aligned}
& \text { * - dados transformados para } \sqrt{x} \\
& * * \quad \text { média geral } \\
& * * * \text { - coeficiente de variação }
\end{aligned}
$$


.151 .

Tabela 43 - Resultados da aplicação do Teste Duncan para o caráter número de espigas por parcela.

M.G.

\begin{tabular}{|c|c|c|}
\hline 6,504 & 7,1051 & 6,8043 \\
\hline 5,967 & 6,7952 & 6,3478 \\
\hline 5,9 & 6,7681 & 6,302 \\
\hline 5,872 & 6,7319 & 6,2685 \\
\hline 5,748 & 6,7312 & 6,2394 \\
\hline 5,637 & 6,5683 & 6,2024 \\
\hline
\end{tabular}


Tabela 44 - Médias nos dois anos de plantio de experimentos em blocos ao acaso, médias gerais e coeficientes de variação para o caráter peso médio do grão*.

\begin{tabular}{lccc}
\hline Tratamentos & $1975 / 76$ & $1976 / 77$ & M.G. \\
\hline Branca & 0,319 & 0,3224 & 0,3207 \\
Amarela & 0,3263 & 0,3143 & 0,3203 \\
Intermediäria & 0,3259 & 0,3225 & 0,3242 \\
Centralmex & 0,3356 & 0,3467 & 0,3412 \\
Ag- 152 & 0,3202 & 0,3224 & 0,3213 \\
HD-md-7974 & 0,2687 & 0,282 & 0,2753 \\
\hline CV (\%) & & & 7,06 \\
\hline
\end{tabular}

* - peso em gramas

** - média geral

*** - coeficiente de variação 
Tabela 45 - Resultados da aplicação do Teste Duncan para o caráter peso médio do grão.

0,3356
0,3263
0,3259
0,3202
0,319 ||$_{0}$

$$
0,3467
$$

0,3225

0,3242

0,3224

0,3213

0,3224

0,3207

0,3143

0,3203

0,282

0,2753 
Tabela 46 - Médias nos dois anos de plantio de experimentos em blocos ao acaso, médias gerais e coeficientes de variação para o carāter comprimento do grão*.

\begin{tabular}{lccc}
\hline Tratamentos & $1975 / 76$ & $1976 / 77$ & M.G.* \\
\hline Branca & 1,1848 & 1,2326 & 1,2087 \\
Amarela & 1,1914 & 1,2244 & 1,2079 \\
Intermediária & 1,1714 & 1,2054 & 1,1884 \\
Centralmex & 1,1786 & 1,2528 & 1,2157 \\
Ag- 152 & 1,1804 & 1,2154 & 1,1979 \\
HDmd- 7974 & 1,0576 & 1,12 & 1,0888 \\
\hline CV (\%) & 3,22 & 3,51 & 3,38 \\
\hline
\end{tabular}

$$
\begin{aligned}
& \text { * - medidas em cm } \\
& * * \quad \text { média geral } \\
& * * * \text { - coeficiente de variação }
\end{aligned}
$$


Tabela 47 - Resultados da aplicação do Teste Duncan para o caráter comprimento do grão.

M. G .

\begin{tabular}{|c|c|c|}
\hline 1,1914 & 1,2528 & 1,2157 \\
\hline 1,1848 & 1,2326 & 1,2087 \\
\hline 1,1804 & 1,2244 & 1,2079 \\
\hline 1,1786 & 1,2154 & 1,1979 \\
\hline 1,1714 & 1,2054 & 1,1884 \\
\hline 1,0576 & 1,12 & 1,0888 \\
\hline
\end{tabular}


Tabela 48 - Médias nos dois anos de plantio de experimentos em blocos ao acaso, médias gerais e coeficientes de variação para o caráter largura do grão*.

\begin{tabular}{lccc}
\hline Tratamentos & $1975 / 76$ & $1976 / 77$ & M.G.* \\
\hline Branca & 0,9826 & 0,9714 & 0,977 \\
Amarela & 0,9818 & 0,9656 & 0,9737 \\
Intermediäria & 0,9798 & 0,9794 & 0,9796 \\
Centralmex & 1,0156 & 0,9824 & 0,999 \\
Ag-152 & 0,9928 & 0,9758 & 0,9843 \\
HDmd-7974 & 0,918 & 0,9058 & 0,9119 \\
\hline CV (\%) & $2,7 *$ & 2,94 & 2,72 \\
\hline
\end{tabular}

$$
\begin{aligned}
& \text { * - medidas em cm } \\
& \text { ** - média geral } \\
& \text { ** - coeficiente de variação }
\end{aligned}
$$


Tabela 49 - Resultados da aplicação do Teste Duncan para o caräter largura do grão.

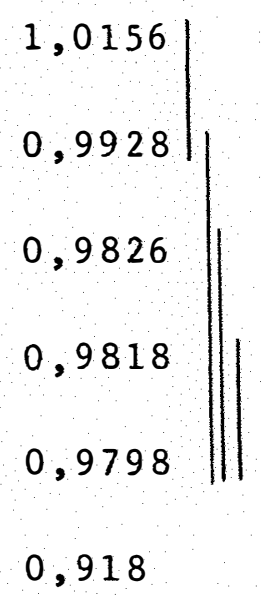

0,9824
0,9794
0,9758
0,9714
0,9656

0,9058

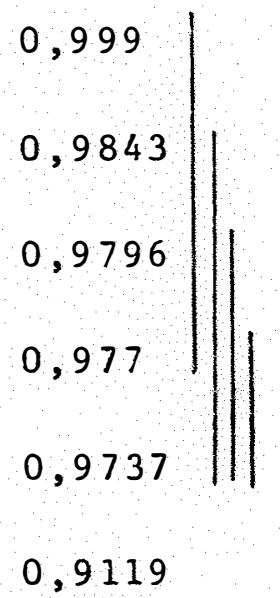


Tabela 50 - Médias nos dois anos de plantio de experimentos em blocos ao acaso, médias gerais e coeficientes de variação para o caráter espessura do grão*.

\begin{tabular}{lccc}
\hline Tratamentos & $1975 / 76$ & $1976 / 77$ & $M^{*} *^{*}$ \\
\hline Branca & 0,4164 & 0,4092 & 0,4128 \\
Amarela & 0,413 & 0,4 & 0,4065 \\
Intermediária & 0,421 & 0,4098 & 0,4154 \\
Centralmex & 0,4148 & 0,4094 & 0,4121 \\
Ag-152 & 0,4056 & 0,4016 & 0,4036 \\
HDmd- 7974 & 0,415 & 0,4032 & 0,4091 \\
\hline CV $(\%) * * *$ & 4,75 & 3,25 & 4,15 \\
\hline
\end{tabular}

$$
\begin{aligned}
& * \quad \text { - medidas em cm } \\
& * * \quad-\text { média geral } \\
& * * * \quad \text { coeficiente de variação }
\end{aligned}
$$


Tabela 51 - Resultados da aplicação do Teste Duncan para o caráter espessura do grão.

M. G.

$\begin{aligned} & 0,421 \\ & 0,4164 \\ & 0,415 \\ & 0,4148 \\ & 0,413 \\ & 0,4056\end{aligned} \mid$

$\begin{aligned} & 0,4098 \\ & 0,4094 \\ & 0,4092 \\ & 0,4032 \\ & 0,4016 \\ & 0,4\end{aligned} \mid$

0,4154
0,4128
0,4121
0,4091
0,4065
0,4036

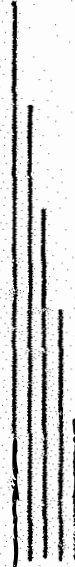


Tabela 52 - Médias, Teste Duncan e coeficiente de variação para o caráter época de florescimento.

\begin{tabular}{lrr}
\hline Tratamentos & Médias & Teste Duncan \\
\hline Branca & 8,7456 & 8,7457 \\
& 8,7456 \\
Amarela & 8,7344 & 8,7345 \\
& 8,7344
\end{tabular}

OBS.: dados transformados para $\sqrt{x}$ 
Tabela 53 - Médias, coeficiente de variação e Teste Duncan para a la. contagem do teste padrão de germinação.

\begin{tabular}{ccc} 
Tratamentos & Médias & Teste Duncan \\
\hline Branca & 69,675 & 74,1825 \\
Amarela & 71,965 \\
Intermediária & 64,7825 & 71,285 \\
Centralmex & 59,375 & 69,675
\end{tabular}$\|$

OBS.: dados transformados para arc sen $\sqrt{\%}$ 
Tabela 54 - Médias, coeficiente de variação e Teste Duncan pä ra o teste padrão de germinação.

\begin{tabular}{|c|c|c|}
\hline Tratamentos & Médias & Teste Duncan \\
\hline \multirow[t]{2}{*}{$\mathrm{Branca}$} & 78,54 & 85,935 \\
\hline & & 85,935 \\
\hline \multirow[t]{2}{*}{ Amarela } & 70,055 & 81,5375 \\
\hline & & 78,54 \\
\hline \multirow[t]{2}{*}{ Intermediāria } & 69,415 & 70,055 \\
\hline & & 69,415 \\
\hline Centralmex & 85,935 & - \\
\hline $\mathrm{Ag}-152$ & 81,5375 & \\
\hline HDmd- 7974 & 85,935 & \\
\hline $\operatorname{cV}(\%)$ & 6,15 & \\
\hline
\end{tabular}

OBS.: dados transformados para arc sen $\sqrt{\%}$ 
Tabela 55 - Médias, coeficiente de variação e Teste Duncan para o teste de envel hecimento rápido.

Branca

Amare la

Intermediāria

Centralmex

Ag- 152

HDmd- 7974

CV (\%)
65,7375

53,56

48,1825

?

70,7225

74,35

73,8925

$$
\begin{aligned}
& 74,35 \\
& 73,8925 \\
& 70,7225 \\
& 65,7575
\end{aligned}
$$

$$
\begin{aligned}
& 53,56 \\
& 48,1825
\end{aligned}
$$

$$
6,46
$$

OBS.: dados transformados para arc sen $\sqrt{\%}$ 
Tabela 56 - Médias, coeficiente de variação e Teste Duncan pa$r a$ a velocidade de emergência.

\begin{tabular}{|c|c|c|}
\hline Tratamentos & Médias & Teste Duncan \\
\hline \multirow[t]{2}{*}{ Branca } & 3,2228 & 3,2749 \\
\hline & & 3,2587 \\
\hline \multirow[t]{2}{*}{ Amare $1 \mathrm{a}$} & 3,0649 & 3,2228 \\
\hline & & $3,2136 \|$ \\
\hline \multirow[t]{2}{*}{ Intermediária } & 2,9628 & 3,0649 \\
\hline & & 2,9628 \\
\hline Centralmex & 3,2136 & \\
\hline$A g-152$ & 3,2587 & \\
\hline HDmd- 7974 & 3,2749 & \\
\hline $\mathrm{CV} \quad(\%)$ & 2,3 & \\
\hline
\end{tabular}

OBS.: dados transformados para $\sqrt{x}$ 
Tabela 57 - Médias, coeficiente de variação e Teste Duncan para o "stand" final do teste de emergência no campo.

Centralmex

$\mathrm{Ag}-152$

HDmd- 7974
Branca

Amare 1 a

71,385

68,0525

Intermediāria
71,385

68,0525

79,355

79,2925

83,9025
82,1975

$$
\begin{aligned}
& 83,9025 \\
& 82,1975 \\
& 79,355 \\
& 79,2925
\end{aligned}
$$

CV (\%)

6,81

OBS.: dados transformados para arc sen $\sqrt{\%}$ 
Tabela 58 - Médias, coeficiente de variação e Teste Duncan para o caráter peso total da planta aos 28 dias de idade.

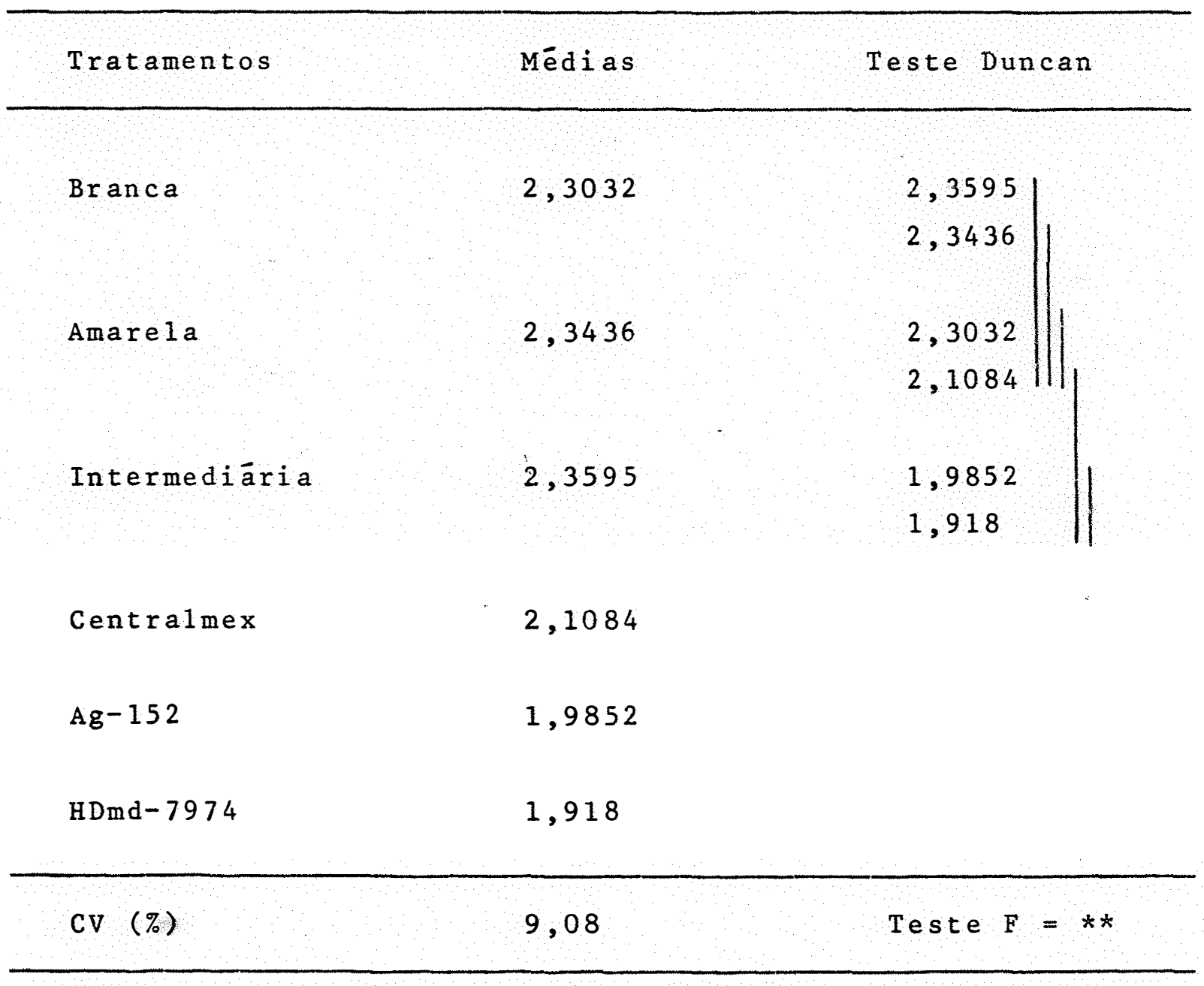

OBS.: dados transformados para $\sqrt{x+0,5}$ 
Tabela 59 - Médias, coeficiente de variação e Teste Duncan para o caráter peso total de raízes.

\begin{tabular}{|c|c|c|}
\hline Tratamentos & Médias & Teste Duncan \\
\hline Branca & 1,7464 & $\begin{array}{l}1,861 \\
1,8296\end{array}$ \\
\hline Amarela & 1,8296 & $\begin{array}{l}1,7464 \\
1,6988\end{array}$ \\
\hline Intermediāria & 1,861 & $\begin{array}{c}1,5868 \\
1,5384\end{array}|U| \mid$ \\
\hline Centralmex & 1,6988 & \\
\hline $\mathrm{Ag}-152$ & 1,5868 & \\
\hline HDmd- 7974 & 1,5384 & \\
\hline CV $(\%)$ & 14,21 & Teste $\mathrm{F}=\mathrm{ns}$ \\
\hline
\end{tabular}

OBS.: dados transformados para $\sqrt{x+0,5}$ 
.168 .

Tabela 60 - Médias, coeficiente de variação e Teste Duncan para o caräter peso de raízes nodais.

Branca

1,3504

Amare 1 a

1,4248

Intermediária

1,455

1,344

1,2752

1,1404

HDind -7974

14,94

Teste $F=n s$

OBS.: dados transformados para $\sqrt{x+0,5}$ 
Tabela 61 - Médias, coeficiente de variação e Teste Duncan para o caráter peso de raízes seminais.

Branca

1,3116

1,354
1,3364

Amarela

1,3364

1,3116

1,2696

Intermediária

1,354

1,2516

1,1664

Centralmex

1,2516

Ag- 152

1,1664

HDmd -7974

1,2696

$\mathrm{CV}(\%)$

10,61

Teste $F=n s$

OBS.: dados transformados para $\sqrt{x+0,5}$ 
Tabela 62 - Médias, coeficiente de variação e Teste Duncan para o caráter número de raízes nodais.

Tratamentos

Branca

Amare la

Intermediāria

3,1615

3,25

3,0432

Centralmex

$\mathrm{Ag}-152$

HDmd -7974

3,1424

2,902
Teste Duncan

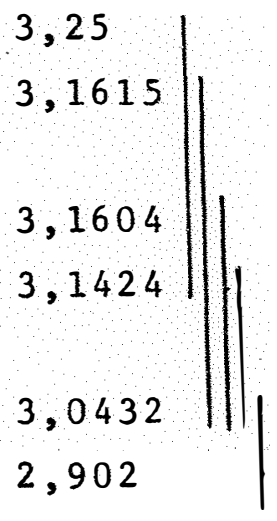

$\mathrm{CV}(\%)$

3,5

Teste $F=* *$

OBS.: dados transformados para $\sqrt{x}$ 
Tabela 63 - Médias, coeficiente de variação e Teste Duncan para o caráter número de raízes seminais.

\begin{tabular}{|c|c|c|}
\hline Tratamentos & Médias & Teste Duncan \\
\hline & & \\
\hline \multirow[t]{2}{*}{ Branca } & 2,3044 & 2,3116 \\
\hline & & 2,3044 \\
\hline Amarela & 2,2356 & 2,284 \\
\hline 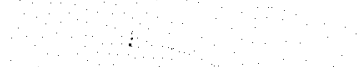 & & 2,2356 \\
\hline \multirow[t]{2}{*}{ Intermediāria } & 2,284 & 2,134 \\
\hline & & $2,1296\|\|$ \\
\hline Centralmex & 2,3116 & \\
\hline$A g-152$ & 2,134 & \\
\hline $\mathrm{HDmd}-7974$ & 2,1296 & \\
\hline $\mathrm{CV} \quad(\%)$ & 7,07 & Teste $F=n s$ \\
\hline
\end{tabular}

OBS.: dados transformados para $\sqrt{x}$ 
Tabela 64 - Médias, coeficiente de variação e Teste Duncan para o caráter número total de raízes.

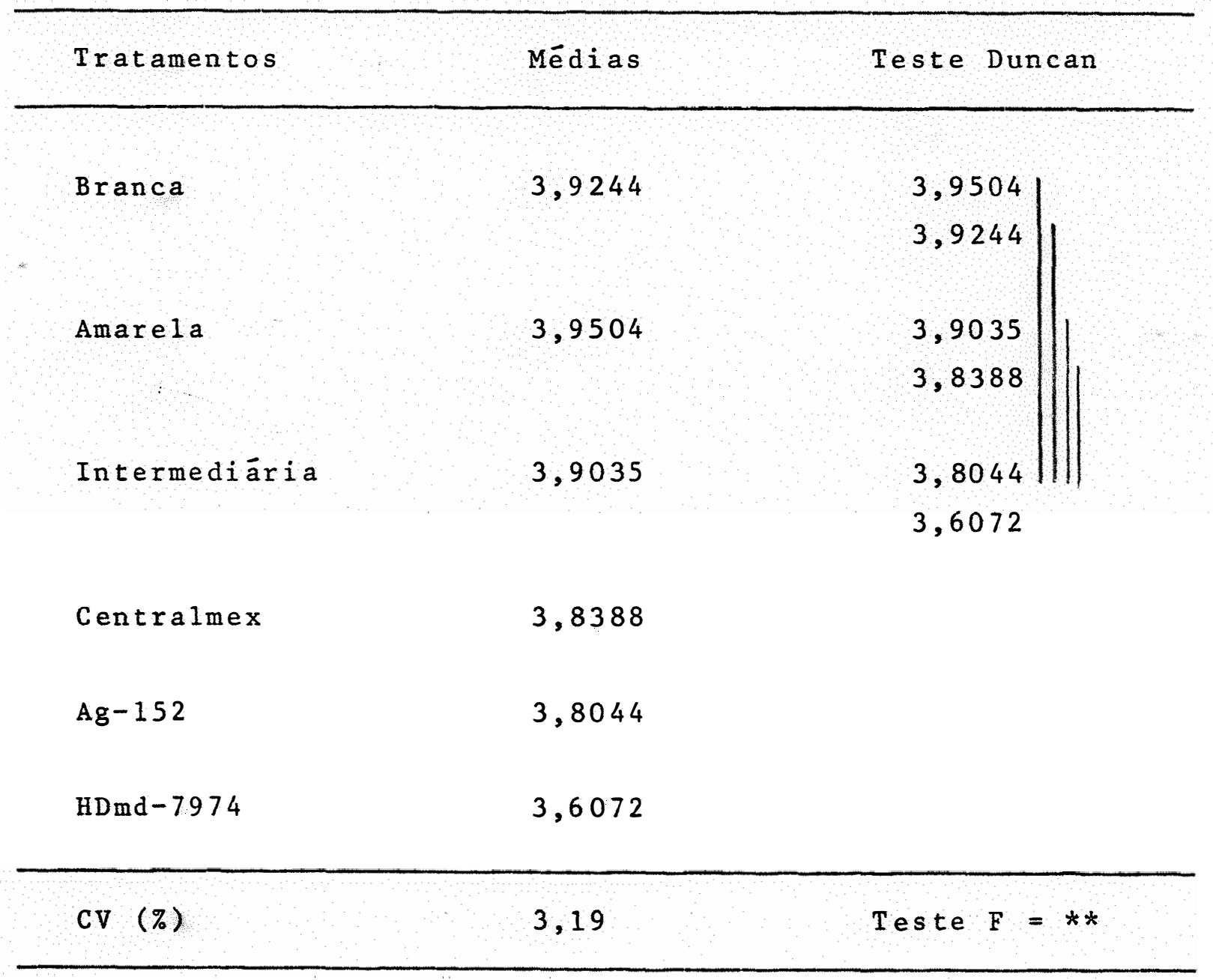

OBS.: dados transformados para $\sqrt{x}$ 
Tabela 65 - Médias, coeficiente de variação e Teste Duncan para o caráter porcentagem de raízes seminais.

Tratamentos

Branca

Amarela

Intermediāria

Centralmex

$A g-152$

HDmd - 7974
Médias

36,1948

34,5044

35,345

$\therefore$

37,1468

34,1552

36,2152
Teste Duncan

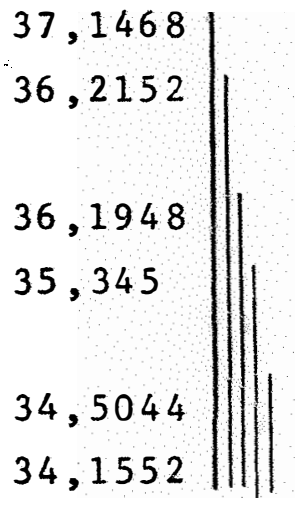


Tabela 66 - Comportamento das três populações do composto em relação aos caracteres determinados e testes de vi gor realizados.

\begin{tabular}{|c|c|c|c|}
\hline Caracteres & B & A & I \\
\hline Produção & - & $i$ & s \\
\hline Produção sem correção & s & - & i \\
\hline Altura da planta & s & - & i \\
\hline Altura da espiga & $\mathrm{s}$ & $i$ & - \\
\hline No de folhas/planta & s & i & - \\
\hline No de espigas/planta & s & $i$ & - \\
\hline Tipo de pendão & s & $i$ & - \\
\hline "Stand" & - & $s$ & $i$ \\
\hline Acamamento & s & - & $i$ \\
\hline No de fileiras/espiga & s & $i$ & - \\
\hline No de grãos/fileira & - & $s$ & i \\
\hline Tamanho da espiga & s & $i$ & - \\
\hline Diâmetro da espiga & s & i & - \\
\hline
\end{tabular}

$$
\begin{aligned}
& B=\text { branca } \\
& I=\text { intermediāria } \\
& A=\text { amarela } \\
& i=\text { inferior } \\
& s=\text { superior }
\end{aligned}
$$

OBS.: Estão assinalados apenas os resultados superiores apresentados por cada população, sem considerar se essa superioridade é vantajosa ou não. Por exemplo: Pop. Branca apresentou maior indice de acamamento, entretanto,es te resultado não é vantajoso. 
Tabela 67 - Comportamento das três populações do composto em relação aos caracteres determinados e testes de ví gor realizados.

$$
\begin{aligned}
& \text { Peso da espiga } \\
& \text { Peso do sabugo } \\
& \text { Peso de } 100 \text { grãos } \\
& \text { No médio de grãos/espiga } \\
& \text { Produção média/planta } \\
& \text { No de espigas/parcela } \\
& \text { Peso médio do grão } \\
& \text { Comprimento do grão } \\
& \text { Largura do grão } \\
& \text { Espessura do grão } \\
& \text { Epoca de florescimento } \\
& \text { la. contagem do TPG } \\
& \text { Teste padrão de germinação } \\
& \text { B = branca } \\
& \text { I = intermediária } \\
& \text { A = amarela } \\
& \text { I = inferior } \\
& S=\text { superior }
\end{aligned}
$$$$
\text { Epoca de florescimento }
$$

$\begin{array}{llr}s & - & i \\ s & i & - \\ s & i & - \\ - & s & i \\ - & i & s \\ i & s & - \\ - & 1 & s \\ s & - & 1 \\ - & i & s \\ - & 1 & s \\ s & i & - \\ s & - & i \\ s & - & i\end{array}$

OBS.: Estão assinalados apenas os resultados superiores apresentados por cada população, sem considerar se essa superioridade é vantajosa ou não. 
Tabela 68 - Comportamento das três populações do composto em relação aos caracteres determinados e testes de vigor realizados.

A

Envelhecimento räpido

Velocidade de emergência

"Stand" final da VE

Peso total da planta

Peso total de raízes

Peso de raízes nodais

Peso de raízes seminais

No de raízes nodais

No de raízes seminais

No total de raízes

\% de raízes seminais

$\begin{array}{lll}s & - & i \\ s & - & i \\ s & - & i \\ i & - & s \\ i & - & s \\ i & - & s \\ i & - & s \\ i & s & - \\ s & i & - \\ - & s & i \\ s & i & -\end{array}$

$B=$ branca

$I=$ intermediāria

$A=$ amarela

$i=$ inferior

$s$ = superior

OBS.: Estão assinalados apenas os resultados superiores apresentados por cada população, sem considerar se essa superioridade é vantajosa ou não. 